\title{
United Kingdom: 2009 Article IV Consultation-Staff Report; Staff Statement; Public Information Notice on the Executive Board Discussion; and Statement by the Executive Director for United Kingdom
}

Under Article IV of the IMF's Articles of Agreement, the IMF holds bilateral discussions with members, usually every year. In the context of the 2009 Article IV consultation with the United Kingdom, the following documents have been released and are included in this package:

- $\quad$ The staff report for the 2009 Article IV consultation, prepared by a staff team of the IMF, following discussions that ended on May 20, 2009, with the officials of the United Kingdom on economic developments and policies. Based on information available at the time of these discussions, the staff report was completed on June 23, 2009. The views expressed in the staff report are those of the staff team and do not necessarily reflect the views of the Executive Board of the IMF.

- $\quad$ A staff statement of July 10, 2009, updating information on recent developments.

- $\quad$ A Public Information Notice (PIN) summarizing the views of the Executive Board as expressed during its July 10, 2009, discussion of the staff report that concluded the Article IV consultation.

- A statement by the Executive Director for the United Kingdom.

The policy of publication of staff reports and other documents allows for the deletion of market-sensitive information.

\author{
Copies of this report are available to the public from \\ International Monetary Fund • Publication Services \\ $70019^{\text {th }}$ Street, N.W. • Washington, D.C. 20431 \\ Telephone: (202) 623-7430 • Telefax: (202) 623-7201 \\ E-mail: publications@imf.org • Internet: http://www.imf.org
}

\section{International Monetary Fund Washington, D.C.}





\section{INTERNATIONAL MONETARY FUND}

\section{UNITED KINGDOM}

\section{Staff Report for the 2009 Article IV Consultation}

Prepared by the Staff Representatives for the 2009 Consultation with the United Kingdom (In consultation with other Departments)

Approved by Marek Belka and Tamim Bayoumi

June 23, 2009

- This report is based on discussions held in London during May 7-20. The team comprised Mr. Chopra (head), Ms. Iakova, Messrs. Meier and Tang (all EUR), Mr. Bornhorst (FAD), and Mr. Moore (MCM).

- $\quad$ The mission met with Chancellor Darling, Bank of England (BoE) Governor King, the Financial Services Authority (FSA) Chairman Turner, and other senior officials, academics, think tanks, and private sector representatives.

- $\quad$ The mission's concluding statement was published on May 20, 2009 and can be found at: http://www.imf.org/external/np/ms/2009/052009a.htm

- $\quad$ Context of past surveillance. In recent years, the Fund and the authorities agreed on the broad policy priorities - maintaining confidence in the UK's fiscal and monetary policy frameworks and enhancing financial sector stability. Given concerns about growing imbalances in the economy, the Fund has advocated strong fiscal discipline to improve resilience to shocks. In the event, the unfolding financial crisis has tested the UK's policy frameworks much more severely than had been anticipated. The authorities' policy response to the crisis has incorporated key elements of Fund advice from the 2008 Art. IV consultation, notably the need to strengthen bank capital and the creation of a special resolution framework.

- $\quad$ The sterling exchange rate is market determined. The United Kingdom has accepted the obligations of Article VIII. The exchange system is free of restrictions on current international transactions, with the exceptions of those notified to the Fund in accordance with Executive Board Decision 144 and UN-sanctioned restrictions on external payments for security reasons.

- It is proposed that the next Article IV consultation be held on the standard 12month cycle. 


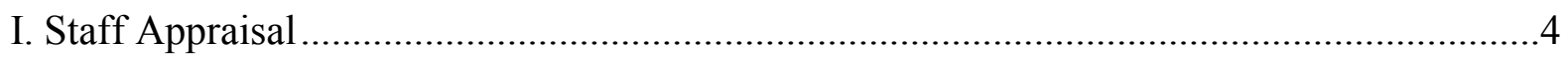

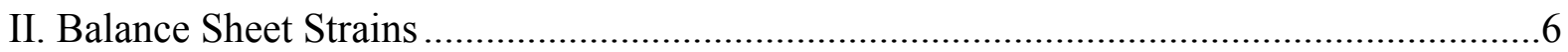

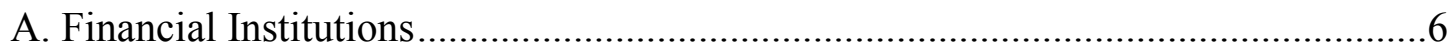

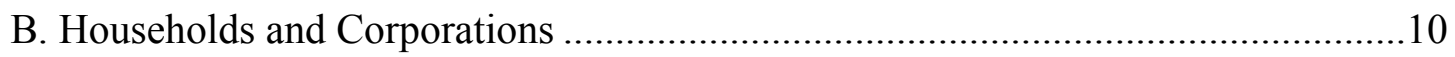

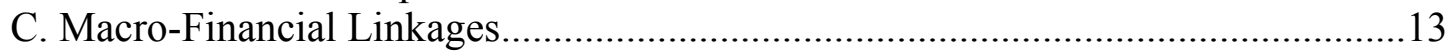

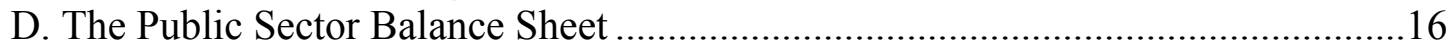

E. Sterling and the UK External Position ............................................................ 19

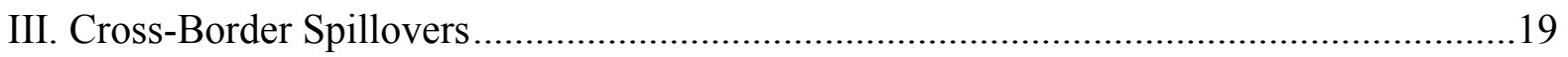

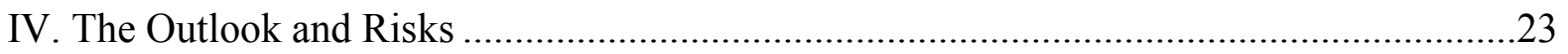

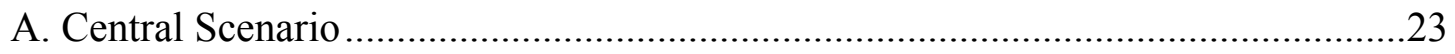

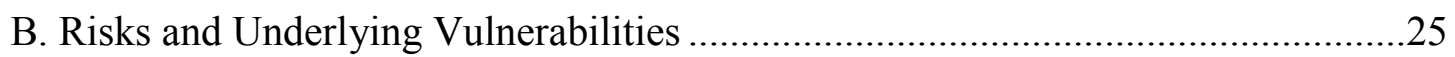

V. Repairing the Financial System ............................................................................26

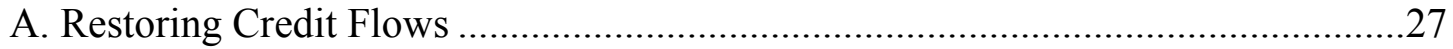

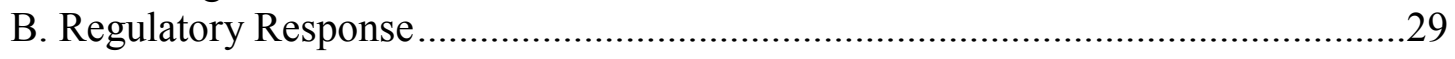

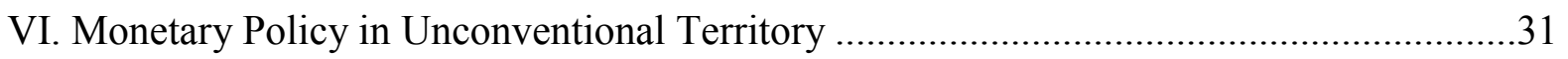

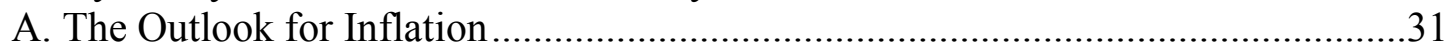

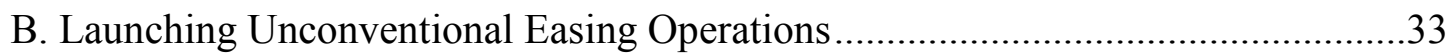

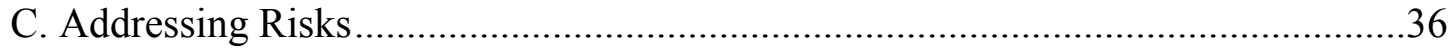

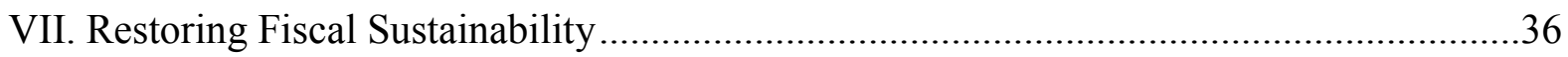

Figures

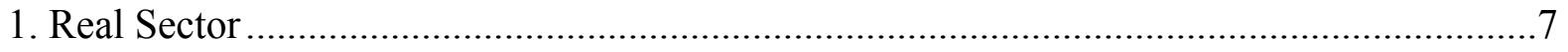

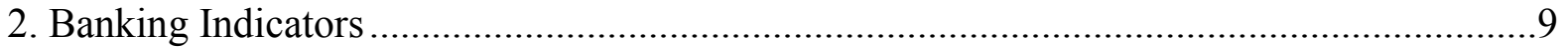

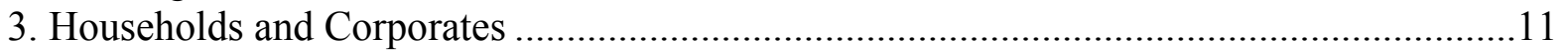

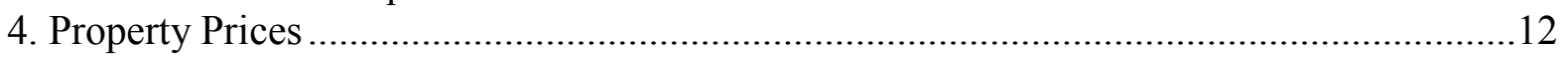

5. Credit and Capital Market Developments.................................................................... 14

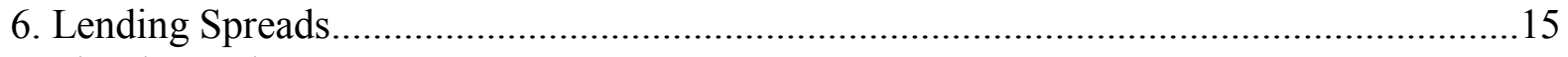

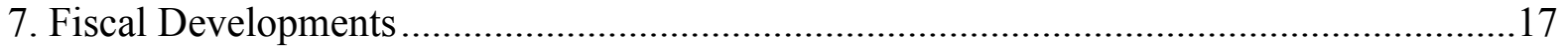

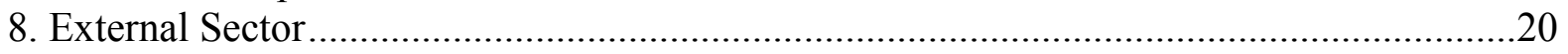

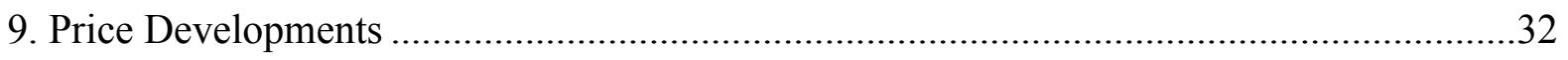

Boxes

1. Potential Spillovers from the UK Financial System to the Rest of the World ..................22

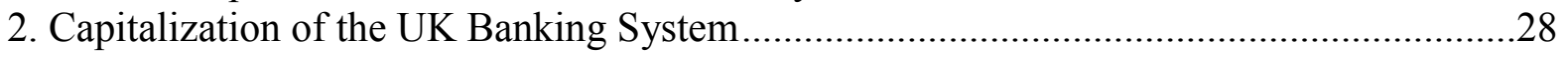

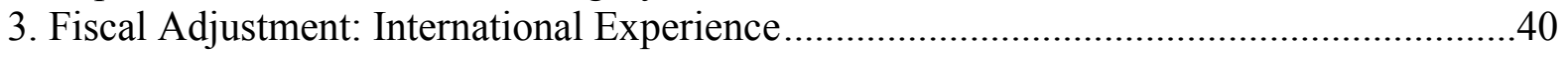

Tables

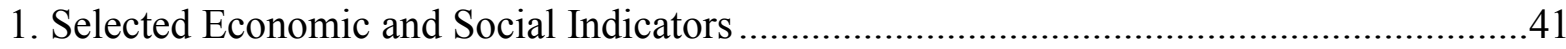

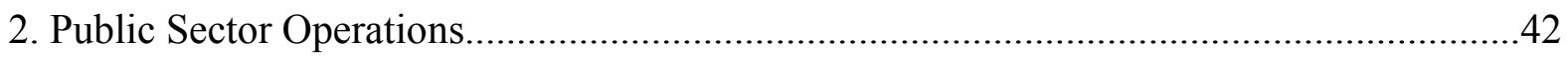


3. Balance of Payments .43

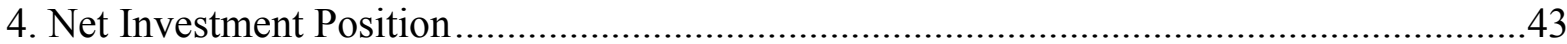

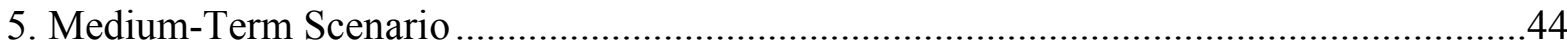

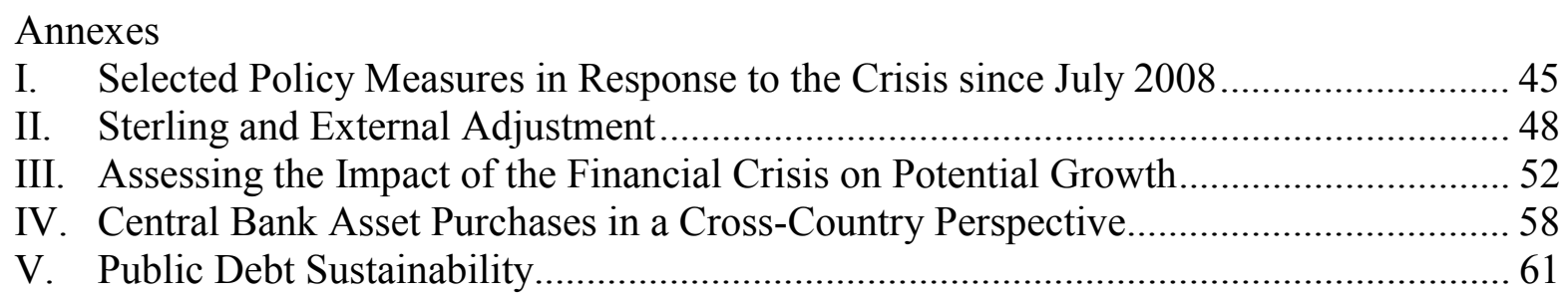




\section{StAfF Appraisal}

1. The United Kingdom has been hit hard by the global financial crisis. The economy was particularly exposed to the crisis because of its large financial sector, high household indebtedness, and strong cross-border links. Economic activity has contracted sharply, the unemployment rate has increased, property prices have plunged, and inflation has fallen despite a significant depreciation of sterling.

\section{The authorities' policy response to the deep recession and financial crisis has} been forceful and wide ranging. Public capital has been injected into weak banks and their troubled assets are being ring-fenced. Banking sector liquidity has been shored up. Economic activity is being supported by an unprecedented easing of monetary policy and temporary discretionary fiscal stimulus. These aggressive policies have successfully contained the crisis, and there are tentative signs that confidence is returning. In addition, the floating exchange rate has acted as a shock absorber, with the depreciation of sterling offsetting to some extent the weakening of external demand.

3. Looking ahead, the economic recovery is expected to be subdued and gradual as banks and households go through a difficult balance sheet adjustment. With the economic downturn heightening the risk of further large credit losses, banks have tightened the supply of credit. The high level of household indebtedness is also likely to constrain the pace of economic recovery. GDP is projected to fall by about $4 \frac{1}{4}$ percent this year, with quarterly growth picking up gradually through 2010 . The speed and strength of the recovery, however, remain highly uncertain, given the unprecedented nature of the crisis and the importance of confidence effects.

4. Notwithstanding recent signs of stabilization, underlying vulnerabilities in the UK are sizeable. The financial crisis has brought about a dramatic deterioration in public finances. Public debt, although starting from a relatively low level, is projected to double in five years. The sharp increase in government borrowing and contingent liabilities, together with continued financial sector fragility, are significant vulnerabilities. In these circumstances, a severe shock has the potential to disrupt domestic and external stability. This highlights the importance of credible and consistent policies to truncate downside risks and strengthen market confidence. The main policy priorities remain, first, resolving the problems in the financial sector to buttress stability and promote normalization of credit supply, and second, setting monetary and fiscal policies consistent with a firm commitment to the existing policy anchors of price stability and fiscal sustainability.

\section{Repairing the financial system is essential for achieving a sustained recovery.}

The authorities' policy interventions have averted a systemic breakdown in the financial sector. But the financial system may not yet be repaired to level where banks are ready to increase lending sufficiently to underpin a strong recovery. Although major banks are expected to remain above minimum regulatory capital requirements, recession-related 
credit losses will lead to an erosion of capital buffers. At the same time, it is doubtful that increased capital market funding can compensate for shortfalls in bank lending. It will therefore be important for the authorities to continue to:

- Seek further strengthening of banks' capital positions by encouraging banks to take advantage of improving market conditions to augment their capital base and, if necessary, providing further public capital support.

- Promote options to preserve capital cushions and improve capital structures, for example by restraining dividend payouts not supported by profits and converting preference shares to common shares.

- Develop contingency plans in the event that further shocks threaten the stability of financial institutions.

- Support credit supply through targeted and appropriately designed intervention in dysfunctional credit markets.

6. Beyond the short term, the crisis has highlighted the need to strengthen the UK prudential framework. The adoption of a new Banking Act, which creates a special resolution regime for failing banks, together with the move to a more hands-on supervisory regime, are welcome improvements to the regulatory infrastructure. The shift to a more systematic approach to supervision should be complemented by enhanced disclosure of financial information by both banks and the FSA to reduce uncertainty and enhance public surveillance. The Turner Review represents an important contribution to the international debate on enhancing the regulatory and supervisory system. Progress on the following aspects, pursued in collaboration with international partners, will be particularly important to ensure future stability:

- Phased introduction of a maximum gross leverage ratio as a backstop against excessive balance sheet growth.

- Development of new macro-prudential instruments to mitigate the amplitude of the credit cycle and reduce feedback loops between the financial sector and the real economy.

- Overhaul of the EU's regulatory and supervisory arrangements, and in parallel strengthening cross-border arrangements for crisis management and orderly exit of large internationally active banks.

7. The Bank of England's strategy of aggressive monetary easing is appropriate.

On balance, the prospect is for inflation to fall and stay below the 2 percent target for an extended period. With policy rates near zero and conventional transmission channels partially impaired, the BoE has started purchasing assets financed by expanding central bank reserves. It is too early to judge the overall effectiveness of this quantitative easing policy, although the initial results are moderately encouraging-government bond rates 
have been kept low and liquidity in targeted private credit markets has improved. Diversifying further the Bank's private asset purchases could help improve the functioning of viable capital markets and sustain the flow of credit to the real economy.

8. The success of unconventional monetary policy rests on the robust institutional framework underpinning the Bank of England's operational independence. The prudent setup of the Asset Purchase Facility, which operates as a separate legal entity under comprehensive indemnity assurances from the Treasury, is therefore welcome. It protects the integrity of the BoE's balance sheet, a key prerequisite for monetary policy to remain focused strictly on price stability. It is also reassuring that the Monetary Policy Committee (MPC) will not need Treasury approval to determine and implement a future exit from quantitative easing as required to meet the inflation target. The exit could include a combination of asset sales, other liquidity-draining operations, and higher interest rates.

9. More fundamentally, the success of the current policy package hinges on continued trust in the sustainability of the fiscal position. A strong commitment to reverse the sharp deterioration of public finances within a reasonable timeframe is crucial. Therefore, once the economic recovery is established, implementing an ambitious fiscal consolidation plan will be essential. The focus should be on putting public debt on a firmly downward path faster than envisaged in the 2009 Budget. The credibility of such plans would be enhanced by clarifying early the specific measures needed to achieve the adjustment, including in the context of the next Comprehensive Spending Review. The emphasis in current plans to weigh the adjustment toward expenditure reduction is appropriate in light of international experience that expenditure-based consolidations are more durable. Long-term sustainability would also be helped by implementing structural reforms to address the rising costs associated with demographic change. Building a broad public consensus on the need for sizeable fiscal adjustment will be essential in meeting fiscal challenges.

\section{BALAnCe Sheet Strains}

10. Imbalances and balance sheet strains had emerged even before the recent global shocks triggered a sharp decline in economic activity (Figure 1 and Table 1). These included overheating in property markets, low domestic saving rates, high current account deficits, large external liabilities, rising (albeit still low) public debt, and significant increases in the leverage of financial sector and household balance sheets.

\section{A. Financial Institutions}

11. Banks are under pressure to deleverage. Banks' balance sheets expanded rapidly in the run up to the crisis. Assets relative to GDP nearly doubled over the last decade, with growth financed disproportionately through wholesale funding. At the same time, leverage steadily increased. Now, faced with deteriorating credit quality, large write-downs, and 
Figure 1. Real Sector

The UK economy has been weakening sharply...

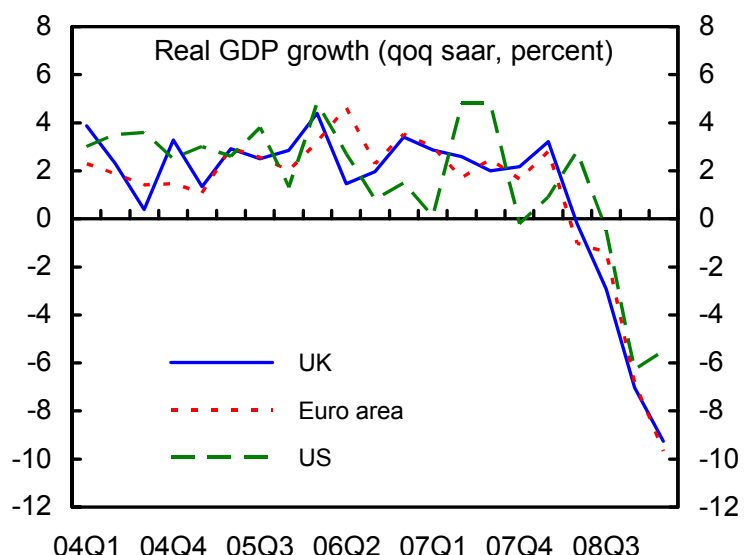

04Q1 04Q4 05Q3 06Q2 07Q1 07Q4 08Q3

Despite some recent pickup, the PMls continue to point to

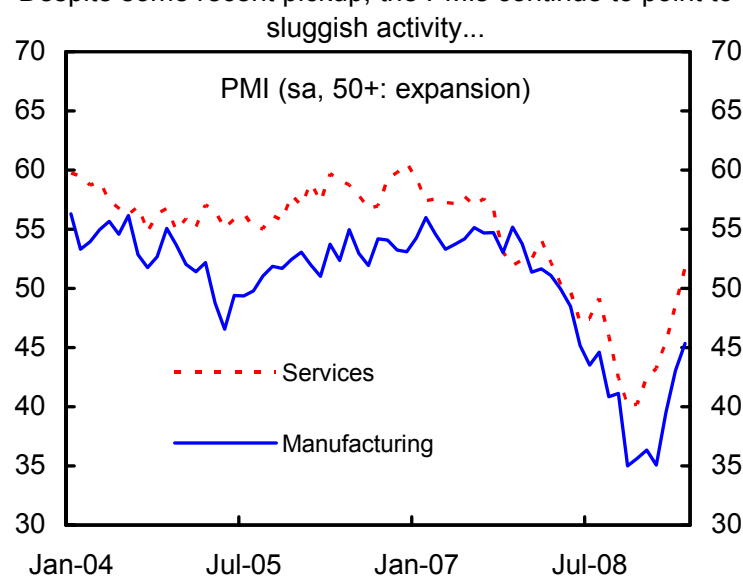

Firms have been rapidly shedding workers...

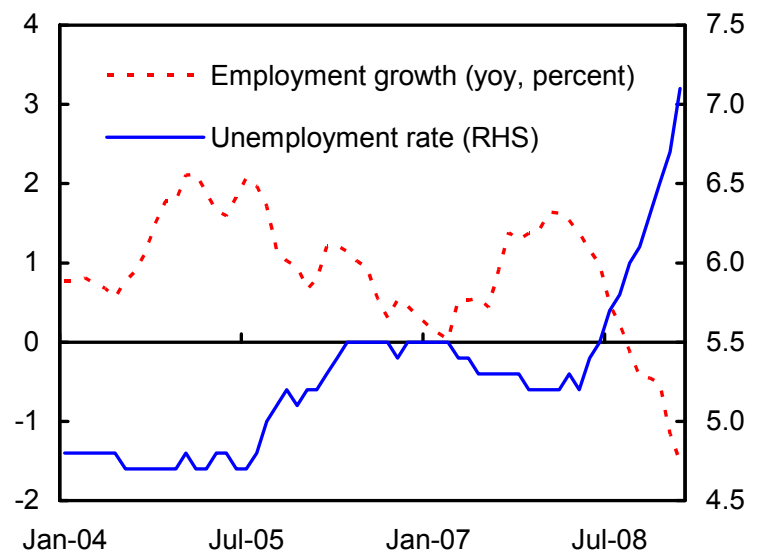

...mainly due to the rapid contraction in domestic demand

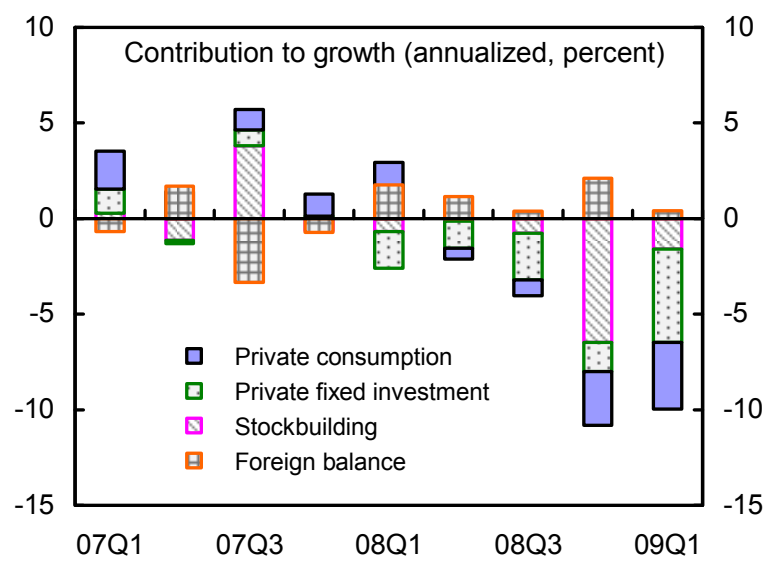

..amid weak confidence across economic sectors.

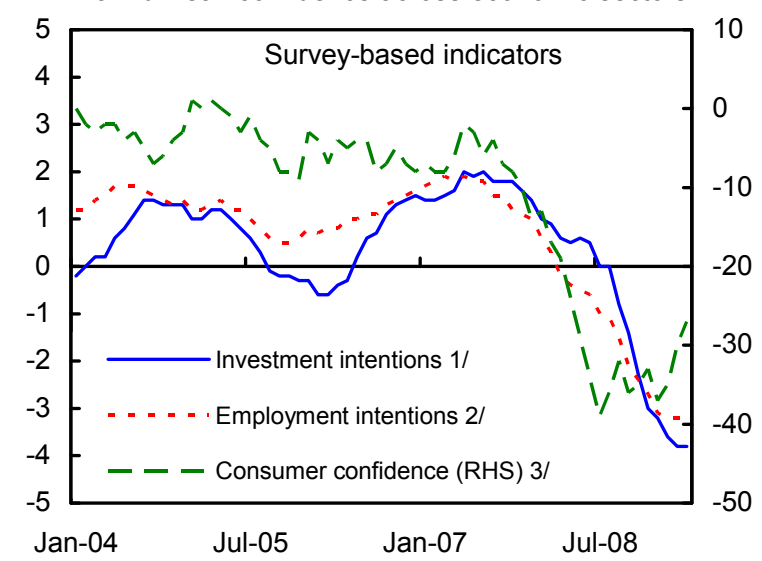

...reflecting expectations of continued weak activity

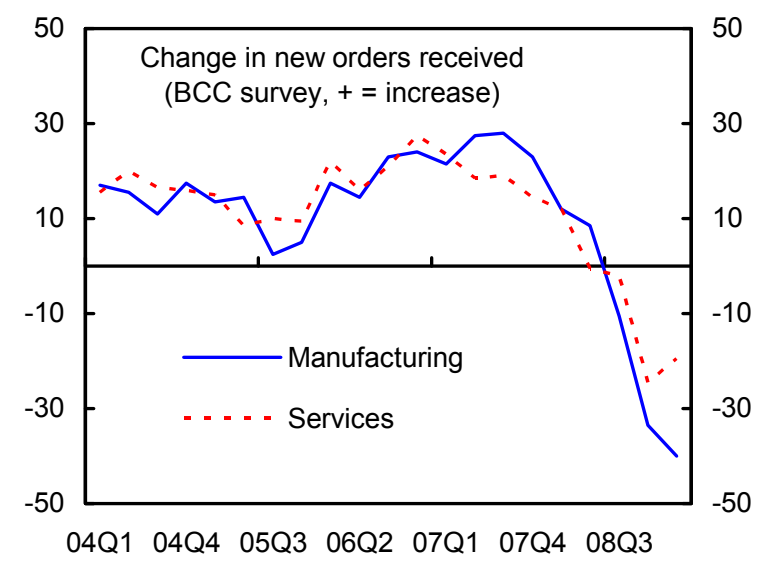

Sources: Bank of England, British Chambers of Commerce, Office of National Statistics, Markit Economics.

1/ Bank of England Agents' Survey, manufacturing.

2/ Bank of England Agents' Survey, services.

3/ GfK Consumer Confidence Barometer. 
difficult funding conditions, banks have little choice but to reduce leverage. Deleveraging is taking place through capital-raising efforts, asset sales, reduced lending growth, and some retrenchment of cross-border operations.

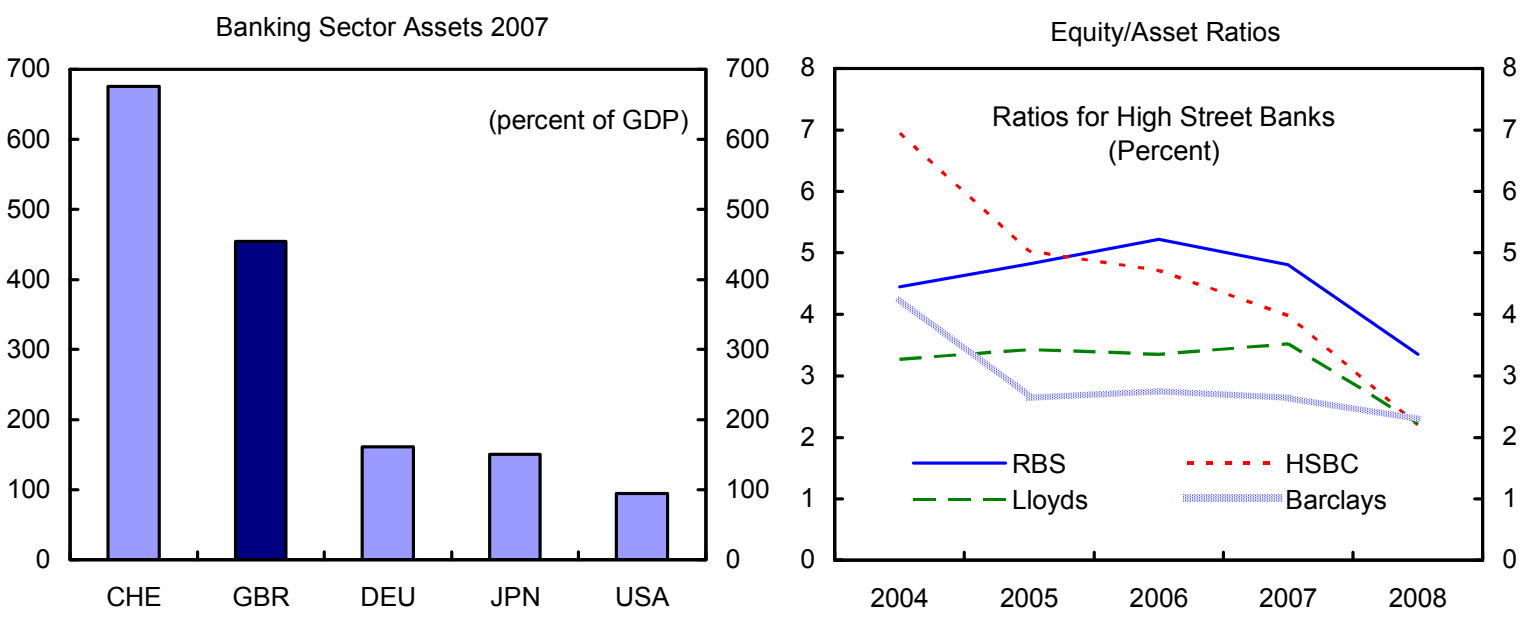

Sources: International Financial Statistics; Bankscope; and staff calculations.

12. Financial strains have started to ease, although the situation remains far from normal. Aggressive policy actions have largely dispelled concerns about liquidity, helping to ease conditions in interbank term lending markets (see Annex I for a full list of the policy measures). Some large institutions have also been able to issue unsecured debt and fresh equity recently, suggesting improving market confidence. Nonetheless, major banks' equity prices remain significantly below pre-crisis levels, despite a recent rebound, and debt issuance is still largely dependent on government debt guarantee schemes. Risk premia also indicate continued stress - spreads on bank debt, credit default swaps, term lending, and currency swaps all remain above historical averages (Figure 2). Meanwhile, asset-backed security markets are essentially closed.

\section{The persistence of difficult funding conditions is a symptom of lingering} concerns about the extent of potential credit losses. UK banks reported record writedowns and losses for 2008 (especially on their foreign exposures), although strong revenue allowed some banks to return to net profit in the first quarter of 2009. Substantial further write-downs are expected in 2009 and 2010. The government has stepped in to support banks in distress, providing large capital injections to RBS and Lloyds. The two banks also placed $£ 585$ billion of assets under the government's Asset Protection Scheme, which provides insurance against large downside risks on these assets. Nonetheless, with the weak state of the economy, uncertainty about the extent of potential future losses in the banking system remains high. In this environment, the building society sector is facing particular vulnerabilities arising from a concentration in real estate lending, a strained funding model, and limited access to new capital. 
Figure 2. Banking Indicators

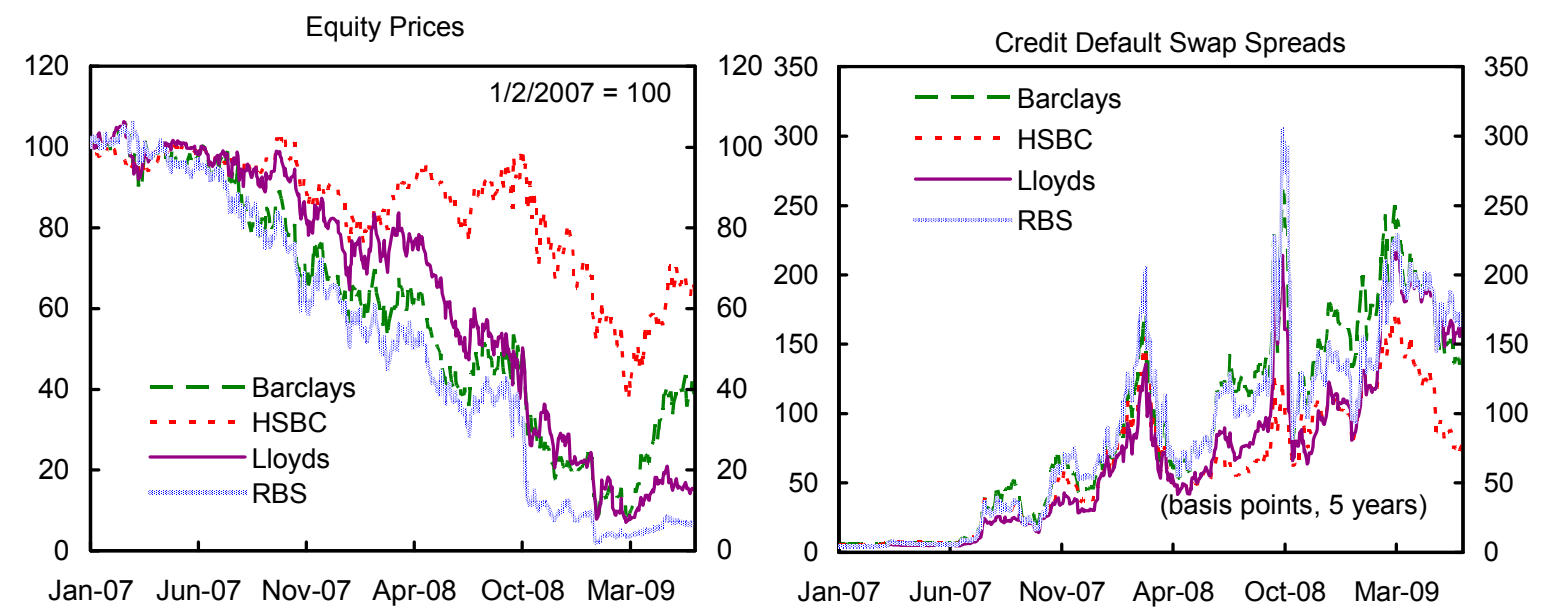

Spreads of Three-Month Unsecured Interbank Rates
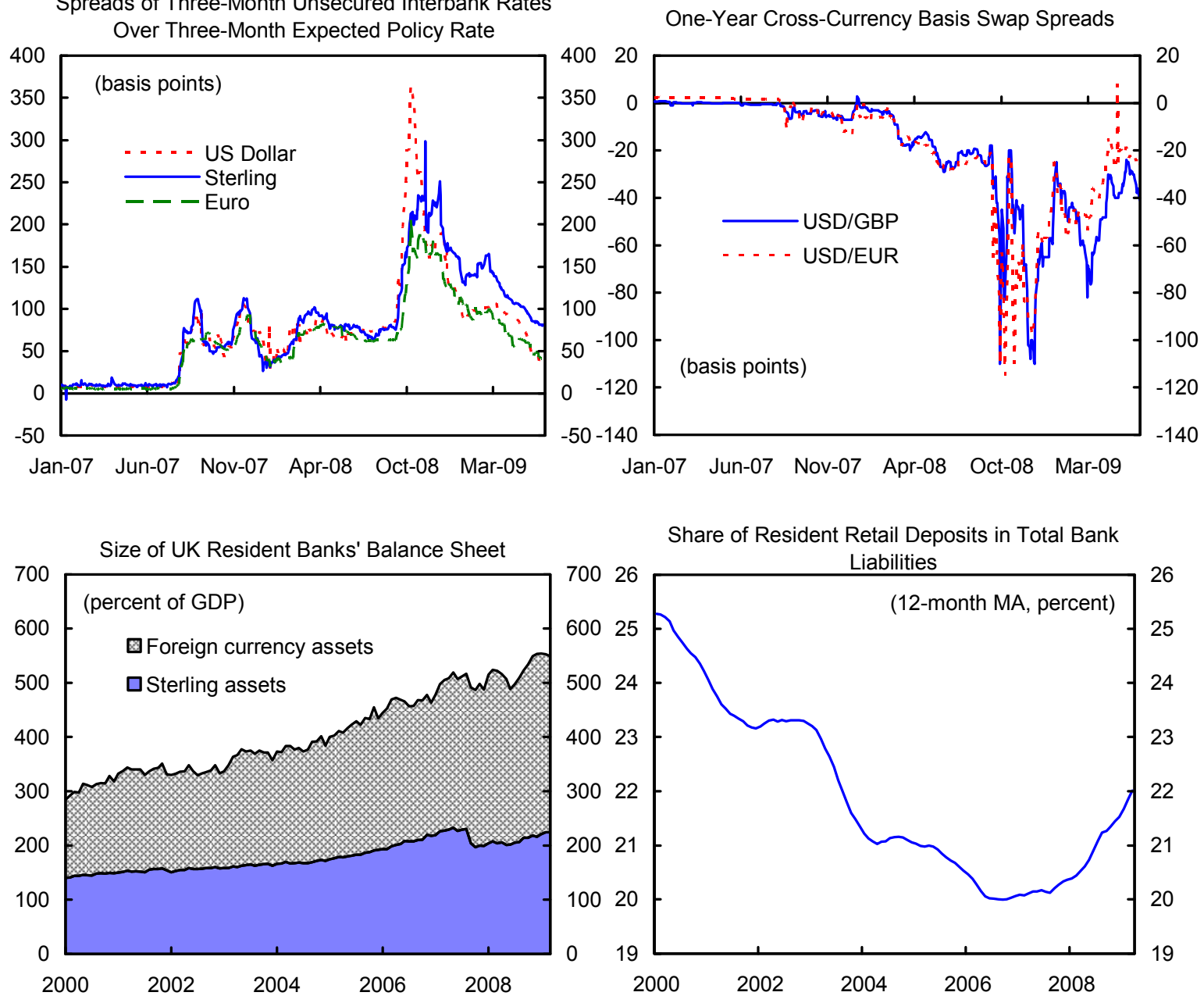

Sources: Bank of England, Bloomberg. 


\section{B. Households and Corporations}

14. Household balance sheets are also highly leveraged. In the run-up to the crisis household debt increased to 175 percent of disposable income - one of the highest levels among advanced countries (Figure 3). The rise in debt was matched by an increase in the value of housing, pension funds, and other financial assets held by households. However, the sharp fall of asset prices since the beginning of the crisis has eroded the value of household portfolios. Net household wealth in the UK is estimated to have declined by about 15 percent in 2008, and may fall further in 2009 .

\section{House prices have dropped by more than $\mathbf{2 0}$ percent from their peak and} commercial real estate prices are down by 40 percent. So far, prices have been falling much faster than in the previous major real estate price correction during the early 1990s (Figure 4). Mortgage arrears and bank repossessions of properties have increased, although they are still relatively low as a share of existing mortgages. The foreclosure rate in 2008 was only 0.35 percent, compared to $4 \frac{1}{4}$ percent in the United States. Delinquency rates on non-conforming mortgage-backed securities of the newer vintages are going up, but are still not far above the rates on older vintages (and are much lower than the delinquency rates on US subprime mortgages). Despite some recent positive news, forward-looking indicators such as mortgage approvals and the sales-to-stock ratio suggest that the housing price adjustment is yet to be completed.

\section{Consumer spending has weakened on falling wealth, rising unemployment,} and tighter credit constraints. Employment is declining, and the unemployment rate reached 7.2 percent in the three months to April 2009. The rise in uncertainty about future income and employment prospects and the fall in household wealth are weighing on consumer confidence. Simultaneously, credit constraints have become more binding: recent credit conditions surveys show significant tightening of credit standards for both secured and unsecured household lending. As a result, the household saving rate has been rising - from very low levelssince early 2008.

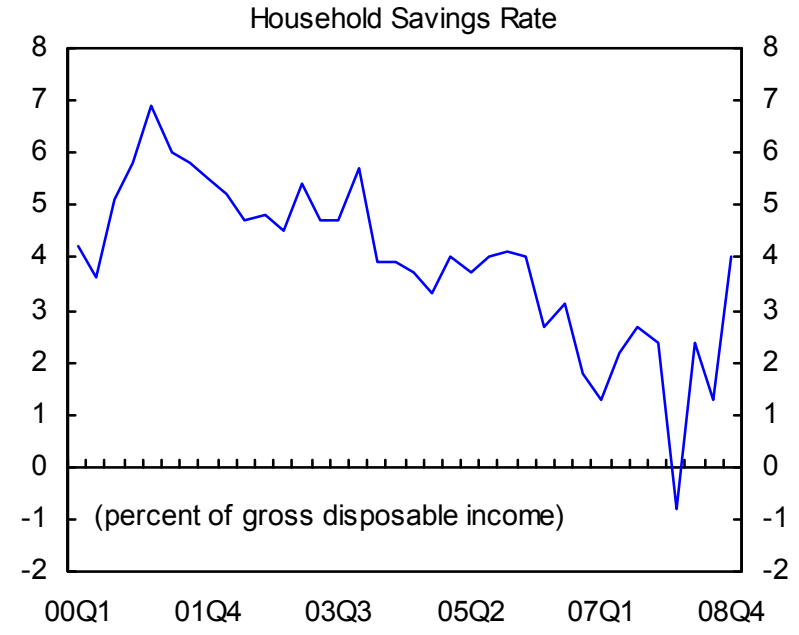

Sources: Office of National Statistics and staff calculations. 
Figure 3. Households and Corporates
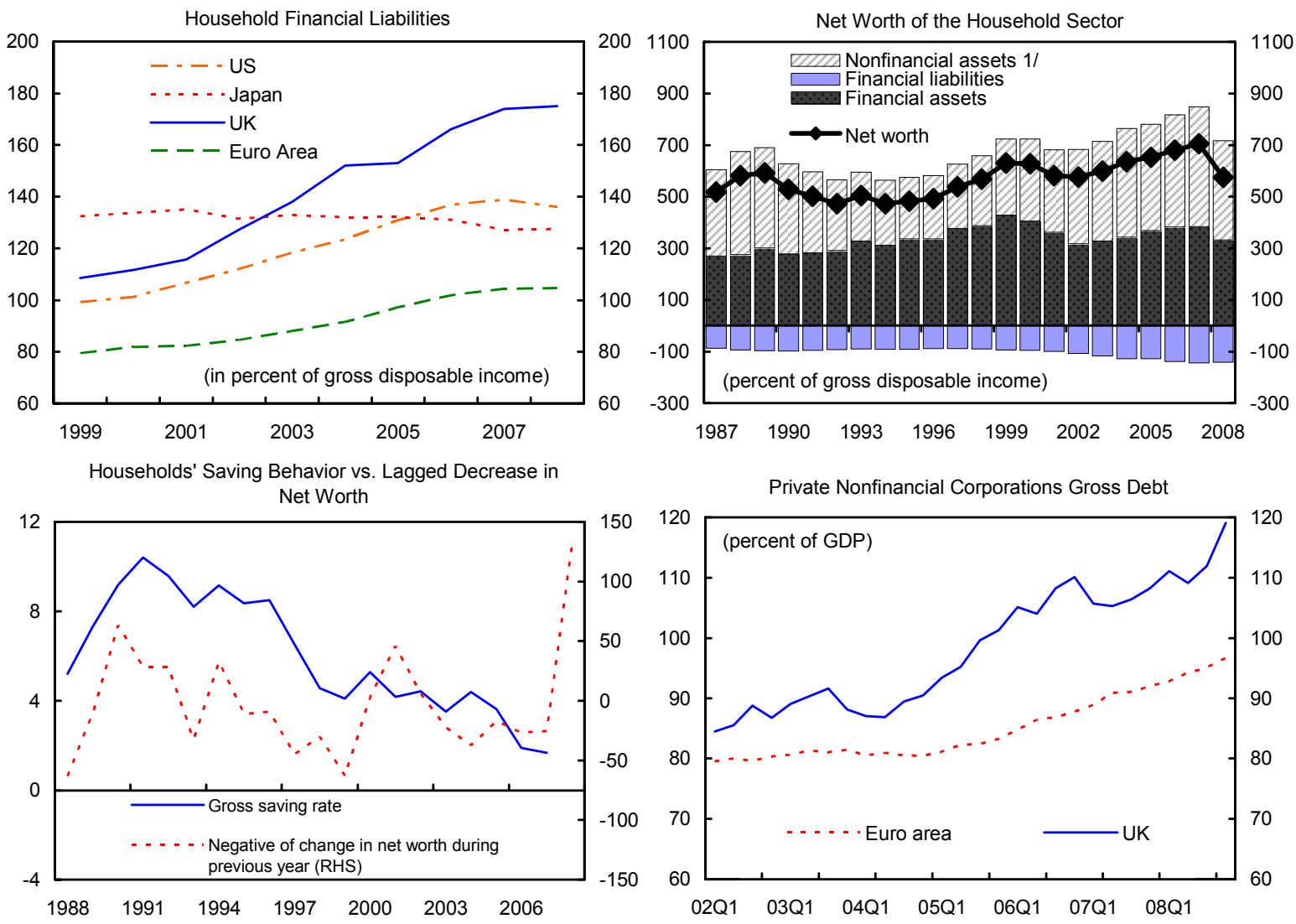

Private Nonfinancial Corporations Liquid Assets 2

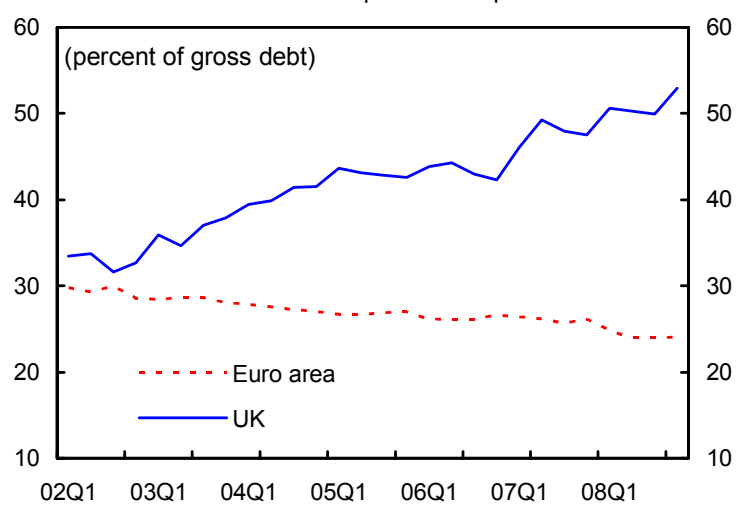

Liquidations and Write-offs

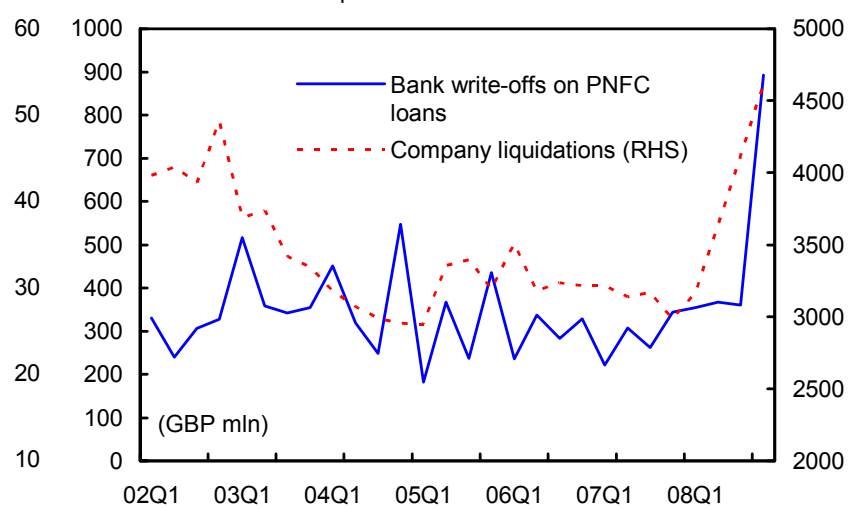

Source: Haver Analytics.

1/ For 2008: staff estimate.

2/ Liquid assets: sum of currency, deposits, and debt security holdings. 
Figure 4. Property Prices
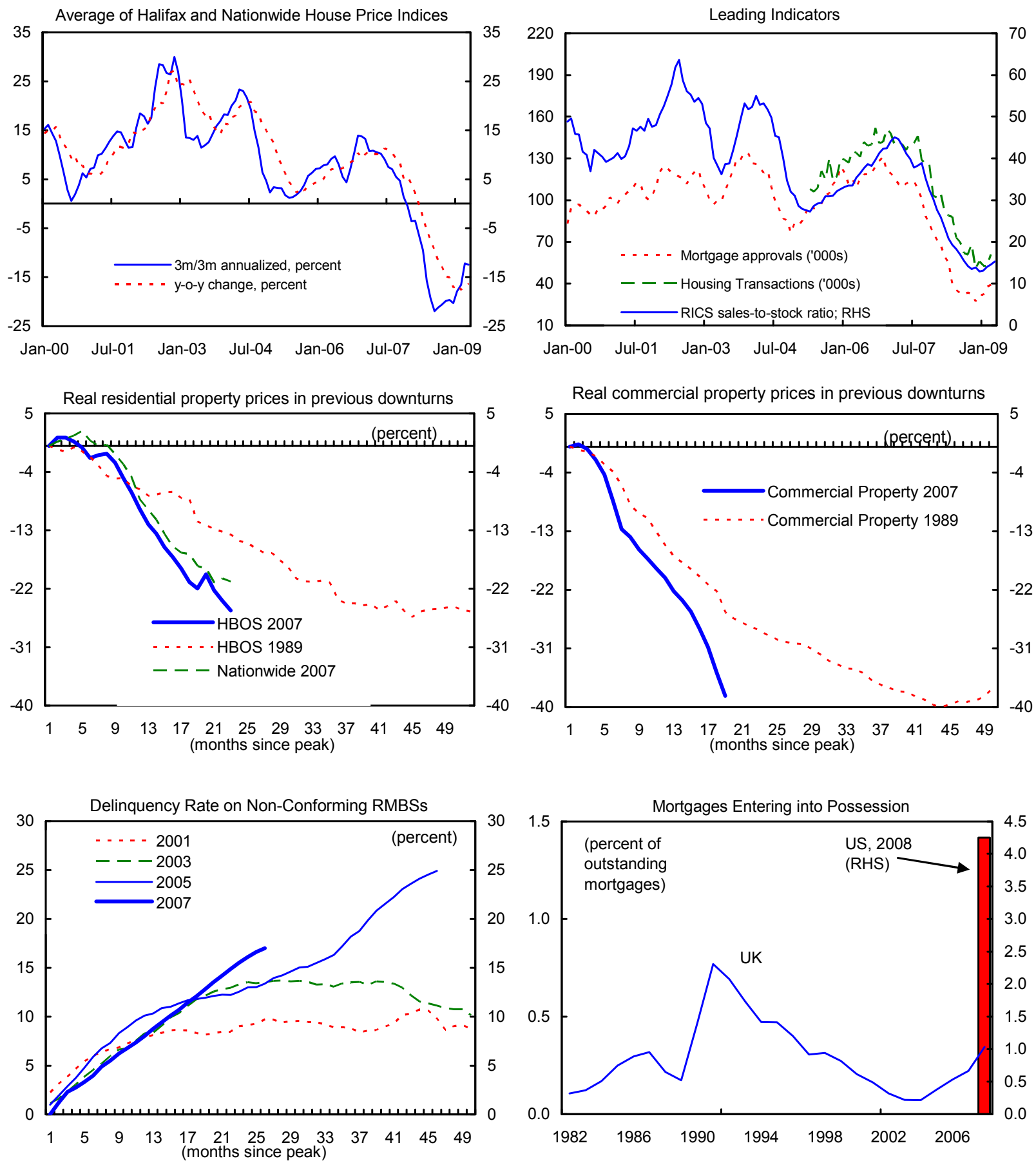

Sources: Bank of England, UK Council of Mortgage Lenders, US Mortgage Bankers Association, Haver Analytics, Fitch, and staff estimates. 


\section{Firms entered the crisis with relatively strong balance sheets, but}

vulnerabilities are increasing. The rise in non-financial corporate debt over the last decade has been moderate, and firms have held substantial liquid financial assets (Figure 3). However, the profit outlook has deteriorated as demand continues to contract and credit conditions remain tight. Business investment has declined steadily over the last year, and surveys suggest that both demand for and supply of credit to corporations have contracted. Default rates have started to rise, although from a low base. The steep fall in commercial property prices has reduced further the net worth of corporations.

\section{Macro-Financial Linkages}

18. Over the past year, adverse feedback loops developed between deteriorating financial conditions and a weakening economy. Banks, constrained by tight capital positions and a difficult funding environment, reduced lending to the private sector. As house prices kept falling, the value of pensions and other financial assets declined, and job security became elusive, consumers retrenched their spending. The decline in consumption, in turn, reduced business profits and depressed investment, leading to further falls in employment and income. Demand for credit also weakened as households and businesses tried to repair their balance sheets. The actual and prospective rise in defaults and bankruptcies has weakened further the balance sheets of banks and their ability and willingness to restart lending.

\section{As a result, credit flows have stagnated and lending rate spreads remain high.}

The monthly growth of both secured and unsecured household credit has fallen almost to zero. A pick up in the issuance of bonds by the corporate sector in recent months has not been sufficient to offset the net decline in business credit from banks. Indeed, the reduction in credit growth is steeper than in previous recessions. At the same time, lending spreads remain wide, reflecting a perception of high credit risks and increased capital costs. Corporate bond spreads over government bonds also remain elevated (Figures 5 and 6).

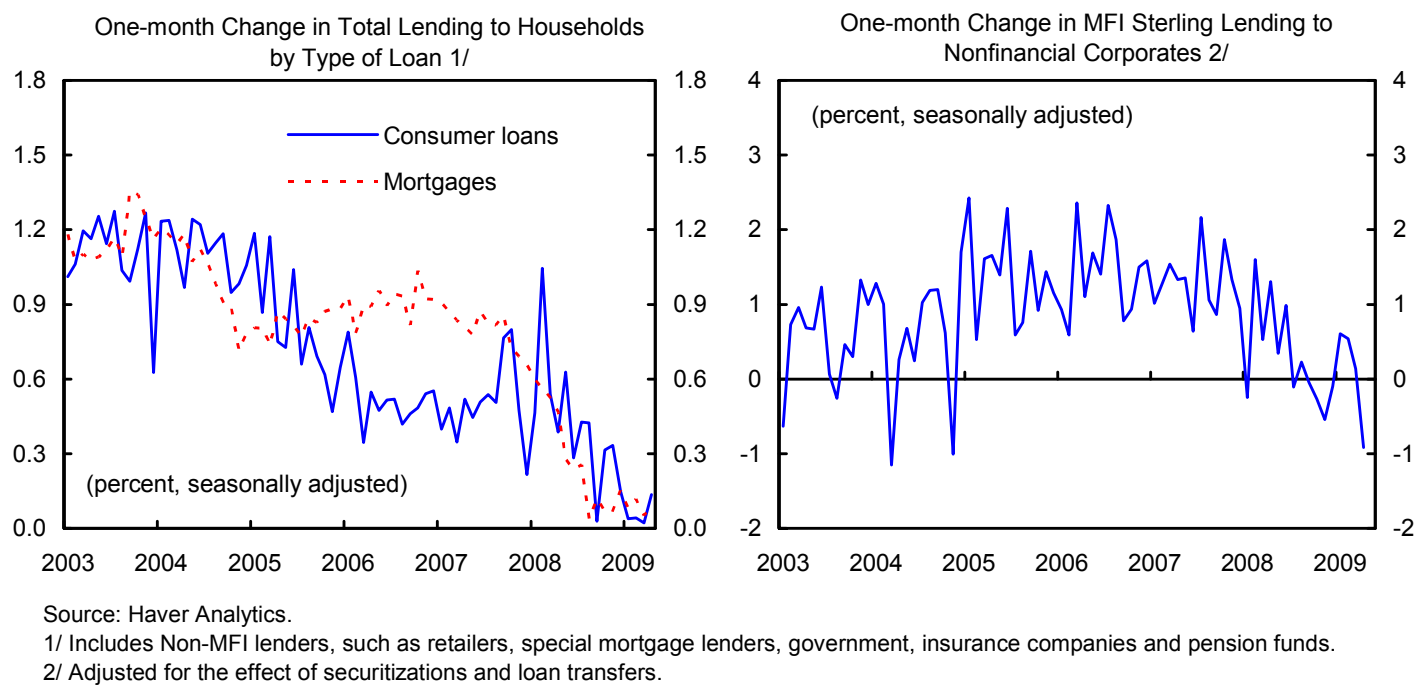


Figure 5. Credit and Capital Market Developments
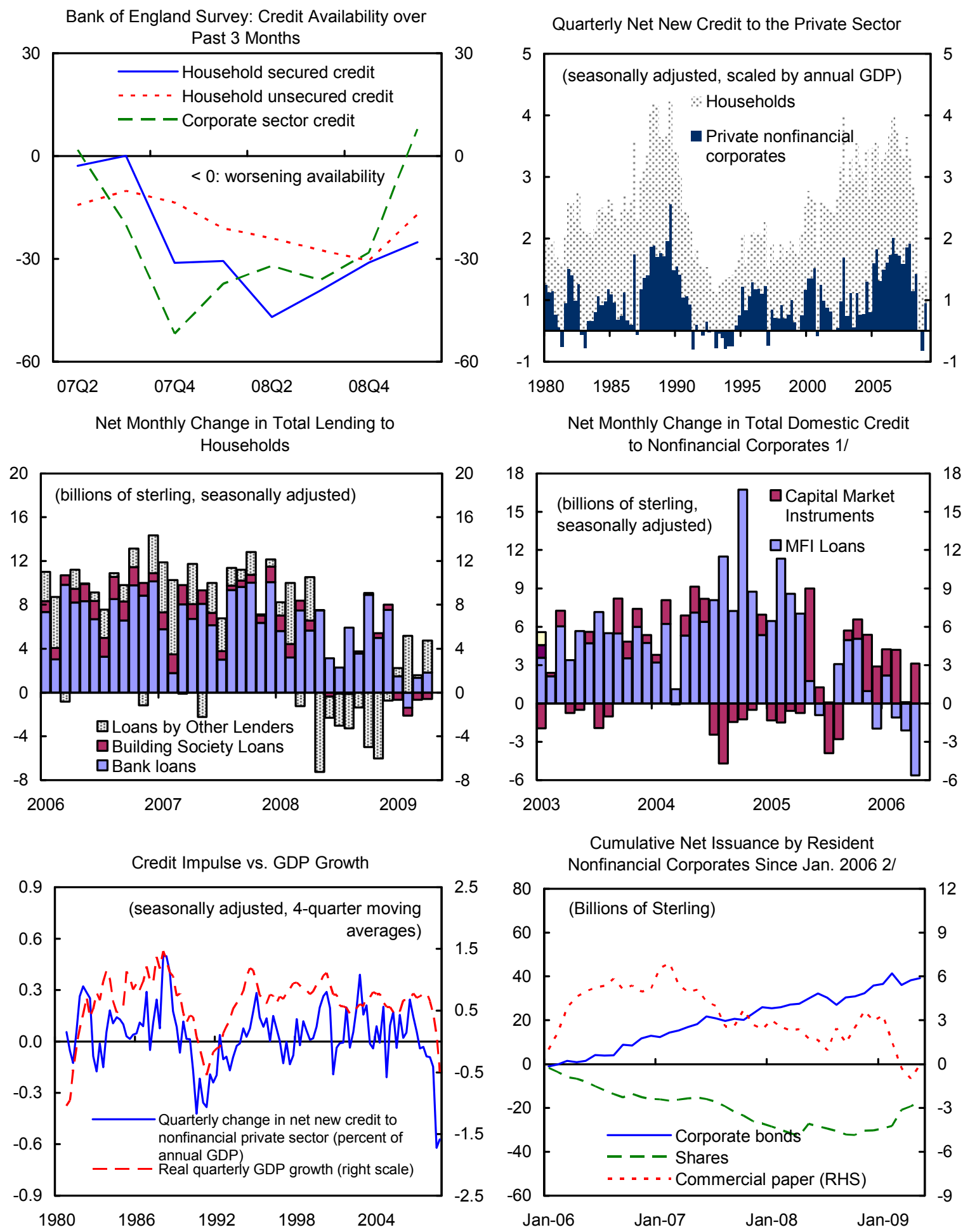

Sources: Bank of England; UK Statistics Authority; and IMF staff calculations. $1 /$ Includes domestic loans and capital issuance in foreign currency. 2/ All currencies. 


\section{Figure 6. Lending Spreads}

Spreads on fixed-rate mortgages with moderate loan-to-value ratios have risen since the beginning of the crisis in mid-2007; high-LTV mortgages initially turned more expensive, but have become largely unavailable of late.

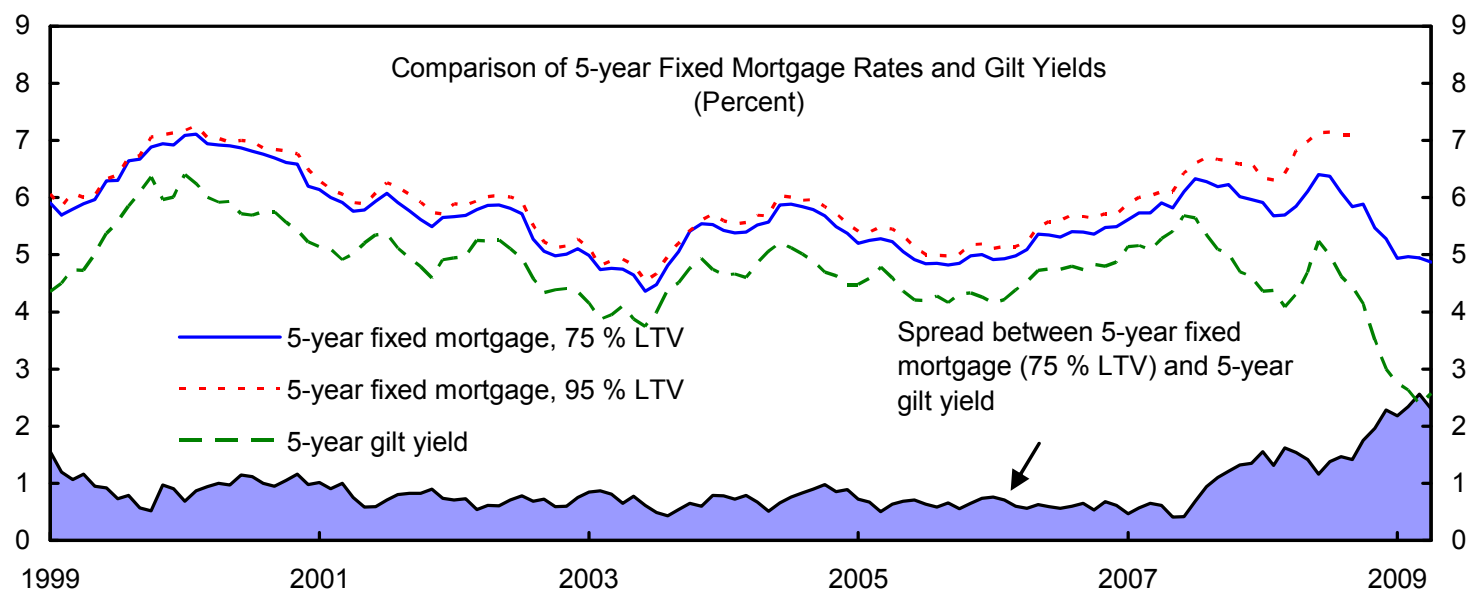

The rise in spreads on variable-rate mortgages is a more recent phenomenon, as lending rates have not mimicked the full decline in policy rates since late 2008.

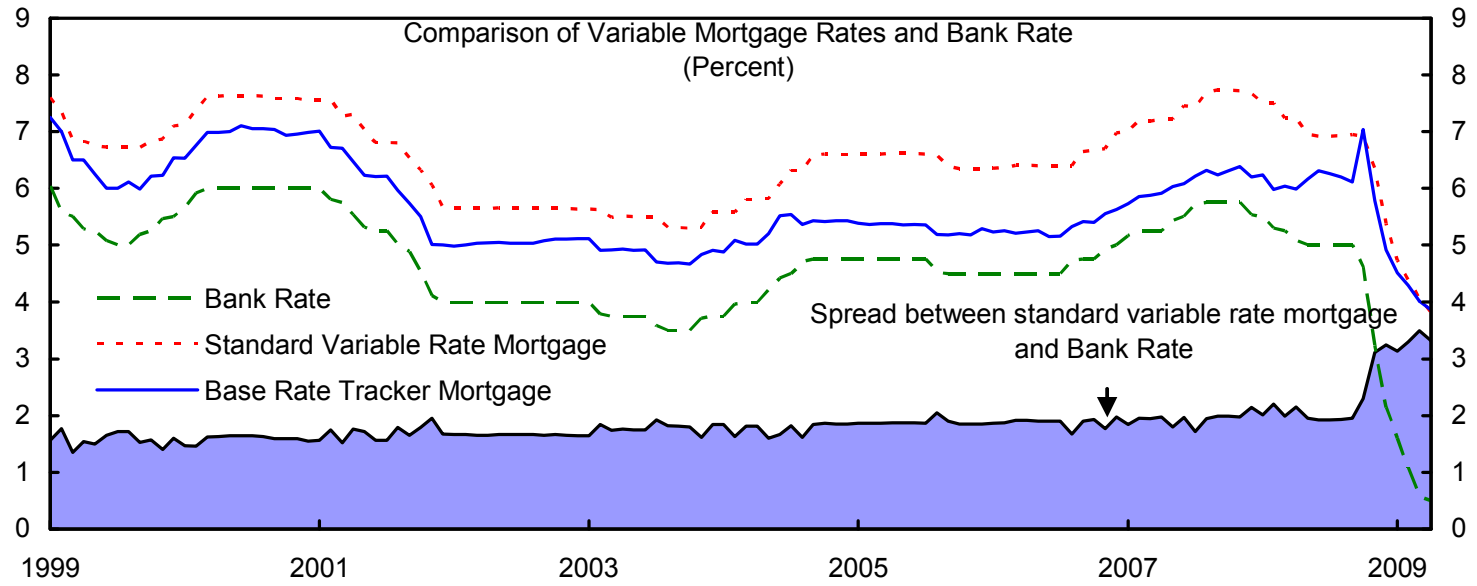

Credit Spreads of Corporate Bonds with Maturities 7-10 Years Over Gilts

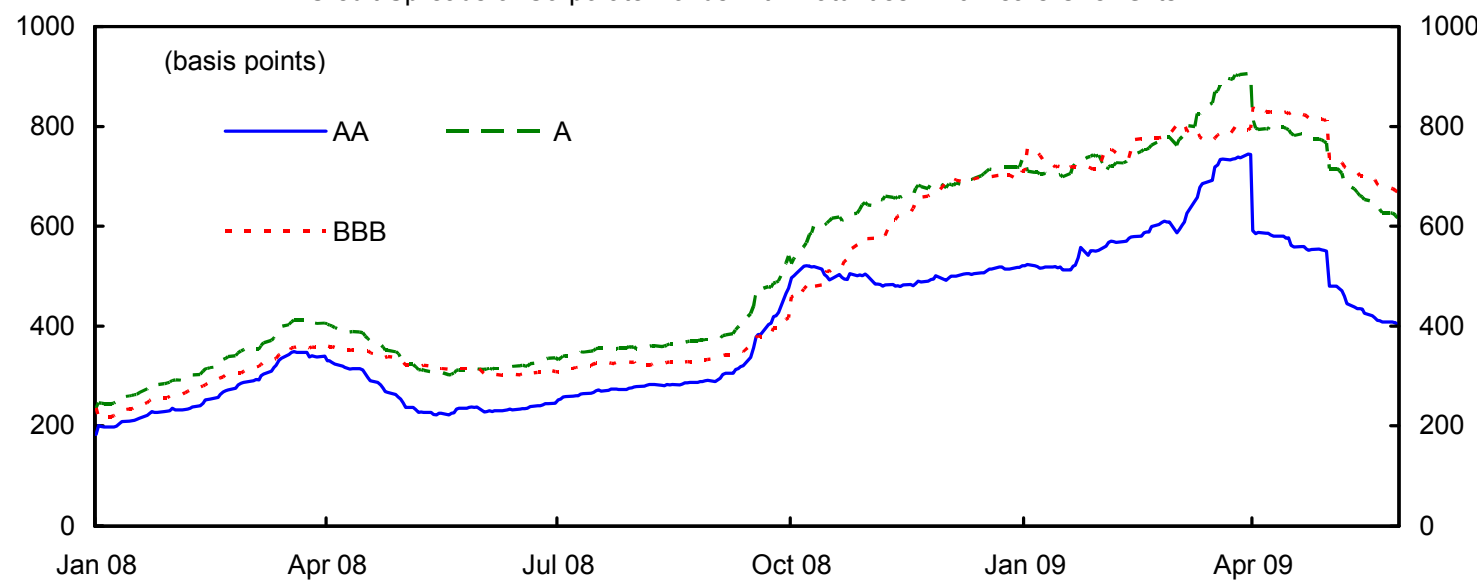

Sources: Bank of England; Datastream. 


\section{The Public Sector Balance Sheet}

\section{The financial crisis and the recession have led to a sharp deterioration of}

public finances. Revenue in the UK is sensitive not only to the economic cycle, but also to asset prices and the level of financial sector activity. The synchronized downturn of the economic and asset price cycles led to a rapid decline in income and corporation taxes, VAT, and asset price-related revenues. The headline deficit in 2008/09 was $6 \frac{1}{2}$ percent of GDP and deficits of about 13 percent of GDP are projected for 2009 and 2010 (Table 2).

Discretionary fiscal stimulus of 2 percent of GDP is being implemented. The main components of the stimulus package are a temporary reduction of the VAT rate, larger personal income tax allowances and pension transfers, and advancing of planned capital expenditure. Nonetheless, the size of the discretionary stimulus and its impact on debt levels is small compared with the effect of automatic stabilizers and the loss of asset pricerelated revenue (Figure 7).
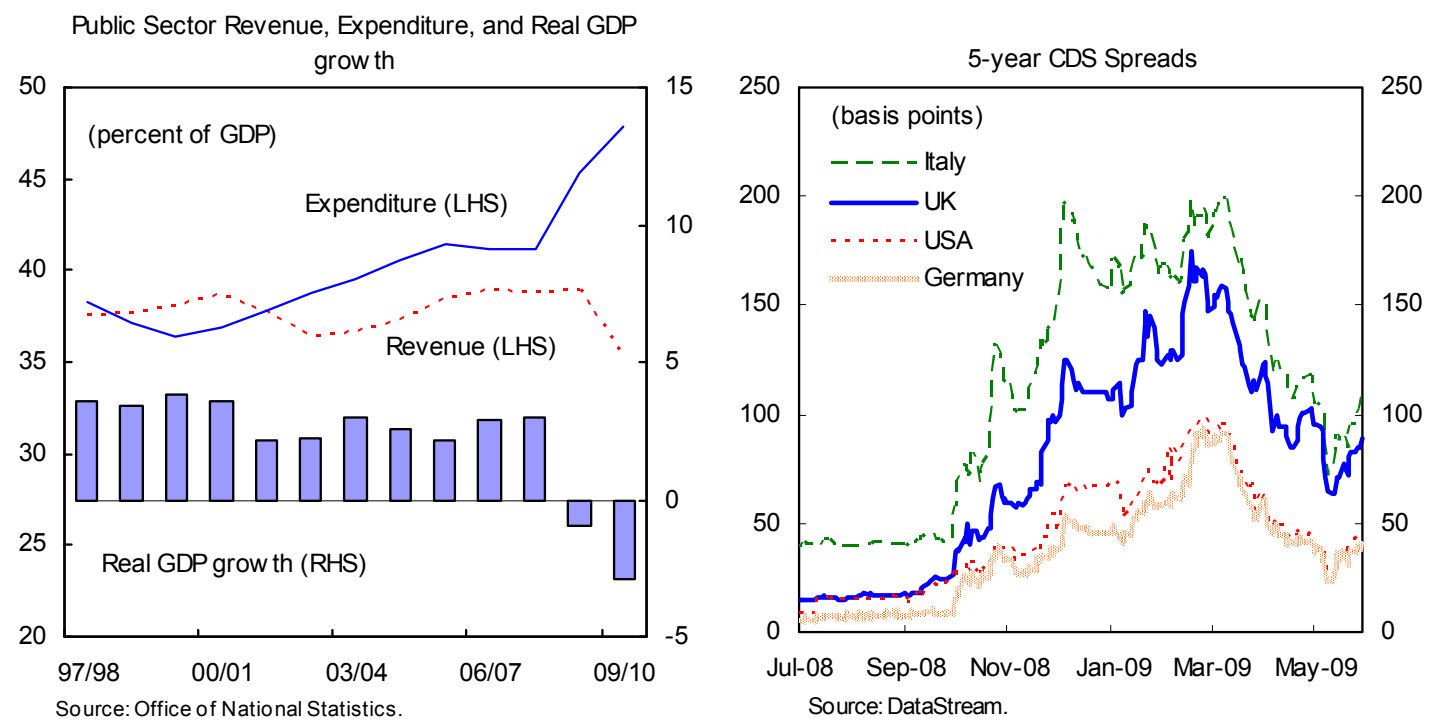
Figure 7. Fiscal Developments
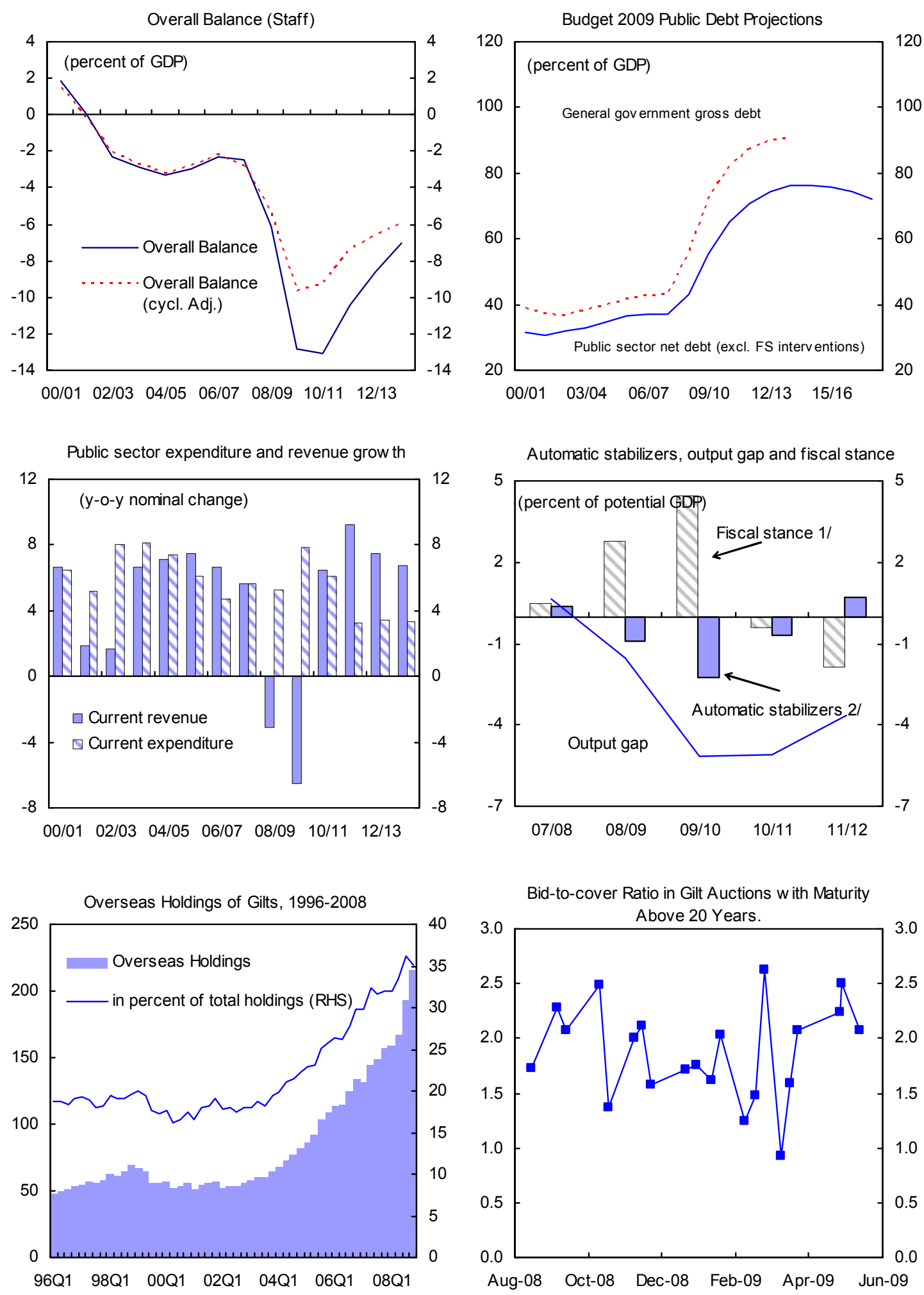

Sources: HMT, DMO and IMF staff estimates.

$1 /$ Negative of the change in cyclically adjusted balance. $2 /$ Change in cyclical balance. 
21. Public debt is rising fast. The structural fiscal position was already weak at the onset of the crisis - government expenditure as a share of GDP has increased substantially in the last decade, while some of the revenue strength financing the increase has proved to be unsustainable (see chart above). Sizable fiscal deficits were recorded even as the cycle reached its peak. The post-crisis increase in net borrowing is projected to result in a doubling of gross general government debt over the next 5 years to about 99 percent of GDP. ${ }^{1}$ At the same time, contingent liabilities of the government from financial sector interventions have increased sharply. Gross resources committed to financial sector support measures so far have exceeded 60 percent of GDP, although the net cost to taxpayers is likely to be much smaller (see table). ${ }^{2}$

Selected Financial Sector Support Measures

\begin{tabular}{|c|c|c|}
\hline & \multicolumn{2}{|c|}{ Public sector exposure } \\
\hline & $£$ billion & percent of GDP \\
\hline Financial sector support & 126.6 & 8.8 \\
\hline Northern Rock $1 /$ & 14.6 & 1.0 \\
\hline Bradford \& Bingley 1/ & 24.0 & 1.7 \\
\hline Kaupthing Singer \& Friedlaender & 3.3 & 0.2 \\
\hline Landsbanki & 4.5 & 0.3 \\
\hline Heritable & 0.5 & 0.0 \\
\hline Dunfermline & 1.6 & 0.1 \\
\hline Bank recapitalization & 78.1 & 5.5 \\
\hline Increase in contingent liabilities & 777.3 & 54.3 \\
\hline Credit Guarantee Scheme & 250.0 & 17.5 \\
\hline Working Capital Scheme & 11.5 & 0.8 \\
\hline Asset-Backed Securities Guarantee Scheme & 50.0 & 3.5 \\
\hline Asset Protection Scheme 2/ & 465.8 & 32.5 \\
\hline Total exposure & 903.9 & 63.1 \\
\hline \multicolumn{3}{|l|}{ Memo items } \\
\hline Special Liquidity Scheme (SLS) & 185.0 & 12.9 \\
\hline Asset Purchase Facility (APF) & 150.0 & 10.5 \\
\hline
\end{tabular}

${ }^{1}$ Based on staff's projections (Table 6). General government gross debt refers to the consolidated gross liabilities of the central and local governments. It includes the gross cash cost of financial sector interventions (which are excluded from the public sector net debt unless specifically noted). Public sector net debt measures the liabilities net of liquid assets of the general government, public corporations, and the Bank of England. A broader measure of public sector net debt will also include the liabilities of the nationalized banks, net of liquid assets.

${ }^{2}$ The 2009 Budget assumed that the net cost of financial interventions will be 3.5 percent of GDP. 


\section{E. Sterling and the UK External Position}

\section{The depreciation of sterling has helped improve the UK's external position.}

Reflecting an increased risk premium, sterling depreciated by 27 percent between mid2007 and April 2009 in real effective terms (Annex II). The trade deficit has narrowed, reducing the current account deficit (Figure 8 and Table 3). Moreover, with most of UK's large external assets (and a smaller fraction of external liabilities) denominated in foreign currencies, the income balance improved and UK's net international investment position strengthened significantly due to valuation effects (Table 4). Since April, some of the depreciation has been reversed (text chart). Based on estimates using CGER-type methodologies, sterling is broadly in line with

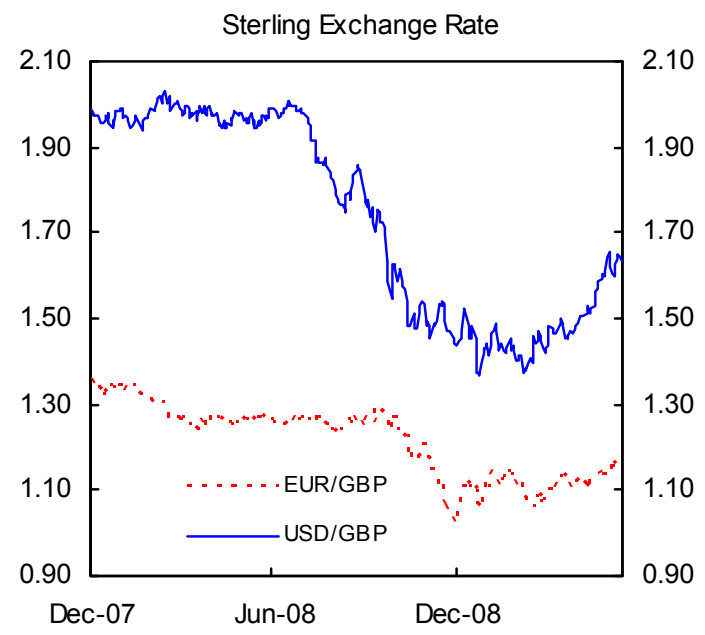
fundamentals as of June 2009.

\section{Cross-Border SPILlovers}

\section{The UK is closely integrated with the world economy, through both trade and} financial links. On the trade side, the currency depreciation and the limited dependence on durable goods exports have helped mitigate the decline in export demand. Nonetheless, with the global economy in a deep recession and income effects dominating the price effects, export volumes dropped by 20 percent annualized in the last quarter of 2008 and the first quarter of 2009. The decline in imports was equally dramatic, affecting in particular trading partners in the euro area.
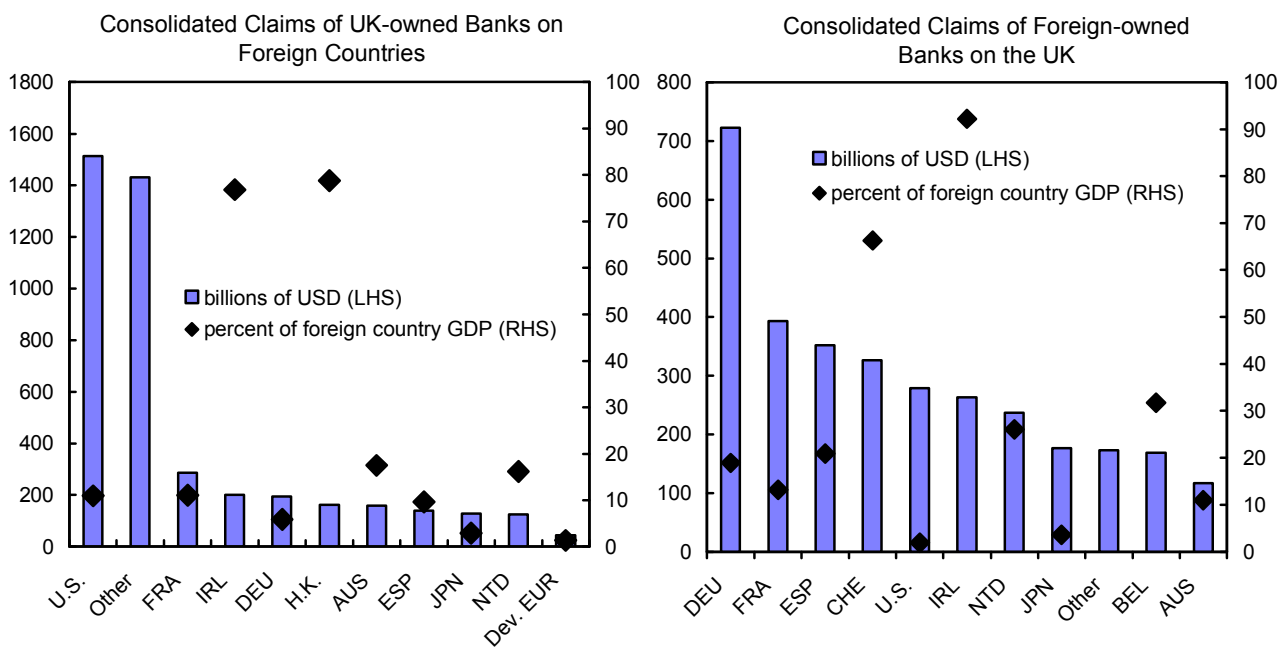

Sources: Bank of England; Bank of International Settlements. Data as of end September 2008. 
Figure 8. External Sector
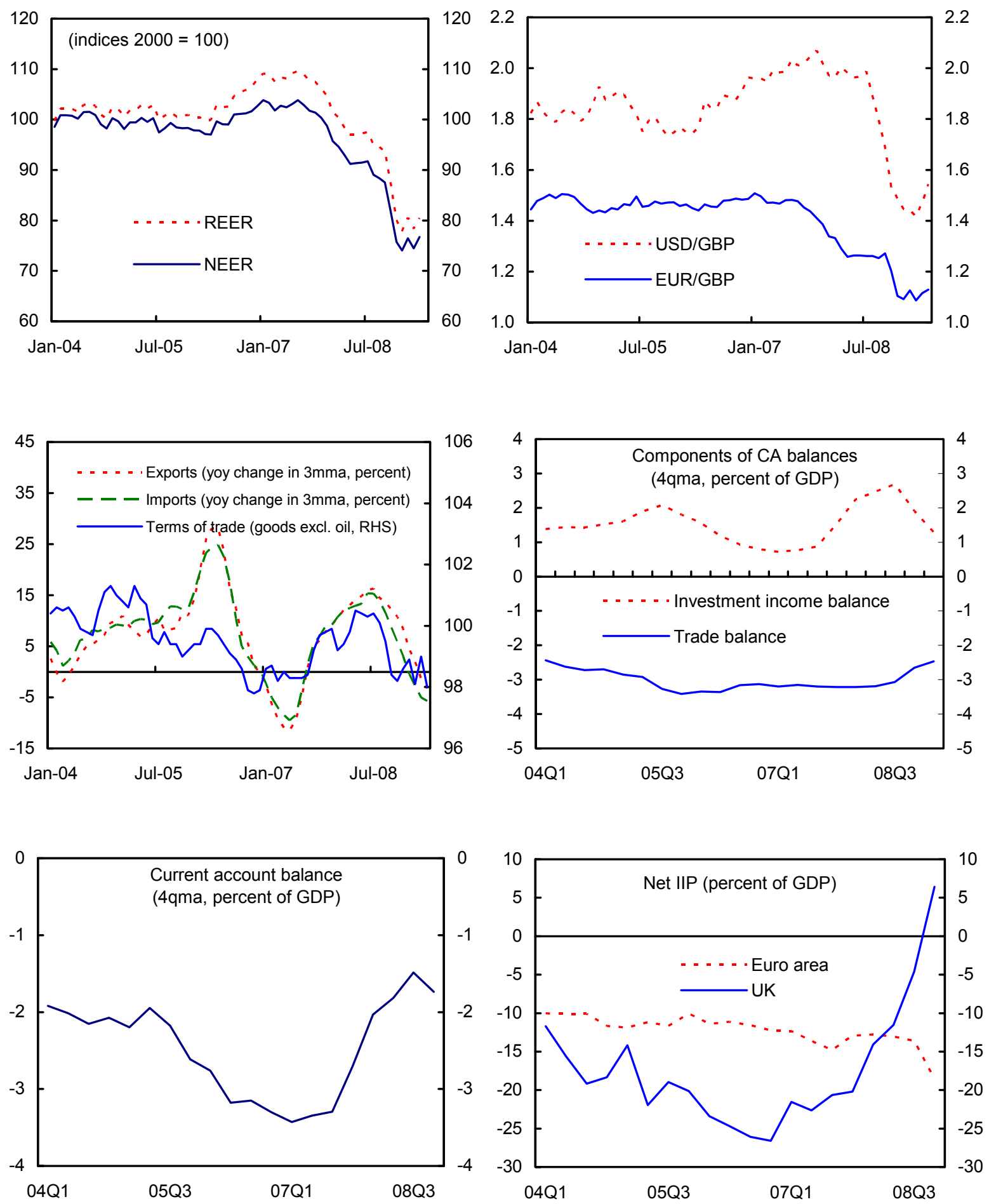

Sources: Haver Analytics, International Financial Statistics. 


\section{Shocks to the global financial system are quickly transmitted to the domestic}

financial system. The five largest UK-owned banks are very active internationally-their external assets exceed 200 percent of UK GDP. UK banks have substantial operations in the United States, Western Europe, and some Asian economies, including strong linkages with foreign financial institutions (text chart above). Developments in these economies will continue to influence the health of the UK's financial system. Indeed, statistical analysis shows that the stock prices of several large UK banks are heavily affected by changes in US banks' equity values (more so than other large European banks, text chart below).

Conversely, shocks to the UK banking system could have spillovers across the globe (see Box 1).

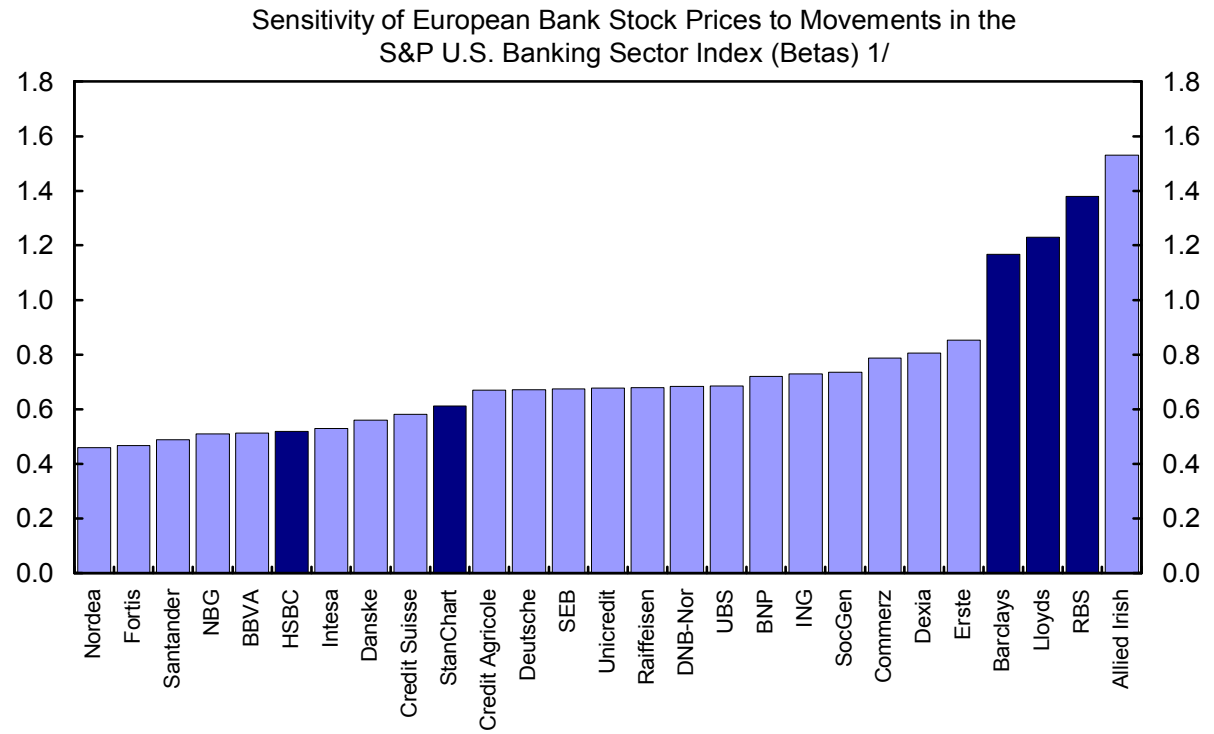

1/ Beta from a regression of individual bank stock return on index return and constant; estimated for weekly US\$-based log returns for the period July 25, 2007 to May 27, 2009. 
Box 1. Potential Spillovers from the UK Financial System to the Rest of the World

UK-owned banks maintain very significant global operations. Their consolidated foreign claims stood at almost US\$3.7 trillion at end-2008. Although interbank loans account for about one quarter of these claims, UK banks also maintain a significant retail business with firms and households abroad, through both subsidiaries and branches (mimicking the significant presence of foreign-owned banks in the UK banking market).

A sharp deleveraging drive, therefore, presents a particular spillover threat. The final quarter of 2008 saw a rapid trimming of overseas exposures (minus 16 $\frac{1}{2}$ percent quarter-onquarter), most notably in the interbank market. Sharp further deleveraging of UK-owned banks - perhaps triggered by new adverse shocks — would imply a significant withdrawal of credit from many countries of operation. To illustrate the relative vulnerabilities, a hypothetical across-the-board cut in UK banks' foreign lending by 50 percent, a very harsh shock by any historical standard, was examined.

Figure: Withdrawal of Countries' External Credit as a Result of UK Bank Deleveraging

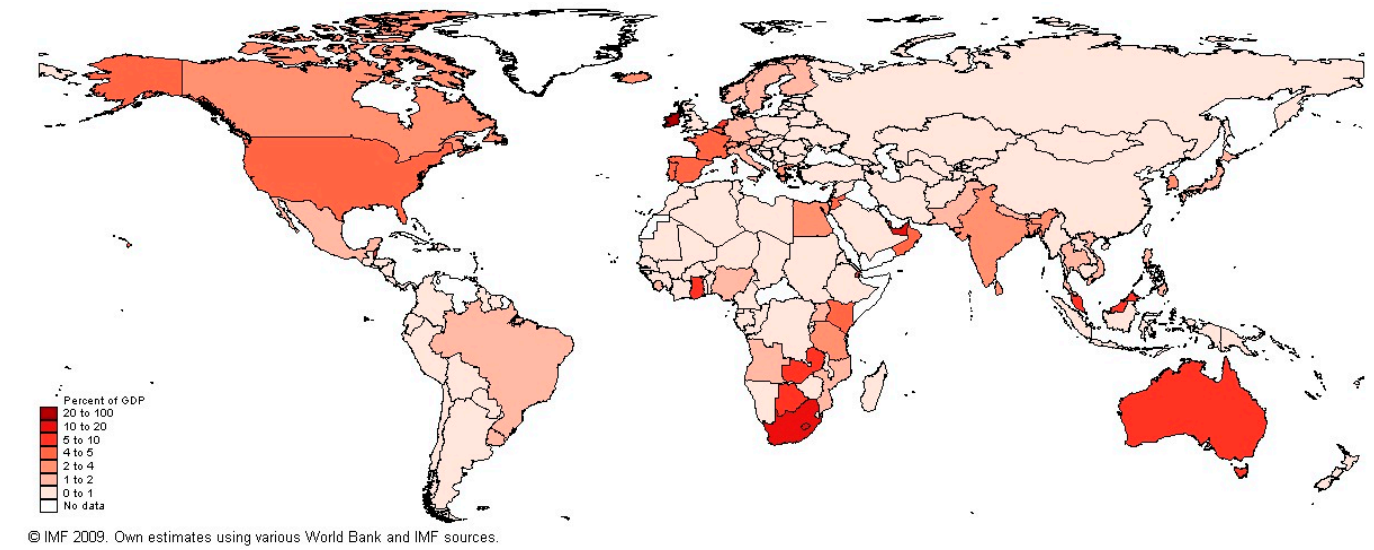

Source: IMF Research Department; based on BIS data as of end-December 2008.

The impact would be concentrated in Western Europe and the US, but leave few other countries unscathed. In absolute terms, the largest effects would be felt in advanced countries with globally integrated banking systems. Relative to domestic GDP, however, a sudden withdrawal of UK banks' credit would also weigh on a range of countries in Africa, Asia, and the Middle East. Reduced external credit to these countries, in turn, could set in motion a further deleveraging spiral.

Although a highly disruptive deleveraging is unlikely, its potential consequences heighten the need to restore stability in the UK financial system. The scenario considered here is illustrative. Crucially, its true global impact would depend on the nature of the underlying claims - with curbs in balanced interbank flows ultimately less damaging than a complete exit from overseas retail business - as well as on the speed of the credit withdrawal. Indeed, given the large-scale support provided by the UK authorities, a large-scale disorderly unwinding of foreign exposures should be viewed only as a tail risk. Nonetheless, the UK's close financial links with the rest of the world represent a key systemic vulnerability, highlighting the importance of successful stabilization now. 
25. There are signs of rising financial home bias globally, adding to the drop in credit supply in the UK. Both external claims and external liabilities of UK-owned financial institutions have declined over the last year, partially reflecting a reduction in cross-border interbank activity. At the same time, some foreign financial institutions have limited or closed their operations in the UK. The withdrawal of foreign (especially European) lenders from the UK market, combined with the drying up of global securitization markets, has accentuated the domestic credit squeeze.

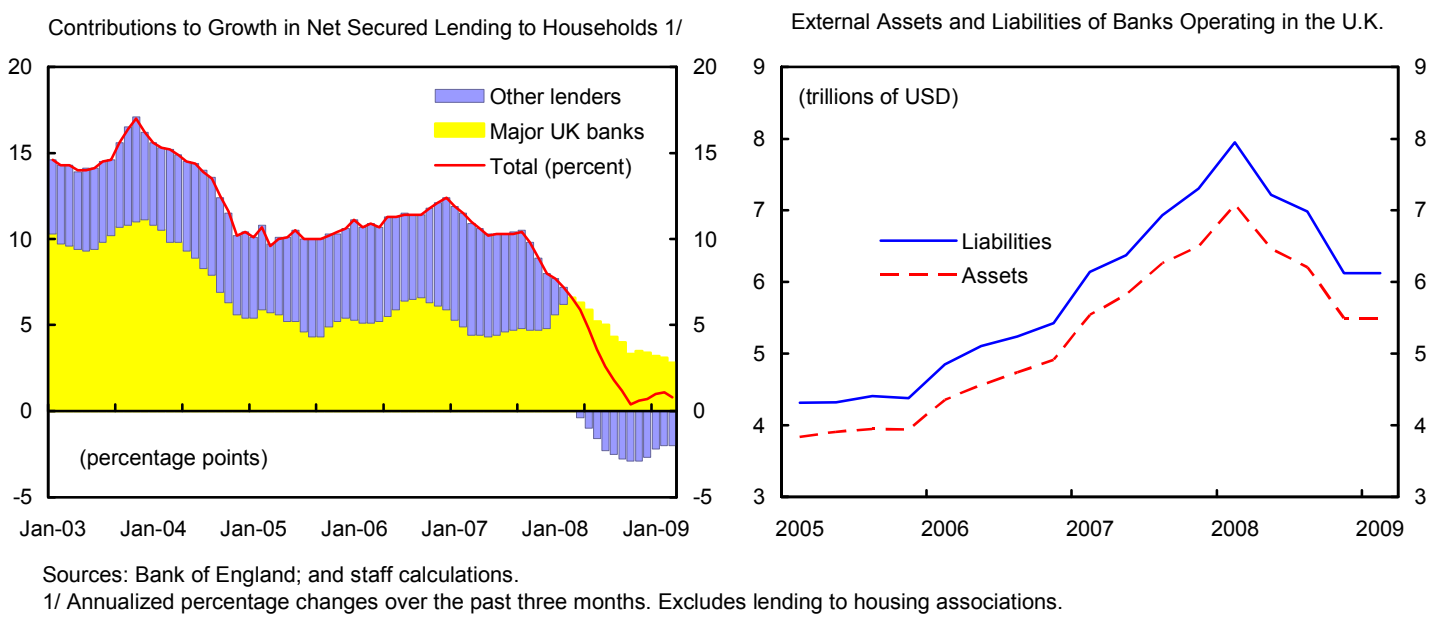

\section{THE OUTLOOK AND RISKS}

\section{A. Central Scenario}

\section{Output is expected to continue to contract in the near term, although at a}

decelerating pace. Private consumption growth is likely to remain negative in the coming quarters as households try to rebuild their savings in the face of uncertain employment prospects and declining net wealth. Business fixed investment weakness will persist against the background of weak demand, substantial spare capacity, and tight credit conditions. With housing prices still to find a bottom, near-term prospects for residential investment remain bleak. Net exports should GDP Growth Forecasts

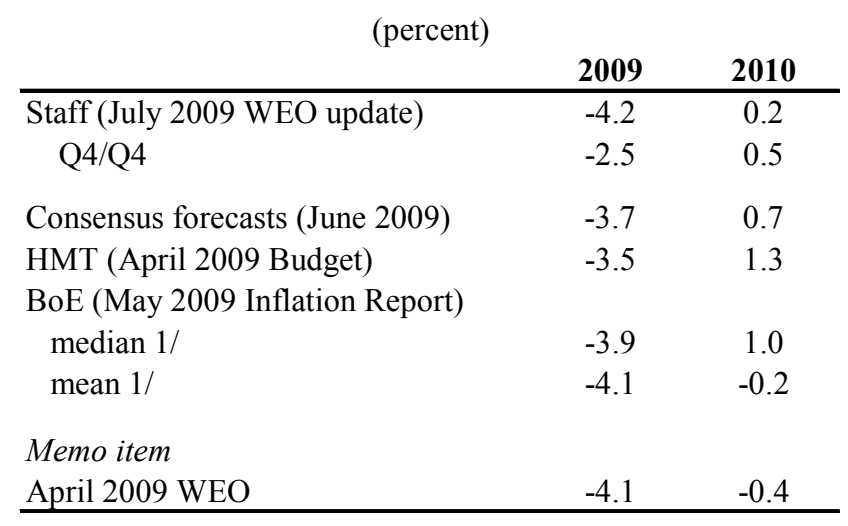
continue to provide a boost to growth, 1/ Based on staff estimates supported by the substantial sterling depreciation. Inflation is projected to fall below the 2 percent target and remain low for some time (see section VII). Forward- 
looking indicators have improved in recent months, but are still at levels suggesting a continuing decline in activity (Figure 1).

27. The recovery is likely to be gradual (Table 5). The UK economy entered the recession with sizeable imbalances, which will take time to be reduced. Moreover, research suggests that recessions linked to financial crises are deeper and last longer than other recessions, due to negative feedback effects between the real and financial sectors. ${ }^{3}$ The synchronized global recession is also likely to make it more difficult for any one country to grow out of its problems through exports. In the central projection, the economy recovers slowly_quarterly growth rates return firmly to positive territory only in early 2010, and growth does not reach its potential rate until 2011. With the inventory cycle bottoming out in the first quarter, it is possible to get a "doubledip" growth path, with stronger rebound Cumulative Change in GDP from Pre-Recession Peak, 1973-2012

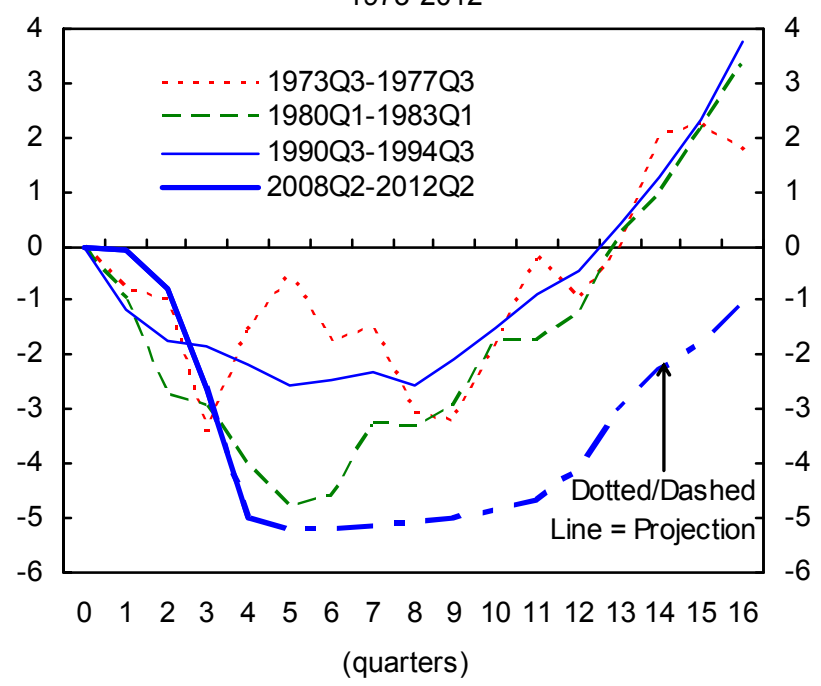

Sources: Office of National Statistics and staff estimates. in mid-2009, followed by some weakness later in the year.

\section{The financial crisis has affected not just the demand side, but also the productive capacity of the economy.}

Factors that would reduce potential supply include: a decline in the rate of capital accumulation as business investment falls and accelerated restructuring makes some capital obsolete; a decline in labor participation and a reduction in net migration flows; a decline in productivity as spending on research and development falls and financing of risky projects becomes more scarce. Staff estimates suggest that

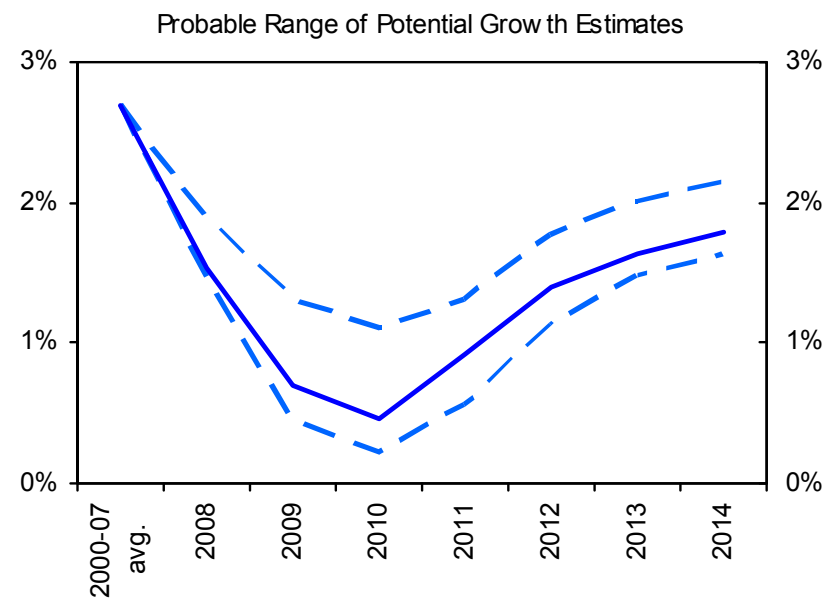

\footnotetext{
${ }^{3}$ See, for example, Reinhart, C. and K. Rogoff (2009) "The Aftermath of Financial Crises", NBER Working Paper 14656, Claessens, S., A. Kose, and M. Terrones (2008) "What Happens During Recession, Crunches and Busts?" IMF Working Paper 08/274, and World Economic Outlook (April 2009).
} 
the cumulative loss of potential output over 2008-10 could be as large as 4 to 5 percentage points (the 2009 Budget has assumed a similar loss of output). In the medium term, the potential growth rate may be $1 / 2$ to $3 / 4$ percentage point below the pre-crisis trend growth (see Annex III).

\section{B. Risks and Underlying Vulnerabilities}

\section{Uncertainty around the central scenario is substantial, given the} unprecedented nature of the crisis and the importance of confidence effects. The crisis has been characterized by a wide-spread loss of confidence and a high degree of uncertainty about the outlook. Future economic developments would depend largely on the success of policy actions in restoring confidence and putting the financial sector on a sound footing. The central projection reflects staff's view on the likely outcome, based on current policies. The risks around this projection are broadly balanced:

- The key uncertainty is the pace and extent of adjustment of bank and household balance sheets. The high level of household indebtedness is likely to constrain the pace of economic recovery as consumers retrench spending to reduce debt and rebuild savings. With the economic downturn heightening the risk of further large credit losses, banks have tightened the supply of credit. It remains to be seen whether the recent efforts to recapitalize banks will be sufficient to sustain credit provision at levels required for a robust economic recovery, and whether capital market funding can adequately compensate for shortfalls in bank loans.

- On the upside, with significant monetary and fiscal stimulus in train, a successful stabilization of the financial sector, a durable recovery of asset prices, and a fasterthan-expected pick up of global activity could restore confidence of economic agents and set the economy on a path to rapid recovery. The large inventory decline over the past six months could be a sign that adjustment is proceeding more rapidly than in the baseline and robust growth could resume toward the end of 2009.

- On the downside, greater-than-expected realized credit losses could result in further deterioration of the health of the financial sector, leading to more credit contraction and a deeper downturn. A substantial further decline of asset prices would hurt balance sheets even more, dampening consumption, investment, employment, and exacerbating the strains in the financial system. Meanwhile, a sharper-than-envisaged contraction of foreign demand would lead to a further fall in exports. An increasing home bias in financial and other services may reduce demand for UK services abroad.

\section{Notwithstanding recent signs of stabilization, the UK economy's resilience to}

potential shocks is not yet assured. The sharp increase in public sector borrowing and contingent government liabilities, together with continued financial sector fragility, are significant vulnerabilities. If there was a renewed and abrupt loss of confidence, possibly triggered from outside the UK, it could spark further financial sector instability, undermine faith in fiscal sustainability and unhinge inflation expectations, thus disrupting domestic 
and external stability. Although the probability of such a crisis is low, its impact could be substantial, highlighting the need for credible and consistent policies to limit downside risks and strengthen market confidence. The main policy priorities are:

- First, continued emphasis on resolving the problems in the financial sector to support stability and promote normalization of credit supply.

- Second, setting monetary and fiscal policies consistent with a firm commitment to the existing policy objectives of price stability and fiscal sustainability.

The authorities were in broad agreement with this assessment of vulnerabilities, but stressed that current and planned policy actions consistent with the priorities noted above truncate such tail risks. They noted that the effectiveness of their own efforts in these areas would be enhanced if they are complemented by coordinated multilateral action to rebalance global demand and achieve more sustainable external positions across countries.

\section{REPAIRING THE Financial SySTEM}

\section{Wide-ranging policy measures have helped forestall a systemic breakdown.}

The initial rescue package in October 2008 introduced large-scale guarantees of bank liabilities and an initial round of public capital injection in several large banks. The Bank of England expanded the special liquidity scheme, eased collateral requirements on open market operations, revamped its emergency lending facilities, and provided banks with significant amounts of US dollar funding under a swap line with the US Federal Reserve. Informed by detailed examinations and stress tests for key banks, a second set of measures, announced in early 2009, included new capital injections and an Asset Protection Scheme (APS), designed to ring-fence bad assets and provide contingent capital. ${ }^{4}$ Guarantee schemes for bank debt and asset-backed securities and support for new lending have also been introduced.

\section{Efforts to improve liquidity and strengthen capital were complemented by} regulatory measures. A higher ceiling on retail deposit insurance was introduced in October 2008, and a new Special Resolution Regime for dealing with failing banks was legislated in February 2009. ${ }^{5}$ In addition, resources for the supervision of systemically important institutions have been increased.

\footnotetext{
${ }^{4}$ The FSA stress test assumes a peak-to-trough fall in output of over 6 percent, unemployment rising above 12 percent, and cumulative declines in residential/commercial real estate prices of 50/60 percent. http://www.fsa.gov.uk/pages/Library/Communication/PR/2009/068.shtml

${ }^{5}$ Since the beginning of the crisis, two medium-sized banks have been nationalized (Northern Rock and Bradford and Bingley). Meanwhile, two other banks (HBOS and Alliance and Leicester) and several building societies have been taken over by stronger institutions.
} 


\section{A. Restoring Credit Flows}

33. However, the financial system may not yet be repaired to a level where banks are ready to increase lending sufficiently to underpin a strong recovery (see Box 2). Large uncertainties remain about the value of existing distressed assets and the adverse impact of the recession on credit quality. Although, based on the recent stress tests, banks are expected to continue to maintain a ratio of core tier 1 capital to risk weighted assets above 4 percent, substantial further write-downs would lead to an erosion of capital buffers. A considerably weaker and more prolonged recovery than currently envisaged may even lead to renewed doubts about the adequacy of capital in individual banks. These lingering uncertainties are restraining lending.

\section{Only sufficiently large capital buffers, if necessary provided by the} government, would enable banks to resume normal credit activities. With capital under pressure, banks may become too risk averse and limit credit extension. Conversely, some banks might be tempted to take on excessive risk in "a gamble for resurrection". To strengthen capital cushions and further mitigate risks, the authorities should:

- Encourage banks to take advantage of improving market conditions to augment their capital base, and also stand ready to provide further public support where needed.

- Promote options to preserve capital cushions and improve capital structures, for example by restraining dividends not supported by profits, and if necessary converting preference shares to common shares.

- Continue the development of contingency plans in the event that further shocks threaten the stability of financial institutions. For banks with strong cross-border links, this effort will require greater international coordination based on the Financial Stability Board's principles of crisis management.

The authorities explained that the main goal of recent rescue packages was to increase capital to levels sufficient to restore stability. In choosing their actions, they had to balance a number of sometimes conflicting objectives, such as restoring confidence, containing taxpayers' costs, protecting property rights, limiting the extent of government involvement in the financial sector, and respecting European competition law. The authorities also pointed out that stress tests do not provide a binary outcome and that the situation remains under review, and they remain committed to taking all necessary actions to ensure stability.

35. Detailed information should be released on the pool of assets covered by the APS once the contracts are finalized. That should reduce uncertainty as market participants will be able to evaluate better the balance sheet strength of institutions participating in the scheme. With respect to management of the assets protected by the APS, disposal through a bad bank arrangement should remain under consideration as one of the resolution options. 


\section{While banks go through a difficult but necessary balance sheet restructuring, additional efforts to support credit supply are warranted in the short term. The} targeted intervention in dysfunctional credit markets through the BoE's Asset Purchase

\section{Box 2. Capitalization of the UK Banking System}

Estimates of capital needs are inherently uncertain, depending among others on the chosen benchmark for capital sufficiency and on macroeconomic assumptions, asset price developments, and revenue strength. These methodological challenges are compounded by incomplete information on balance sheet structure, asset quality, and collateral positions. With these limitations in mind, staff has estimated UK banks' capital needs using two different approaches.

The April 2009 GFSR applied a top-down approach based on stylized balance sheets. The results suggest that at end-2008 the UK banking system would need $£ 88$ billion (US\$125 billion, or about 6 percent of GDP) in fresh equity to reach a target leverage ratio of 4 percent. To complement this estimate, the UK mission team conducted a separate bottom-up analysis considering specific loss rate scenarios for broad asset categories across individual bank balance sheets. The median estimate of that analysis is in line with the GFSR result.

Measured against the staff's numbers, actual capital raising from private and public sources has fallen short. Nonetheless, the authorities are confident that there will not be a need for further large-scale government support beyond the steps already taken: two banks, RBS and Lloyds, received a $£ 37$ billion public capital injection in October 2008, and an additional injection of $£ 35$ billion in nonvoting B-shares is pending in conjunction with the Asset Protection Scheme (APS) announced in the first quarter of 2009. The authorities' assessment is based on bank-bybank stress tests. Accordingly, all systemically relevant large UK banks will be sufficiently capitalized to maintain a core tier 1 ratio above 4 percent even under stress over a five year time horizon.

What accounts for the difference between staff's estimates of capital needs and the authorities' stress test results?

- Capital benchmark: Staff defined target capitalization levels by a simple leverage ratio (tangible equity over tangible assets) of 4 percent. By contrast, the FSA's stress tests used the core tier 1 ratio. This measure includes the APS-related B-shares as capital in the numerator and applies risk weights to the assets in the denominator, which together raises the capitalization ratio. Staff's choice of a simple leverage ratio reflects a conservative approach, given concerns about sometimes inappropriately low risk weights and limited loss absorption provided by forms of bank capital other than equity. It also reflects informational constraints. 


\section{Box 2. Capitalization of the UK Banking System (continued)}

- Impact of APS: Staff's bottom-up estimates anticipate the explicit provision of new capital under the APS but do not capture the contingent capital feature of the scheme. Once contracts are finalized, the APS will protect RBS and Lloyds from extreme losses on $£ 325$ billion and $£ 260$ billion of exposures respectively, as the two banks would bear only 10 percent of losses beyond first-loss amounts of $£ 42$ billion and $£ 35$ billion. ${ }^{1}$ While this clearly reduces the risk associated with the insured assets, staff's estimates do not reduce the total assets by the level of the protected assets, nor do they adjust equity for the banks' first loss commitments.

- Granularity of information: For its bottom-up exercise, staff used detailed bank-by-bank information on balance sheet exposures from the largest banks' financial statements. However, published information did not provide in every case a very detailed breakdown of assets into precise risk categories. These data constraints made it necessary to use somewhat crude assumptions on loss rates in various asset classes.

- Existing commitments: The authorities' stress tests may give some credit for unannounced bank plans to reduce leverage through asset divestitures or specific capital measures. Such prospective steps are not taken into account in staff's estimates.

Staff's overall judgment, based on discussions with the authorities, is that capital bases now appear strong enough to avert a renewed systemic crisis. Nevertheless, uncertainty remains about the speed and strength of recovery. A particularly slow or weak recovery has the potential to cycle back on funding and credit conditions, which may reintroduce doubts about bank capital levels. There is a case, therefore, for erring on the side of caution and seeking a further strengthening of banks' capital positions. Larger capital cushions will also afford greater lending capacity to underpin the economic recovery.

${ }^{1}$ First loss amounts are inclusive of existing provisions.

Facility is welcome. Lending guarantee schemes are also appropriate as long as they are designed to support viable new lending. In the current circumstances, bank-specific lending commitments, as envisaged by the authorities, can serve as a useful coordination device to avert a credit crunch, provided there are safeguards to ensure that new lending is done on commercial terms and under sound risk management practices.

37. More generally, measures should be geared at facilitating orderly deleveraging of balance sheets, rather than preventing the necessary adjustment. It is important to acknowledge that financial sector activity and lending growth may not revert to their precrisis pace for some time, if at all.

\section{B. Regulatory Response}

\section{Beyond the short-term firefighting, the crisis has highlighted the need for} strengthening the UK's prudential framework. The UK's approach was premised on the 
belief that markets are in general self-correcting, with market discipline and the responsibility of senior management of firms to manage risks being more effective tools than regulation or supervisory oversight, dubbed by some as a "light-touch" approach. Recognizing the deficiencies of this approach, the FSA has moved to more aggressive, hands-on supervision. The funding of the FSA has been strengthened and greater resources are allocated to the assessment of large financial institutions and the evaluation of systemic risk.

\section{The new Special Resolution Regime will facilitate interventions in troubled} financial institutions. The February 2009 Banking Act provides the legal framework for expeditious resolution of failing financial institutions (including large cross-border banks). Its effectiveness will require timely and comprehensive information sharing among the tripartite authorities. The increased reliance on stress tests as a tool for higher frequency evaluation of individual banks and the financial system resilience is welcome.

\section{The Turner Review represents an important contribution to the international} debate on reform of the regulatory and oversight system for financial institutions. The Review appropriately calls for higher capital requirements within a risk-based capital framework for trading book and off-balance sheet assets and for the introduction of a maximum leverage ratio as a backstop against excessive growth in balance sheets. The proposed strengthening of liquidity supervision, with a special emphasis on stress tests covering system-wide risks, is also appropriate. These measures should be complemented by the development of new macro-prudential instruments to mitigate the amplitude of the credit cycle and reduce feedback loops between the financial sector and the real economy. In addition, as emphasized in the Review, regulatory and supervisory coverage should follow the principle of economic substance, not legal form. Regulators should have expanded powers to gather information on all significant financial institutions (including hedge funds) to allow assessment of overall system-wide risks.

\section{Improved disclosure practices would reduce uncertainty and strengthen} market discipline and public surveillance. Specifically, there would be merit in increasing the coverage and frequency of financial reporting on banks' finances. The UK lags behind a number of G-20 countries in this area (see text table). Financial institutions should be encouraged to provide comparable and more comprehensive disclosure of financial results at quarterly intervals (RBS released an interim management statement in the first quarter of 2009, which could serve as an example of good quarterly disclosure for other banks). Over the medium term, the authorities should consider publishing noncommercially sensitive bank-by-bank regulatory financial information, also at quarterly intervals. Such increased transparency would improve consistency and comparability of financial reporting that will facilitate monitoring of risks by investors and counterparties. The FSA pointed out that increased disclosure entails costs that have to be weighed against the potential benefits. 
G20: Disclosure Practices for Banks

\begin{tabular}{|c|c|c|c|c|c|c|}
\hline \multirow[b]{2}{*}{ Country } & \multirow{2}{*}{$\begin{array}{c}\text { Published Results of Listed Banks } \\
\text { Frequency }\end{array}$} & \multicolumn{5}{|c|}{ Availability of Regulatory Reporting to the Public } \\
\hline & & Frequency & Bank-by-bank & Aggregate & $\begin{array}{c}\text { Balance } \\
\text { Sheet }\end{array}$ & $\begin{array}{c}\text { Income } \\
\text { Statement }\end{array}$ \\
\hline Argentina & Quarterly & Monthly & $\sqrt{ }$ & & $\sqrt{ }$ & \\
\hline Australia & Mixed & Monthly & $\sqrt{ }$ & & $\sqrt{ }$ & \\
\hline Brazil & Quarterly & Monthly & $\sqrt{ }$ & & $\sqrt{ }$ & $\sqrt{ }$ \\
\hline Canada & Quarterly & Monthly/quarterly & $\sqrt{ }$ & & $\sqrt{ }$ & $\sqrt{ }$ \\
\hline China & Quarterly & Quarterly & & $\sqrt{ }$ & & \\
\hline France & Mixed & Monthly & & & $\sqrt{ }$ & \\
\hline Germany & Mixed & Monthly & & $\sqrt{ }$ & $\sqrt{ }$ & \\
\hline India & Quarterly & Annual & $\sqrt{ }$ & & $\sqrt{ }$ & \\
\hline Indonesia & Quarterly & Monthly & & $\sqrt{ }$ & $\sqrt{ }$ & $\sqrt{ }$ \\
\hline Italy & Quarterly & Quarterly & & $\sqrt{ }$ & $\sqrt{ }$ & \\
\hline Japan & Mixed & Monthly & & $\sqrt{ }$ & & \\
\hline Mexico & Quarterly & Monthly & $\sqrt{ }$ & & $\sqrt{ }$ & $\sqrt{ }$ \\
\hline Norway & Quarterly & Quarterly & $\sqrt{ }$ & $\sqrt{ }$ & $\sqrt{ }$ & $\sqrt{ }$ \\
\hline Russia & Quarterly & Monthly & & $\sqrt{ }$ & $\sqrt{ }$ & \\
\hline Saudi Arabia & Quarterly & Quarterly & & $\sqrt{ }$ & $\sqrt{ }$ & \\
\hline South Africa & Semi-annual & Monthly & $\sqrt{ }$ & & $\sqrt{ }$ & $\sqrt{ }$ \\
\hline Spain 1/ & Quarterly & Quarterly & $\sqrt{ }$ & & $\sqrt{ }$ & $\sqrt{ }$ \\
\hline South Korea & Quarterly & Quarterly & $\sqrt{ }$ & & $\sqrt{ }$ & $\sqrt{ }$ \\
\hline Turkey $1 /$ & Quarterly & Quarterly & $\sqrt{ }$ & & $\sqrt{ }$ & $\sqrt{ }$ \\
\hline United Kingdom & Semi-annual & Quarterly & & $\sqrt{ }$ & $\sqrt{ }$ & $\sqrt{ }$ \\
\hline United States & Quarterly & Quarterly & $\sqrt{ }$ & & $\sqrt{ }$ & $\sqrt{ }$ \\
\hline Total Results & & & 12 & 9 & 19 & 11 \\
\hline
\end{tabular}

42. Special emphasis should be given to working with international partners to strengthen cross-border financial stability arrangements. This will require continued collaboration on the development of effective arrangements for crisis management and orderly exit of cross-border banks, including accelerated efforts to establish a dedicated resolution framework for the EU's cross-border banks. In addition, working with partner countries to implement quickly the proposed ambitious overhaul of the EU's regulatory and supervisory arrangements is a priority. ${ }^{6}$ Securing adequate resources, effective decisionmaking mechanisms, independence for the new institutions, and an unconstrained flow of information among the various bodies will be essential for the effectiveness of the proposed new architecture.

\section{Monetary Policy in Unconventional Territory}

\section{A. The Outlook for Inflation}

\section{Inflation is set to continue falling and remain below target for some time.}

Although 12-month CPI inflation is currently still slightly above the 2-percent target, it is projected to fall to 1 percent later in 2009 as domestic energy cost pressures ease and rising spare capacity weakens firms' pricing power and workers' wage demands (Figure 9).

\footnotetext{
${ }^{6}$ Specific suggestions along those lines are discussed in more detail in the forthcoming Staff Report for the 2009 Article IV Consultation with member countries of the euro area.
} 
Figure 9. Price Developments, 2004-09

After peaking in mid-2008, inflation has eased markedly in recent months...

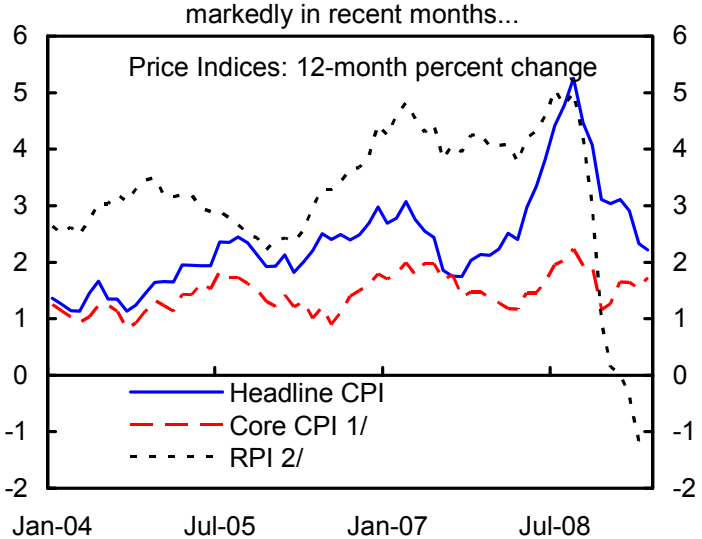

..which has taken pressure off import and producer prices, despite the significant currency weakening.

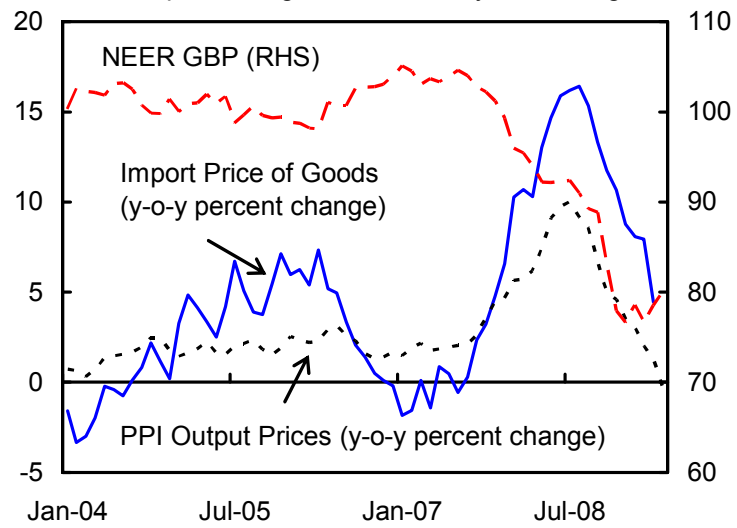

...and broad money growing at a very subdued pace, despite the expansion of base money...

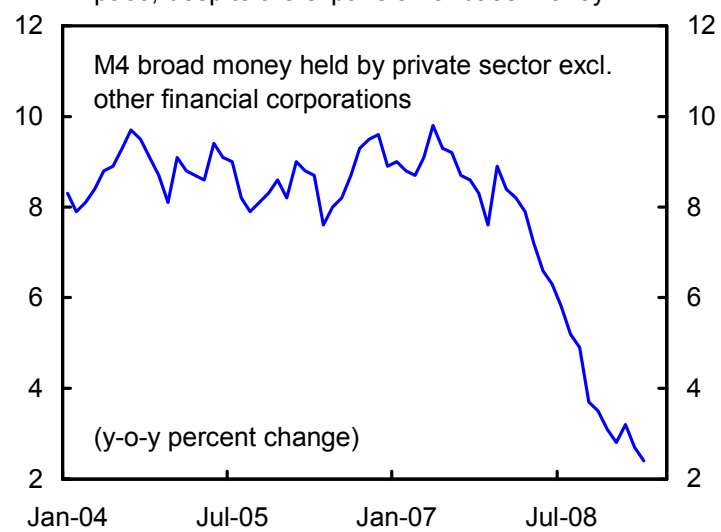

...reflecting the economic slowdown coupled with a sharp drop

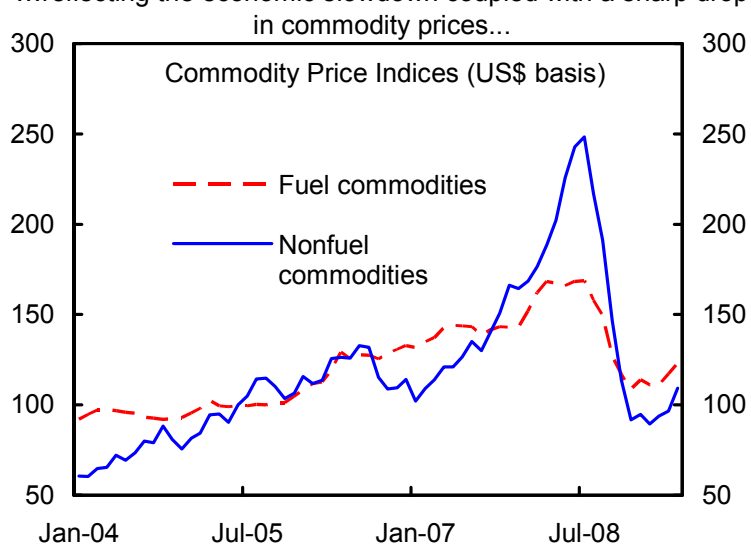

With labor costs also moderating of late...

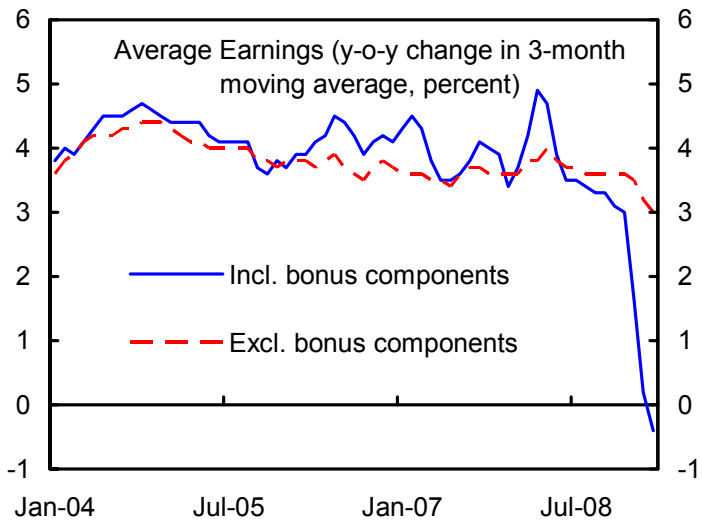

...there has been some concern about near-term deflation, although medium-term expectations remain well-anchored.

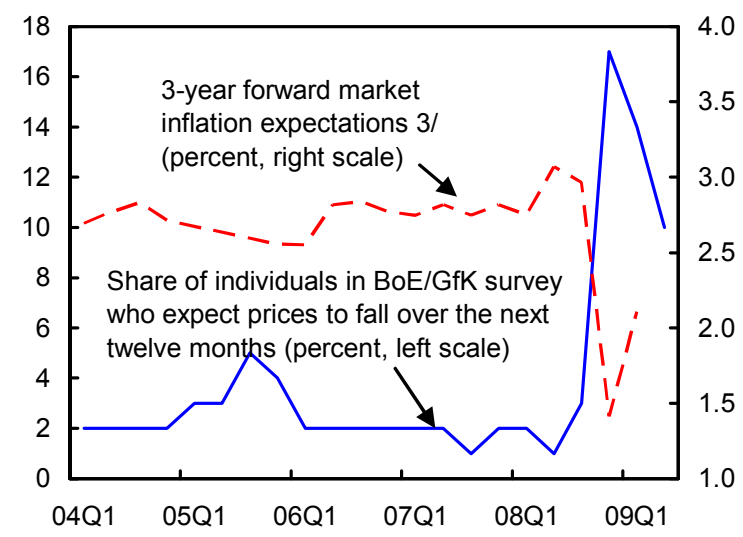

Sources: Bank of England; UK Statistical Office; and IMF, Commodities Database.

1/ Core CPI excludes energy, food, alcohol, and tobacco.

2/ Retail Price Index; contains cost of housing.

$3 /$ Computed as quarterly average of difference between nominal and real (RPI-linked) forward gilt yields. Estimates likely to be biased upward by the presence of an inflation risk premium, and downward by the liquidity risk premium on real gilts. 
Looking further ahead, the expected slow recovery should keep inflation below target for an extended period. However, as noted in the May 2009 Inflation Report, the outlook is subject to significant uncertainties. On the one hand, experience from historical banking crises suggests the possibility of even more protracted disinflation if very weak demand conditions persist. A slip into outright deflation is unlikely but cannot be ruled out in this case. ${ }^{7}$ On the other hand, there are some upside risks, related to the pass-through of exchange rate weakness and a stronger-than-expected rebound in global commodity prices.
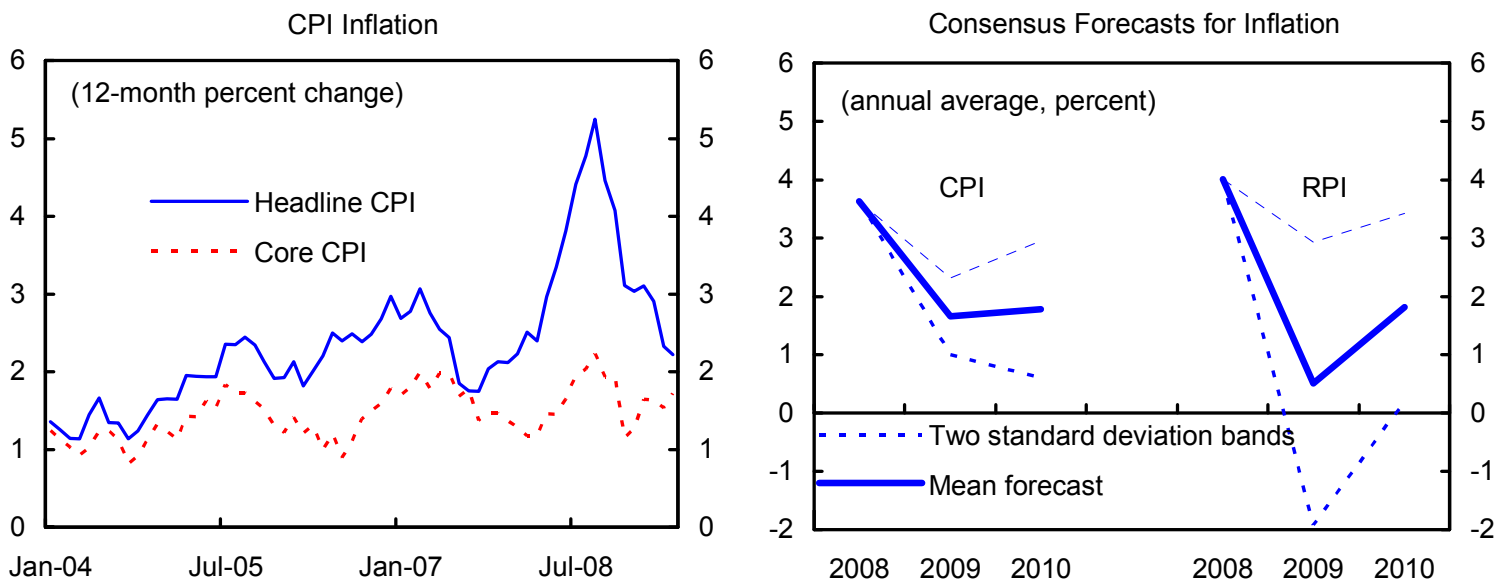

Sources: Office for National Statistics; Consensus Forecast June 9, 2009; and IMF staff calculations.

\section{B. Launching Unconventional Easing Operations}

\section{Against this backdrop, the Bank of England has adopted an aggressive monetary strategy, including the launch of unconventional easing operations.}

- Bank Rate was reduced by a cumulative 450 basis points to 0.5 percent between October 2008 and March 2009. This level is expected to mark the floor for policy rates, as the MPC views lower rates as potentially counterproductive: many retail lending products are indexed to Bank Rate, and with deposit rates already close to zero, further Bank Rate cuts would squeeze lenders' interest margins and possibly further tighten credit supply.

- With Bank Rate at its lower bound, the MPC moved to "quantitative easing" (QE) in March 2009. Under this policy, the BoE is on course to buy $£ 125$ billion in assets through its Asset Purchase Facility - out of $£ 150$ billion initially authorized by the Treasury - within five months, financed by an expansion of base money. The

\footnotetext{
${ }^{7}$ One traditional measure of UK inflation, the Retail Price Index (RPI), has actually dipped into negative territory in recent months. However, this is largely accounted for by the sharp drop in mortgage interest rates, which are included as a proxy for housing costs in the RPI but not the CPI.
} 
purchases are concentrated on long-term gilts, reflecting the Bank's goal to inject large amounts of liquidity into private portfolios without assuming credit risk. However, the BoE is also buying selected high-quality private assets, notably commercial paper and corporate bonds, with a view to improving the functioning of these markets. The overall volume of purchases is quantitatively important in relation to the initial monetary base (some $£ 90$ billion) as well as the stock of relevant assets outstanding (see also Annex IV for an international perspective on central bank asset purchases).

Bank of England Balance Sheet (Billions of Sterling)
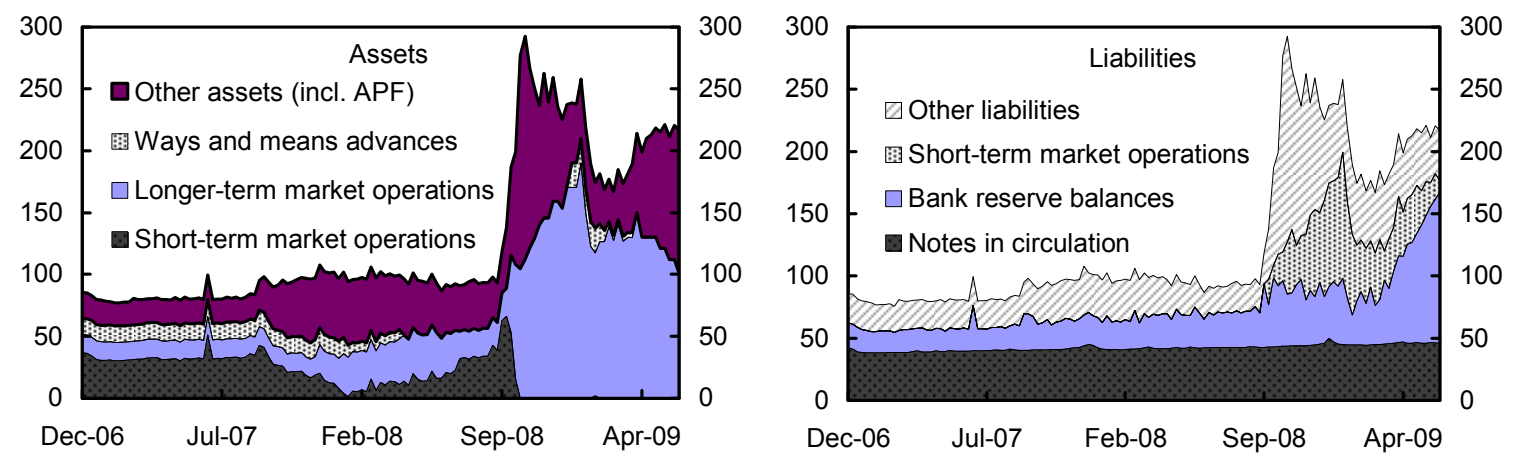

Source: Bank of England.

45. The BoE's aggressive easing has been timely and appropriate. The current combination of high household debt, weak asset prices, fragile banks, and faltering demand has potentially strong disinflationary effects. Sharp unexpected disinflation, in turn, could amplify the downturn through its impact on debtor balance sheets. These risks justify forceful preventive policy action. The move to unconventional easing logically extends the monetary stimulus at the lower bound for policy rates, especially as the expansionary impact of rate cuts has been muted by the large risk premia and generalized tightening of supply in private credit markets. In one tentative sign of success, the BoE's policy actions have kept medium-term inflation expectations broadly on target thus far.

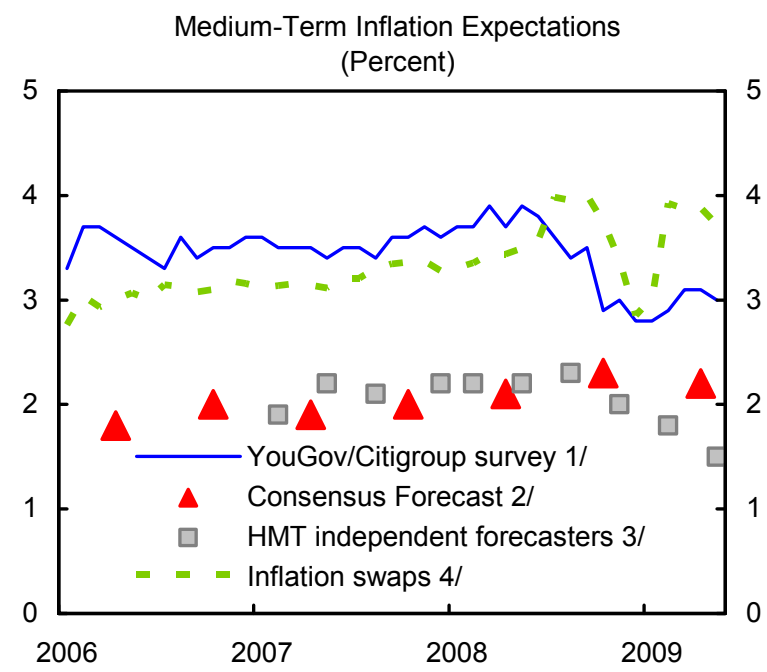

Sources: YouGov; Consensus Economics; HM Treasury; Bloomberg; and IMF staff calculations. $1 /$ Inflation five to ten years ahead.

2/ CPI inflation in 2015.

3/ CPI inflation in 2011

4/ 5-year forward RPI inflation inferred from inflation swaps. 


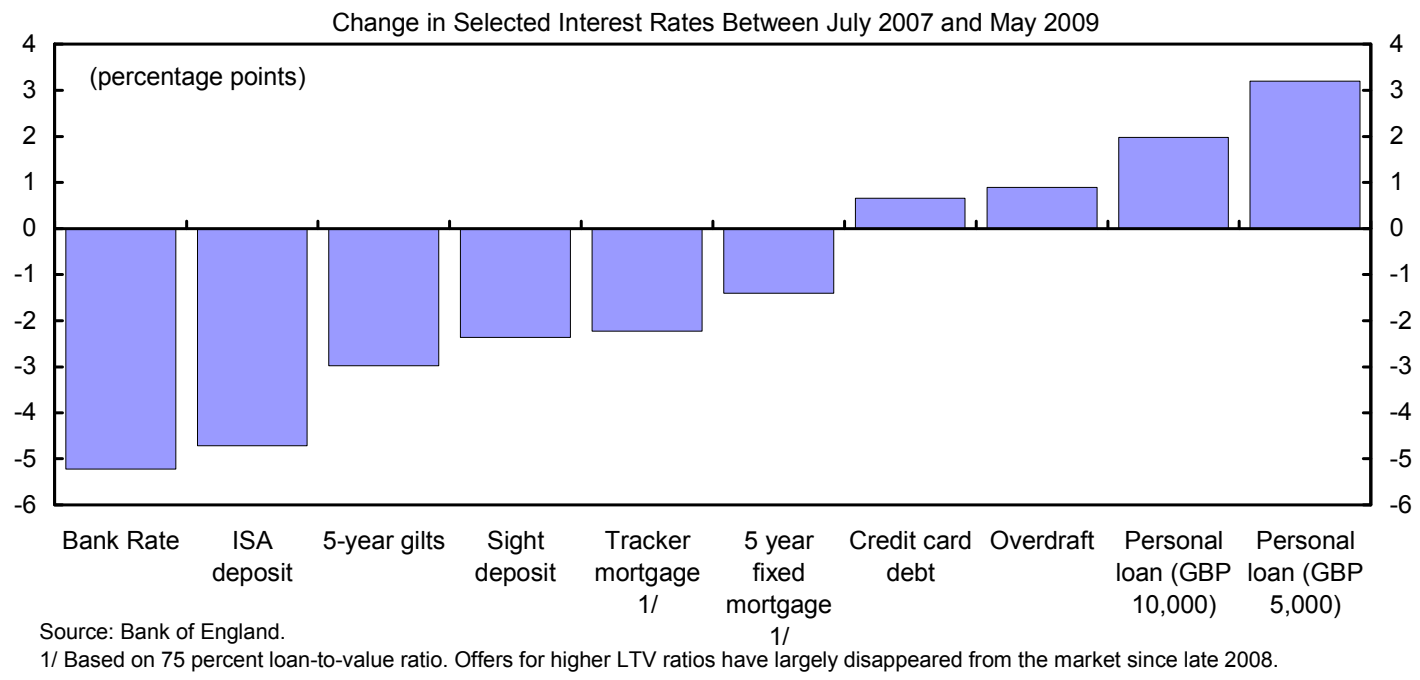

46. However, it is yet too early to judge the effectiveness of QE. In principle, the significant liquidity injection should induce investors to rebalance their portfolios, thus lifting asset valuations, generating positive wealth effects, and facilitating new issuance. Targeted purchases of private assets can complement these effects by directly reducing excessive risk premia and reviving market activity. The initial evidence has been moderately encouraging as gilt yields have remained low since the launch of QE, despite the countervailing effect of large new government debt issuance. Meanwhile, spreads on commercial paper and corporate bonds have narrowed, amid a broader recovery of asset prices. It remains to be seen, however, whether these effects will be sufficiently strong and lasting to generate the desired rise in aggregate demand. This uncertainty strengthens the case for further diversifying the BoE's asset purchases, especially by targeting private credit markets that are currently dysfunctional but deemed to be viable in the long run. The BoE noted that efforts in this direction were underway but that setting up appropriate facilities took time. In mid-June, it announced its intention to start buying certain types of asset-backed commercial paper.
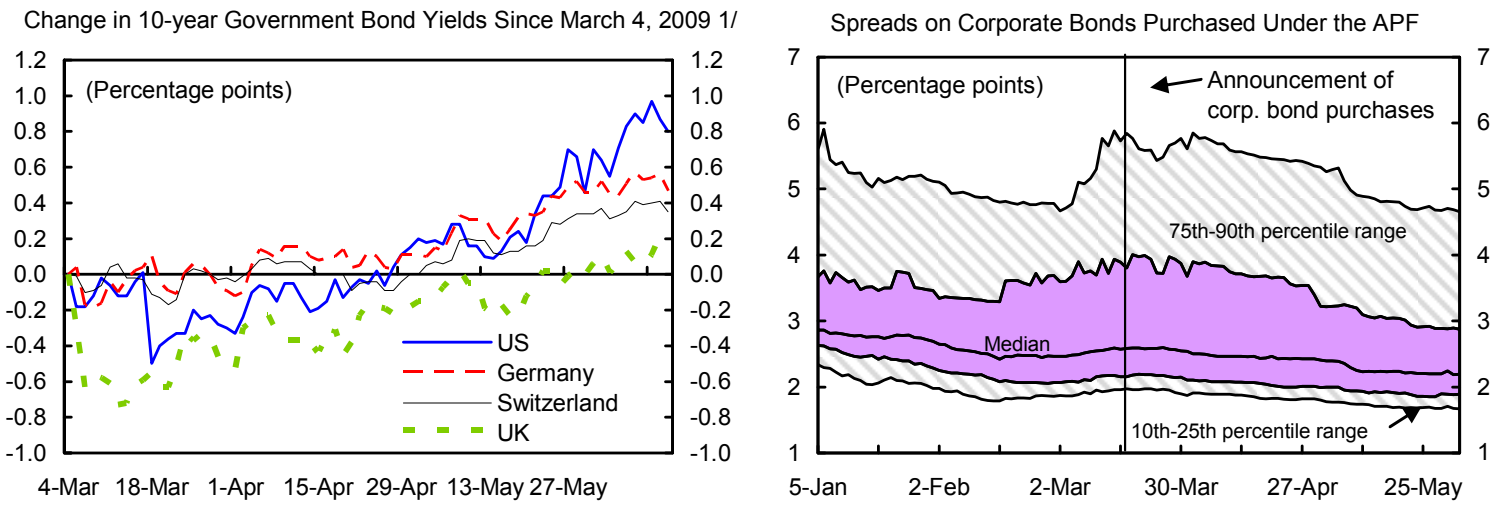

Sources: Bank of England; Bloomberg; and IMF staff calculations. 1/ The Bank of England announced the launch of large-scale gilt purchases on March 5, 2009. 


\section{Addressing Risks}

47. The success of QE rests on the BoE's capacity to keep monetary policy strictly focused on price stability. In this regard, the prudent setup of the Asset Purchase Facility, which operates as a separate legal entity under comprehensive indemnity assurances from the Treasury, is welcome. This arrangement protects the integrity of the BoE's balance sheet, a key prerequisite for independent monetary policy. In the same vein, it is reassuring that Treasury approval will not be required for the MPC to stop or unwind asset purchases in the future. This puts the MPC in a strong position to determine and implement an exit from QE as appropriate to meet the inflation target. To be sure, timing the exit will be a difficult judgment call, requiring vigilance in monitoring trends in monetary aggregates and inflation expectations. However, the exit should not pose major technical challenges as the BoE can rely on a combination of asset sales, other liquidity-draining operations, and higher interest rates. Clear communication by the BoE of its thinking on these aspects of QE would further underpin market confidence.

48. At a more fundamental level, trust in the BoE's operational independence hinges on the stability of public finances. Despite the prudent institutional setup of the Asset Purchase Facility, some observers have voiced concerns about a conflation of fiscal and monetary policies. Large-scale gilt purchases, in particular, risk being perceived as a slippery slope toward monetization of the UK's widening fiscal deficits. Countering such concerns, the government has reaffirmed its commitment to price stability, most recently in renewing the MPC's remit with respect to the 2-percent inflation target. However, to remove residual doubts and preserve full confidence in the UK's policy frameworks, sound communication and implementation of monetary policy ultimately needs to be underpinned by a sustainable path of fiscal policy.

\section{RESTORING FisCAL SUSTAINABILITY}

\section{The challenge facing the Treasury is to revitalize the financial sector and} support the economy, while committing credibly to long-term fiscal sustainability. With the private sector focused on raising savings and mending balance sheets, the government has the task of facilitating and smoothing the adjustment. This is not an easy task. The fiscal balance has deteriorated sharply and substantial deficits are projected for the medium term. In addition, contingent liabilities of the government from financial sector interventions have increased sharply. Against this background, the measured temporary fiscal stimulus implemented in the 2008 Pre-Budget Report and the 2009 Budget, together with free operation of the automatic stabilizers, is appropriate.

50. The 2009 Budget acknowledged transparently the scale of deterioration of the fiscal position. Of particular note, it comes to the conservative judgment that the structural component of the deficit is almost 10 percent of GDP, or about four-fifths of the total deficit in 2009/10 (Table 2 and text table). The authorities and staff agreed that, with asset 
prices and the level of financial activity likely to remain subdued in the medium term, some of the reduction in the revenue-to-output ratio is likely to persist even after the economy recovers. The budget envisaged a moderate consolidation, which would bring the cyclically-adjusted current account into balance by 2017/18. Net public sector debt is projected to peak in $2013 / 14$, consistent with the temporary operating rule. ${ }^{8}$ However, as acknowledged in the budget, there are substantial risks around the projected medium term fiscal path (Annex V). As bond yields tend to increase with debt levels, the burden of debt service may rise by more than expected. Should the recovery be slower than forecast, or should potential output fall more than envisaged, reducing the deficit would be even more challenging. Finally, potential losses from government guarantees and other contingent liabilities pose risks to the baseline debt projection, offset in part by the assumption that there is no recovery on past capital injections over the projection period.

United Kingdom: Selected Fiscal Indicators: Public Sector, 2007-2015

\begin{tabular}{|c|c|c|c|c|c|c|c|c|}
\hline & $2007 / 08$ & $2008 / 09$ & $2009 / 10$ & $2010 / 11$ & $2011 / 12$ & $2012 / 13$ & $2013 / 14$ & $2014 / 15$ \\
\hline & \multicolumn{8}{|c|}{ percent of GDP } \\
\hline & \multicolumn{8}{|c|}{ Budget 2009} \\
\hline Overall balance & -2.4 & -6.3 & -12.4 & -11.9 & -9.1 & -7.2 & -5.5 & $\ldots$ \\
\hline o/w Discretionary measures & & -0.6 & -1.5 & 0.3 & 0.8 & $\ldots$ & $\ldots$ & $\ldots$ \\
\hline Cyclically adjusted overall balance $1 /$ & -2.7 & -5.7 & -9.8 & -9.0 & -6.8 & -5.5 & -4.5 & $\ldots$ \\
\hline Fiscal stance $2 /$ & 0.6 & 3.0 & 4.0 & -0.8 & -2.2 & -1.3 & -1.0 & $\ldots$ \\
\hline Public sector net debt (excl. FS interventions) & 36.5 & 43.0 & 55.4 & 65.0 & 70.9 & 74.5 & 76.2 & $\ldots$ \\
\hline Public sector net debt (incl. unrealized losses from FS interventions) & 36.5 & 46.5 & 59.0 & 68.4 & 74.0 & 77.5 & 79.0 & $\ldots$ \\
\hline \multirow{2}{*}{ General government gross debt } & 43.2 & 55.4 & 71.9 & 82.1 & 87.2 & 89.9 & 90.7 & $\ldots$ \\
\hline & & \multicolumn{7}{|c|}{ Staff projections $3 /$} \\
\hline Overall balance & -2.4 & -6.1 & -12.8 & -13.1 & -10.4 & -8.6 & -7.0 & -6.2 \\
\hline Public sector net debt (excl. FS interventions) & 36.5 & 42.1 & 56.4 & 67.9 & 75.2 & 79.9 & 82.6 & 86.6 \\
\hline General government gross debt & 43.2 & 55.4 & 72.7 & 85.0 & 91.9 & 96.1 & 98.6 & 100.0 \\
\hline
\end{tabular}

\section{Despite the rise in net borrowing, rollover risks are limited by the long average} maturity of the public debt. The stock of UK debt has an average maturity of 14 years, higher than most OECD countries. Nonetheless, gross financing needs of the general government could reach 16 percent of GDP in 2009/10. ${ }^{9}$ The Debt Management Office has

\footnotetext{
${ }^{8}$ The temporary operating rule adopted in Pre-Budget 2008 aims "to set policies to improve the balance on the cyclically-adjusted current budget every year, once the economy emerges from the downturn, so it reaches balance and debt is falling as a proportion of GDP once the global shocks have worked their way through the economy in full."

${ }^{9}$ Standard and Poor's lowered its outlook on UK public debt from stable to negative in May 2009, citing the prospect of debt reaching very high levels, even after factoring in some fiscal tightening. In the press release, it was noted that further rating action would depend on the credibility of the next government's fiscal consolidation plans.
} 
recently added syndication to its tools to facilitate placement and ensure investor demand along the entire yield curve.
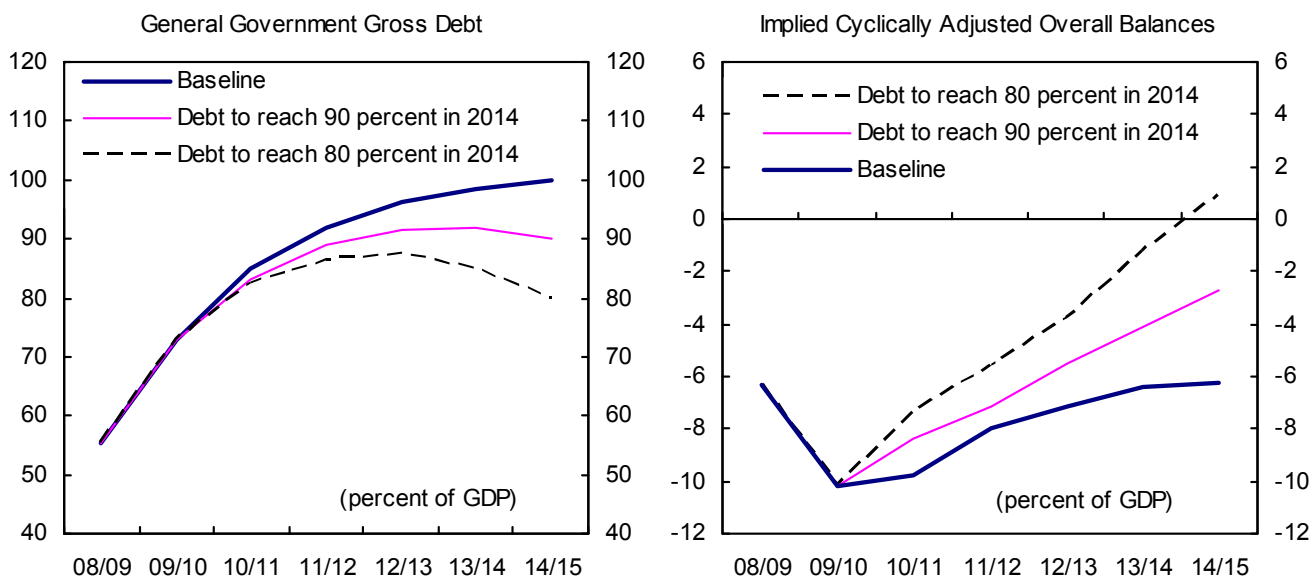

52. Going forward, a strong commitment to medium-term fiscal consolidation is crucial. Indeed, the success of the current policy package hinges on the trust of the public in the solvency of the government. Should fiscal sustainability come into question, interest rates would rise despite monetary easing efforts, the ability of the government to provide support to the financial sector would be severely limited, and pressures on the currency could emerge. To limit such risks and increase resilience to shocks, the authorities need to commit to a credible plan to reverse the deterioration of the fiscal position in the medium term and build a broad public consensus around a concrete consolidation plan. Restoring fiscal sustainability should be supported by the following steps:

- Once the economic recovery is established, a more ambitious fiscal adjustment should be implemented. The focus of this adjustment should be to put public debt on a firmly downward path faster than envisaged in the 2009 budget. In the current framework, public debt can reach very high levels while the temporary fiscal rule is still satisfied. It would be appropriate to put greater emphasis on stabilizing the debt at a relatively low level within a reasonable time frame. This will require a significant fiscal effort. For example, based on staff's projection, achieving general government gross debt of 90 percent of GDP by 2014/15 (compared to 100 percent of GDP in the baseline) would require $1 \frac{1}{2}$ percentage points average improvement in the cyclically-adjusted overall balance per year (compared to $3 / 4$ percentage points in the baseline). The authorities noted that the fiscal adjustment path would be reassessed as economic circumstances change.

- The adjustment paths outlined above are illustrative examples. More important than a specific medium-term fiscal goal is the credibility of consolidation plans. Credibility would be enhanced by providing greater clarity on the specific revenue and expenditure measures to achieve the needed adjustment. The emphasis in current plans to weigh the 
- adjustment toward expenditure reduction is appropriate in light of international experience that expenditure-based consolidations are more durable (Box 3), although given the size of the adjustment, revenue measures would also be necessary. The forthcoming Comprehensive Spending Review would provide an opportunity for committing to concrete expenditure measures.

- Any upside surprises to growth or revenue should be used to reduce deficits more aggressively.

- Interventions in the financial sector should be unwound gradually, with a goal of minimizing market disruptions and taxpayers' costs.

- Long-term sustainability would be strengthened by implementing structural reforms to address the rising costs related to demographic change, especially in health care.
UK: Increase in Age-related Government Expenditure (Percent of GDP)

\begin{tabular}{lcc}
\hline & $2007-2035$ & $2007-2060$ \\
UK & 2.7 & 5.1 \\
Euroa Area & 3.2 & 5.2 \\
EU-25 & 2.7 & 4.7 \\
\hline
\end{tabular}

Source: EU Commission, Aging Working Group (2009). 


\section{Box 3. Fiscal Adjustment: International Experience}

The timing, speed and size of fiscal adjustment are important for its success. ${ }^{1}$ In general, fiscal adjustment following a recession should coincide with the beginning economic expansion to avoid contractionary first-round effects, and be coordinated with other macroeconomic policies. Frontloading adjustment increases credibility and reduces overall fiscal costs. The magnitude of the required adjustment is typically linked to the amount necessary to achieve a fiscally sustainable position.

\section{Empirical analysis suggests that the success of fiscal adjustment relates to its} composition, initial conditions, and institutional factors. Econometric evidence from OECD countries ${ }^{2}$ shows that although changes in revenue and expenditure contribute to closing the fiscal gap, expenditure restraint brings about longer lasting and larger adjustment episodes, which are more successful in achieving a debtstabilizing fiscal position. Expenditure reduction demonstrates a firmer commitment to feasible and substantial consolidation, and may trigger lower interest rates and boost private demand. Large initial imbalances and high interest rates are also associated with sizeable adjustments. Finally, fiscal rules have been shown to contribute to successful adjustments, and elections tend to increase the likelihood of entering a consolidation episode.

Selected Episodes of Large Fiscal Adjustments

\begin{tabular}{lrrrr}
\hline & Years & Adjustment 1/ & \multicolumn{2}{c}{ Composition 2/ } \\
\cline { 4 - 5 } & & & Expenditure & Revenue \\
\cline { 2 - 5 } & & & -5.5 & 0.7 \\
Canada & $1993-97$ & 6.8 & -6.1 & 4.6 \\
Denmark & $1983-86$ & 15.5 & -10.8 & 3.4 \\
Sweden & $1994-98$ & 15.9 & -5.4 & 1.4 \\
United Kingdom & $1994-98$ & 10.9 & -2.9 & 2.0 \\
United States & $1993-98$ & 6.5 & & \\
\hline
\end{tabular}

Source: IMF (2006b) and IMF staff estimates.

$1 /$ Change in the central government primary balance during adjustment episode.

2/ Change in expenditure and revenue-to-GDP ratios during adjustment episode.

\footnotetext{
${ }^{1}$ IMF (2006a) "Fiscal Adjustment for Stability and Growth", IMF Pamphlet Series No. 55; IMF (2006b) "Experience with Large Fiscal Adjustments", Occasional Paper Nr. 246;

${ }^{2}$ Guichard, Stephanie et al. (2007), "What Promotes Fiscal Consolidation”, OECD Economics Department Working Papers No. 553; and Alesina, and Perotti (1996) "Fiscal Adjustment in OECD Countries: Composition and Macroeconomic Effects”, NBER Working Paper No. 5730.
} 
Table 1: United Kingdom: Selected Economic and Social Indicators

\begin{tabular}{|c|c|c|c|c|c|c|c|c|}
\hline & 2003 & 2004 & 2005 & 2006 & 2007 & $\begin{array}{r}2008 \\
\text { Est. }\end{array}$ & 2009 & 2010 \\
\hline \multicolumn{9}{|l|}{ Real Economy (change in percent) } \\
\hline Real GDP & 2.8 & 3.0 & 2.2 & 2.9 & 2.6 & 0.7 & -4.2 & 0.2 \\
\hline Domestic demand & 2.8 & 3.4 & 2.1 & 2.4 & 3.0 & 0.5 & -5.0 & -0.3 \\
\hline $\mathrm{CPI}$ & 1.4 & 1.3 & 2.1 & 2.3 & 2.3 & 3.6 & 1.7 & 1.3 \\
\hline Unemployment rate (in percent) $1 /$ & 5.0 & 4.8 & 4.8 & 5.4 & 5.4 & 5.5 & 7.6 & 9.2 \\
\hline Gross national saving (percent of GDP) & 15.1 & 15.0 & 14.5 & 14.2 & 15.6 & 15.3 & 11.8 & 12.4 \\
\hline Gross domestic investment (percent of GDP) & 16.7 & 17.1 & 17.1 & 17.5 & 18.3 & 17.0 & 14.1 & 14.4 \\
\hline \multicolumn{9}{|l|}{ Public Finance (fiscal year, percent of GDP) $2 /$} \\
\hline General government balance & -3.2 & -3.4 & -3.0 & -2.6 & -2.7 & -7.0 & -13.1 & -13.3 \\
\hline Public sector balance & -2.9 & -3.3 & -3.0 & -2.3 & -2.4 & -6.1 & -12.8 & -13.1 \\
\hline Cyclically adjusted balance (staff estimates) & -2.8 & -3.3 & -2.8 & -2.2 & -2.8 & -5.5 & -9.9 & -9.5 \\
\hline Public sector net debt & 32.3 & 34.1 & 35.6 & 36.2 & 36.5 & 42.1 & 56.4 & 67.9 \\
\hline FX-denominated public debt (percent of gross debt) & 0.4 & 0.39 & 0.3 & 0.3 & 0.3 & 0.2 & 0.2 & $\ldots$ \\
\hline \multicolumn{9}{|l|}{ Money and Credit (end-period, 12-month percent change) $3 /$} \\
\hline M4 & 7.3 & 8.9 & 12.8 & 12.5 & 12.3 & 16.4 & 17.4 & $\ldots$ \\
\hline M4 excluding holdings of other financial corporations (OFCs) & 8.5 & 8.1 & 8.6 & 8.9 & 8.9 & 3.1 & 2.4 & \\
\hline M4 lending excluding OFCs (adjusted for effects of securitization) & 12.1 & 11.2 & 11.9 & 12.5 & 10.8 & 4.9 & 2.6 & \\
\hline Consumer Credit 4/ & 11.4 & 11.9 & 9.6 & 7.4 & 7.0 & 4.5 & 2.1 & $\ldots$ \\
\hline \multicolumn{9}{|l|}{ Interest rates (percent; year average) $3 /$} \\
\hline Three-month interbank rate & 3.7 & 4.6 & 4.7 & 5.3 & 6.0 & 5.5 & 1.9 & $\ldots$ \\
\hline Ten-year government bond yield & 4.5 & 4.9 & 4.4 & 4.5 & 5.0 & 4.6 & 3.5 & $\ldots$ \\
\hline \multicolumn{9}{|l|}{ Balance of Payments (percent of GDP) } \\
\hline Current account balance & -1.6 & -2.1 & -2.6 & -3.3 & -2.7 & -1.7 & -2.2 & -2.0 \\
\hline Trade balance & -2.3 & -2.7 & -3.4 & -3.1 & -3.2 & -2.7 & -2.3 & -2.0 \\
\hline Net exports of oil & 0.3 & 0.1 & -0.2 & -0.2 & -0.3 & -0.4 & -0.2 & -0.3 \\
\hline Exports of goods and services (volume change in percent) & 1.8 & 5.0 & 7.9 & 11.3 & -2.8 & 0.8 & -12.9 & 0.7 \\
\hline Imports of goods and services (volume change in percent) & 2.2 & 6.9 & 7.1 & 8.8 & -0.7 & -0.6 & -14.2 & -1.0 \\
\hline Terms of trade (percent change) & 1.3 & 0.2 & -2.6 & -0.6 & 1.1 & 1.3 & -1.1 & -0.6 \\
\hline FDI net & -2.1 & -1.7 & 4.3 & 3.0 & -2.7 & -1.4 & $\ldots$ & $\ldots$ \\
\hline Reserves (end of period, in billion of US dollars) & 46.1 & 49.4 & 46.2 & 51.8 & 57.2 & 53.9 & $\ldots$ & $\ldots$ \\
\hline \multicolumn{9}{|l|}{ Fund Position (as of April 30, 2009) } \\
\hline Holdings of currency (in percent of quota) & & & & & & & & 93.75 \\
\hline Holdings of SDRs (in percent of allocation) & & & & & & & & 15.07 \\
\hline Quota (in millions of SDRs) & & & & & & & & 10,739 \\
\hline \multicolumn{9}{|l|}{ Exchange Rates } \\
\hline Exchange rate regime & & & & & & & & Floating \\
\hline Bilateral rate (May 26,2009 ) & & & & & & & & $£ 0.6272$ \\
\hline Nominal effective rate $(2005=100) 3 / 5 /$ & 96.5 & 101.2 & 100.0 & 100.8 & 103.1 & 90.9 & 78.4 & $\ldots$ \\
\hline Real effective rate $(2005=100) 3 / 5 / 6 /$ & 96.1 & 101.8 & 101.4 & 103.2 & 108.0 & 95.0 & 80.5 & $\cdots$ \\
\hline
\end{tabular}

Sources: National Statistics; HM Treasury; Bank of England; IFS; INS; World Development Indicators; and IMF staff estimates and projections.

1/ ILO unemployment; based on Labor Force Survey data.

2/ The fiscal year begins in April. Debt stock data refers to the end of the fiscal year using centered-GDP as a denominator.

3/ 2009: actual data as of April.

4/ 2009: actual data as of March.

5/ Average. An increase denotes an appreciation.

6/ Based on consumer price data. 
Table 2. United Kingdom: Public Sector Operations Percent of GDP

\begin{tabular}{|c|c|c|c|c|c|c|c|}
\hline & $2007 / 08$ & $2008 / 09$ & $2009 / 10$ & $2010 / 11$ & $2011 / 12$ & $2012 / 13$ & $2013 / 14$ \\
\hline & & \multicolumn{6}{|c|}{ Budget 2009} \\
\hline Total revenue & 38.7 & 38.9 & 35.2 & 36.3 & 37.4 & 37.8 & 38.0 \\
\hline Current revenue & 38.6 & 36.9 & 35.1 & 36.2 & 37.3 & 37.7 & 37.9 \\
\hline Primary revenue & 38.0 & 36.4 & 34.7 & 35.7 & 36.7 & 37.1 & 37.3 \\
\hline Tax revenue & 36.3 & 34.7 & 32.9 & 33.7 & 34.7 & 35.1 & 35.2 \\
\hline Non-tax revenue & 1.7 & 1.7 & 1.8 & 2.0 & 2.0 & 2.0 & 2.0 \\
\hline Interest revenue & 0.6 & 0.5 & 0.4 & 0.4 & 0.6 & 0.6 & 0.7 \\
\hline Capital revenue & 0.1 & 2.0 & 0.1 & 0.1 & 0.1 & 0.1 & 0.1 \\
\hline Total expenditure & 41.1 & 45.1 & 47.6 & 48.2 & 46.4 & 45.0 & 43.5 \\
\hline Current expenditure & 37.7 & 39.2 & 43.1 & 44.2 & 43.0 & 41.9 & 40.8 \\
\hline Primary expenditure & 35.5 & 37.0 & 41.1 & 41.2 & $\ldots$ & $\ldots$ & $\ldots$ \\
\hline Interest payments & 2.2 & 2.2 & 2.0 & 3.0 & $\ldots$ & $\ldots$ & $\ldots$ \\
\hline Capital expenditure & 3.4 & 5.9 & 4.6 & 4.0 & 3.4 & 3.1 & 2.7 \\
\hline Depreciation & 1.3 & 1.3 & 1.4 & 1.4 & 1.4 & 1.4 & 1.4 \\
\hline Current balance $1 /$ & -0.4 & -3.6 & -9.3 & -9.5 & -7.2 & -5.6 & -4.3 \\
\hline Overall balance & -2.4 & -6.3 & -12.4 & -11.9 & -9.1 & -7.2 & -5.5 \\
\hline \multicolumn{8}{|l|}{ Cyclically adjusted } \\
\hline Current balance $1 /$ & -0.7 & -3.1 & -6.6 & -6.4 & -4.8 & -3.9 & -3.2 \\
\hline Overall balance & -2.7 & -5.7 & -9.8 & -9.0 & -6.8 & -5.5 & -4.5 \\
\hline \multicolumn{8}{|l|}{ Memorandum items (Budget 2009) } \\
\hline Output gap & 0.6 & -1.3 & -4.8 & -4.0 & -3.0 & -2.1 & -1.2 \\
\hline Deflator growth & 2.8 & 2.5 & 1.0 & 1.5 & 2.5 & 2.8 & 2.8 \\
\hline Real GDP growth & 3.0 & -1.0 & -2.8 & 1.8 & 3.3 & 3.3 & 3.3 \\
\hline Public sector net debt (excl. FS interventions) $2 /$ & 36.5 & 43.0 & 55.4 & 65.0 & 70.9 & 74.5 & 76.2 \\
\hline Public sector net debt (incl. provision for losses from FS interventions) 3/ & 36.5 & 46.5 & 59.0 & 68.4 & 74.0 & 77.5 & 79.0 \\
\hline General government gross debt 4 / & 43.2 & 55.4 & 71.9 & 82.1 & 87.2 & 89.9 & 90.7 \\
\hline & \multicolumn{7}{|c|}{ Staff projections $5 /$} \\
\hline Total revenue & 38.8 & 39.0 & 35.2 & 36.1 & 37.2 & 37.8 & 38.0 \\
\hline Current revenue & 38.7 & 37.1 & 35.1 & 36.0 & 37.1 & 37.7 & 37.9 \\
\hline Primary revenue & 38.1 & 36.6 & 34.7 & 35.6 & 36.5 & 37.0 & 37.2 \\
\hline Tax revenue & 36.1 & 34.7 & 32.8 & 33.5 & 34.4 & 35.0 & 35.1 \\
\hline Non-tax revenue & 2.0 & 1.9 & 1.8 & 2.1 & 2.1 & 2.0 & 2.1 \\
\hline Interest revenue & 0.6 & 0.4 & 0.4 & 0.4 & 0.6 & 0.6 & 0.7 \\
\hline Capital revenue & 0.1 & 1.9 & 0.1 & 0.1 & 0.1 & 0.1 & 0.1 \\
\hline Total expenditure & 41.2 & 45.1 & 48.0 & 49.2 & 47.7 & 46.4 & 45.1 \\
\hline Current expenditure & 37.8 & 39.4 & 43.4 & 45.1 & 44.2 & 43.2 & 42.2 \\
\hline Primary expenditure & 35.6 & 37.2 & 41.4 & 42.2 & 41.0 & 39.9 & 38.7 \\
\hline Interest payments & 2.2 & 2.2 & 2.0 & 2.9 & 3.2 & 3.3 & 3.5 \\
\hline Capital expenditure & 3.4 & 5.7 & 4.6 & 4.1 & 3.5 & 3.2 & 2.8 \\
\hline Depreciation & 1.3 & 1.3 & 1.4 & 1.4 & 1.4 & 1.4 & 1.4 \\
\hline Current balance $1 /$ & -0.4 & -3.6 & -9.7 & -10.5 & -8.5 & -6.9 & -5.7 \\
\hline Overall balance & -2.4 & -6.1 & -12.8 & -13.1 & -10.4 & -8.6 & -7.0 \\
\hline \multicolumn{8}{|l|}{ Cyclically adjusted } \\
\hline Current balance $1 /$ & -0.7 & -3.0 & -6.8 & -6.9 & -5.6 & -5.1 & -4.6 \\
\hline Overall balance & -2.8 & -5.5 & -9.9 & -9.5 & -7.6 & -6.7 & -6.0 \\
\hline \multicolumn{8}{|l|}{ Memorandum items (staff) } \\
\hline Output gap & 0.6 & -1.5 & -5.2 & -5.1 & -3.7 & -2.3 & -1.2 \\
\hline Deflator growth & 2.8 & 2.2 & 1.0 & 1.5 & 2.7 & 2.8 & 2.8 \\
\hline Real GDP growth & 2.6 & -1.1 & -3.0 & 0.5 & 2.6 & 2.9 & 2.8 \\
\hline Public sector net debt (excl FS interventions) 2/ & 36.5 & 42.1 & 56.4 & 67.9 & 75.2 & 79.9 & 82.6 \\
\hline General government gross debt & 43.2 & 55.4 & 72.7 & 85.0 & 91.9 & 96.1 & 98.6 \\
\hline Net debt contribution of Lloyds/RBS /6 & & 87.3 & & & & & \\
\hline Treasury bills lent to BoE for SLS & & 13.1 & & & & & \\
\hline
\end{tabular}

Sources: Office for National Statistics (ONS), HM Treasury, and staff estimates.

$1 /$ Including depreciation.

2/ End of fiscal year using centered-GDP as the denominator.

3/ Using upper bound of Budget 2009 estimate of net costs of financial sector interventions of 3.5 percent of GDP.

4/ From 2009/10 onwards Budget projections for general government gross debt on Maastricht basis.

5/ Staff projections based on Budget 2009 expenditure plans and using staff's growth assumptions for revenue projections and cyclical adjustment.

$6 /$ Mid point of ONS's estimated range. 
Table 3. United Kingdom: Balance of Payments

\begin{tabular}{|c|c|c|c|c|c|c|c|c|c|c|c|c|c|}
\hline & 2002 & 2003 & 2004 & 2005 & 2006 & 2007 & 2008 & $\begin{array}{l}2009 \\
\text { Proj. }\end{array}$ & $\begin{array}{l}2010 \\
\text { Proj. }\end{array}$ & $\begin{array}{l}2011 \\
\text { Proj. }\end{array}$ & $\begin{array}{r}2012 \\
\text { Proj. }\end{array}$ & $\begin{array}{c}2013 \\
\text { Proj. }\end{array}$ & $\begin{array}{l}2014 \\
\text { Proj. }\end{array}$ \\
\hline & \multicolumn{13}{|c|}{ (In percent of GDP) } \\
\hline Current account & -1.7 & -1.6 & -2.1 & -2.6 & -3.3 & -2.7 & -1.7 & -2.2 & -2.0 & -2.0 & -2.2 & -2.1 & -2.0 \\
\hline Trade balance & -2.6 & -2.3 & -2.7 & -3.4 & -3.1 & -3.2 & -2.7 & -2.3 & -2.0 & -2.1 & -2.3 & -2.3 & -2.2 \\
\hline Trade in goods & -4.4 & -4.3 & -5.1 & -5.5 & -5.8 & -6.4 & -6.4 & -5.6 & -5.3 & -5.5 & -5.7 & -5.6 & -5.6 \\
\hline Exports & 17.3 & 16.5 & 15.9 & 16.9 & 18.4 & 15.8 & 17.4 & 15.5 & 16.0 & 16.2 & 16.4 & 16.5 & 16.5 \\
\hline Imports & 21.8 & 20.8 & 20.9 & 22.3 & 24.1 & 22.2 & 23.8 & 21.1 & 21.4 & 21.7 & 22.1 & 22.1 & 22.0 \\
\hline Trade in services & 1.8 & 2.0 & 2.4 & 2.1 & 2.6 & 3.2 & 3.8 & 3.3 & 3.3 & 3.4 & 3.3 & 3.4 & 3.3 \\
\hline Exports & 8.7 & 9.0 & 9.4 & 9.5 & 10.1 & 10.8 & 11.8 & 11.2 & 11.2 & 11.3 & 11.4 & 11.4 & 11.3 \\
\hline Imports & 6.9 & 7.0 & 7.0 & 7.5 & 7.5 & 7.6 & 8.0 & 7.9 & 7.8 & 7.9 & 8.0 & 8.0 & 8.0 \\
\hline Income balance & 1.7 & 1.5 & 1.5 & 1.7 & 0.7 & 1.5 & 1.9 & 1.1 & 1.1 & 1.1 & 1.2 & 1.3 & 1.3 \\
\hline Current transfers & -0.8 & -0.9 & -0.9 & -0.9 & -0.9 & -1.0 & -0.9 & -1.1 & -1.1 & -1.1 & -1.1 & -1.1 & -1.1 \\
\hline Capital and financial account & 2.3 & 2.1 & 2.6 & 2.4 & 3.0 & 2.4 & 1.5 & $\ldots$ & $\ldots$ & $\ldots$ & $\ldots$ & $\ldots$ & $\ldots$ \\
\hline \multicolumn{14}{|l|}{ Of which: } \\
\hline Direct investment & -1.7 & -2.1 & -1.7 & 4.3 & 3.0 & -2.7 & -1.4 & $\ldots$ & $\ldots$ & $\ldots$ & $\ldots$ & $\ldots$ & $\ldots$ \\
\hline Portfolio investment & 4.5 & 6.1 & -3.6 & -1.7 & 1.1 & 8.0 & 25.5 & $\ldots$ & $\ldots$ & $\ldots$ & $\ldots$ & $\ldots$ & $\ldots$ \\
\hline Other investment & -0.6 & -2.1 & 7.8 & -0.2 & -1.3 & -2.9 & -23.0 & $\ldots$ & $\ldots$ & $\ldots$ & $\ldots$ & $\ldots$ & $\ldots$ \\
\hline
\end{tabular}

Sources: Office of National Statistics (ONS) and staff projections.

Table 4. United Kingdom: Net Investment Position 1/

(Percent of GDP)

\begin{tabular}{|c|c|c|c|c|c|c|c|c|c|}
\hline & 2000 & 2001 & 2002 & 2003 & 2004 & 2005 & 2006 & 2007 & 2008 \\
\hline Assets & 300 & 304 & 284 & 304 & 325 & 383 & 393 & 456 & 493 \\
\hline Direct investment abroad & 63 & 60 & 59 & 61 & 56 & 56 & 56 & 65 & 74 \\
\hline Portfolio investment abroad & 93 & 92 & 78 & 82 & 91 & 109 & 115 & 121 & 122 \\
\hline Other investment abroad & 141 & 149 & 144 & 159 & 176 & 216 & 220 & 268 & 295 \\
\hline Reserve assets & 3 & 3 & 2 & 2 & 2 & 2 & 2 & 2 & 3 \\
\hline Liabilities & 310 & 317 & 295 & 314 & 343 & 403 & 420 & 477 & 487 \\
\hline Direct investment in the UK & 32 & 36 & 32 & 31 & 32 & 39 & 44 & 45 & 47 \\
\hline Portfolio investment in the UK & 109 & 99 & 86 & 95 & 102 & 117 & 128 & 137 & 134 \\
\hline Other investment in the UK & 169 & 182 & 177 & 188 & 210 & 247 & 248 & 294 & 306 \\
\hline Net investment position & -10 & -13 & -11 & -10 & -18 & -20 & -27 & -20 & 6 \\
\hline Direct investment & 32 & 25 & 28 & 29 & 25 & 17 & 12 & 20 & 28 \\
\hline Portfolio investment & -17 & -7 & -8 & -13 & -11 & -8 & -13 & -16 & -13 \\
\hline Other investment & -28 & -33 & -34 & -29 & -33 & -31 & -28 & -26 & -11 \\
\hline Reserve assets & 3 & 3 & 2 & 2 & 2 & 2 & 2 & 2 & 3 \\
\hline Monetary Financial Institutions & -7 & -9 & -13 & -14 & -16 & -12 & -10 & -16 & -17 \\
\hline Other Sectors & -1 & -2 & 3 & 6 & 2 & -2 & -9 & 5 & 37 \\
\hline Public Sector & -3 & -3 & -2 & -3 & -5 & -6 & -8 & -9 & -13 \\
\hline \multicolumn{10}{|l|}{ Memorandum Items: } \\
\hline Change in the net investment position & & -3.5 & 2.2 & 0.9 & -8.1 & -1.8 & -6.5 & 6.4 & 26.6 \\
\hline o/w Valuation change & & -0.9 & 4.5 & 2.9 & -5.6 & 0.5 & -3.6 & 8.7 & 27.9 \\
\hline Current account balance & & -2.1 & -1.8 & -1.6 & -2.1 & -2.6 & -3.3 & -2.7 & -1.7 \\
\hline
\end{tabular}

Source: Office on National Statistics.

1/ Data correspond to the end of the indicated period. They are expressed as a percent of the cumulated GDP of the four preceding quarters. 
Table 5. United Kingdom: Medium-Term Scenario (Percentage change, unless otherwise indicated)

\begin{tabular}{|c|c|c|c|c|c|c|c|c|c|c|c|}
\hline & 2004 & 2005 & 2006 & 2007 & 2008 & $\begin{array}{c}2009 \\
\text { Proj. }\end{array}$ & $\begin{array}{l}2010 \\
\text { Proj. }\end{array}$ & $\begin{array}{c}2011 \\
\text { Proj. }\end{array}$ & $\begin{array}{c}2012 \\
\text { Proj. }\end{array}$ & $\begin{array}{c}2013 \\
\text { Proj. }\end{array}$ & $\begin{array}{c}2014 \\
\text { Proj. }\end{array}$ \\
\hline Real GDP & 3.0 & 2.2 & 2.9 & 2.6 & 0.7 & -4.2 & 0.2 & 2.1 & 2.9 & 2.8 & 2.8 \\
\hline Q4/Q4 1/ & 2.4 & 2.4 & 2.8 & 2.4 & -1.8 & -2.5 & 0.5 & 2.9 & 3.1 & 2.7 & 2.7 \\
\hline Real domestic demand & 3.4 & 2.1 & 2.4 & 3.0 & 0.5 & -5.0 & -0.3 & 2.0 & 3.2 & 2.8 & 2.7 \\
\hline Private consumption & 3.1 & 2.2 & 1.5 & 2.1 & 1.2 & -3.2 & -1.1 & 2.6 & 3.3 & 2.9 & 2.9 \\
\hline Government consumption & 3.0 & 2.0 & 1.6 & 1.2 & 2.8 & 3.5 & 1.3 & -1.3 & 0.3 & 1.2 & 1.2 \\
\hline Fixed investment & 4.8 & 2.4 & 6.5 & 7.8 & -2.8 & -14.9 & -4.0 & 3.8 & 6.3 & 4.5 & 4.1 \\
\hline Public 2/ & 2.3 & 11.5 & 6.5 & 6.0 & 26.8 & 2.9 & 3.0 & -16.6 & 3.0 & 2.2 & 2.1 \\
\hline Residential & 9.6 & 0.7 & 8.4 & 3.4 & -11.9 & -28.6 & -7.5 & 4.2 & 4.6 & 2.8 & 2.8 \\
\hline Business 2/ & 0.8 & 4.9 & 4.6 & 11.9 & 1.7 & -13.9 & -5.0 & 9.4 & 7.3 & 5.3 & 4.8 \\
\hline Stocks 3/ & 0.1 & 0.0 & 0.0 & 0.1 & -0.4 & -1.1 & 0.8 & 0.2 & 0.1 & 0.0 & 0.0 \\
\hline External balance 3/ & -0.7 & 0.0 & 0.4 & -0.6 & 0.4 & 0.8 & 0.4 & 0.0 & -0.3 & -0.1 & 0.0 \\
\hline Exports of Goods and Services & 5.0 & 7.9 & 11.3 & -2.8 & 0.8 & -12.9 & 0.7 & 5.0 & 4.9 & 4.6 & 4.5 \\
\hline Imports of Goods and Services & 6.9 & 7.1 & 8.8 & -0.7 & -0.6 & -14.2 & -1.0 & 4.5 & 5.8 & 4.5 & 4.2 \\
\hline Exports of Goods and Services (ex. fraud) 4/ & 5.8 & 5.4 & 9.1 & 1.7 & 1.6 & -12.1 & 0.7 & 5.0 & 4.9 & 4.6 & 4.5 \\
\hline Imports of Goods and Services (ex. fraud) 4/ & 7.7 & 4.9 & 6.8 & 3.4 & 0.1 & -13.5 & -1.0 & 4.5 & 5.8 & 4.5 & 4.2 \\
\hline Current account $5 /$ & -2.1 & -2.6 & -3.3 & -2.7 & -1.7 & -2.2 & -2.0 & -2.0 & -2.2 & -2.1 & -2.0 \\
\hline CPI Inflation & 1.3 & 2.1 & 2.3 & 2.3 & 3.6 & 1.7 & 1.3 & 1.4 & 1.7 & 2.0 & 2.0 \\
\hline Output gap 6/ & 0.1 & -0.3 & 0.0 & 0.4 & -0.1 & -5.0 & -5.2 & -4.1 & -2.6 & -1.5 & -0.5 \\
\hline \multicolumn{12}{|l|}{ Employment and productivity } \\
\hline Employment & 1.1 & 1.0 & 0.9 & 0.7 & 0.8 & -1.6 & -1.2 & 1.0 & 1.9 & 1.7 & 1.0 \\
\hline Unemployment rate 7/ & 4.8 & 4.8 & 5.4 & 5.4 & 5.5 & 7.6 & 9.2 & 9.0 & 7.7 & 6.5 & 6.1 \\
\hline Productivity $8 /$ & 1.9 & 1.1 & 2.1 & 2.1 & -0.1 & -2.5 & 1.5 & 1.1 & 1.0 & 1.1 & 1.8 \\
\hline
\end{tabular}

Sources: Office for National Statistics; and IMF staff projections.

1/ Percentage change in quarterly real GDP in the fourth quarter on four quarters earlier.

2/ Public investment and business investment in 2005 and 2006 exclude the transfer of nuclear reactors.

3/ Contribution to the growth of GDP.

4/ These numbers exclude VAT-related fraudulent activity.

$5 /$ In percent of GDP.

6/ In percent of potential GDP.

7/ In percent of labor force, period average; based on the Labor Force Survey.

8/ Whole economy, per worker. 
Annex I. Selected Policy Measures in Response to the Crisis since July $2008^{1}$

\section{Liquidity Support}

...to alleviate funding market strains

- Expanded the size and frequency of BoE's long-term repo operations, and the range of eligible collateral to boost banks' access to term funding

- Introduced the Discount Window Facility $(D W F)$ as a permanent liquidity insurance facility for the banking system.

- Extended the drawdown period for the Special Liquidity Scheme (a T bills-illiquid asset swap program), and lengthened the $D W F$ 's maximum maturity to 364 days (in addition to the standard option to draw for 30 days) upon the closure of SLS's drawdown window in January 2009. A total of $£ 185$ billion of T bills were lent through the SLS.

- Established an unlimited US dollar swap line with the Federal Reserve to relieve pressure in the US dollar funding markets. The swap line arrangement is in place until February 2010.

\section{Financial Sector Assistance}

...to boost banks' capital and foster confidence

- Provided up to $£ 78.1$ billion in capital injections in Lloyds/HBOS and RBS (including $£ 22.1$ billion in the banks' payment of shares as fees for asset insurance). The government has taken significant voting stakes in the banks. Lloyds has since repaid $£ 2.3$ billion to the government.

- Set up Asset Protection Scheme to insure banks, for a fee, against excessive losses on troubled assets for at least 5 years. Participating banks will fully absorb the first loss, and the Treasury will absorb 90 percent of any remaining losses. So far, RBS and Lloyds have placed a total of $£ 585$ billion of assets under the scheme. As part of the agreement, the two banks have committed to increasing their lending.

- Clarified FSA's minimum capital ratio benchmark and disclosed key stress test assumptions to increase transparency of FSA's supervisory requirements.

- Enacted temporary short sale ban (in the four months to January 2009) on banking and other financial firm stocks.

...to support credit flows and private-sector assets

\footnotetext{
${ }^{1}$ Prepared by MK Tang.
} 
- Introduced Credit Guarantee Scheme by the Treasury to provide guarantees for unsecured bank debts for up to five years (including rollover), and Asset-Backed Securities Guarantee Scheme to insure investors against credit and extension risks of new issues of AAA-rated UK RMBS.

- Launched program to purchase high-quality private sector assets. Under the Asset Purchase Facility, the BoE may buy up to $£ 50$ billion of private assets, including investment-grade sterling commercial paper and corporate bonds

- Reversed decision to run down Northern Rock's mortgage book in an effort to support mortgage lending. Northern Rock will now increase mortgage lending by up to $£ 14$ billion in 2009 and 2010.

\section{Resolution and Prudential Measures}

...to resolve failing banks

- $\quad$ Resolved Bradford \& Bingley, promptly transferring its branch network and retail deposit book to another bank to ensure undisrupted access by depositors, while the remaining parts of the business were taken into temporary public ownership.

- $\quad$ Expedited a merger between Lloyds and HBOS.

...to fortify the prudential framework

- $\quad$ Raised the ceiling of retail deposit guarantee to $£ 50,000$ from $£ 35,000$. Prefunding the insurance scheme (FSCS) with levies on the industry remains an option.

- Introduced the Special Resolution Regime, a permanent regime to deal with failing banks. The BoE can make independent recommendations to the FSA regarding triggering the resolution regime.

- Introduced a new capital instrument, Profit Participating Deferred Shares (PPDS), to allow building societies to raise core tier 1 capital from external sources.

- Phasing in significant reforms to FSA's regulatory approach, notably strengthening liquidity and capital requirements on banks

- Strengthened through legislation the BoE's role in maintaining financial stability.

\section{Monetary Policy Actions}

...to ease monetary conditions

- $\quad$ Reduced policy rates rapidly to a historical low of 0.5 percent. 
- Flexibly adjusted the operational arrangements of the standing facilities (the width of the interest rate corridor between the facilities and of the target range of reserves balance) to allow more effective implementation of monetary policy objectives.

- Introduced unconventional monetary policy. In March, the BoE began unsterilized purchase of assets ( $£ 125$ billion planned until July). Gilts of 5-25 year maturities constitute a majority of the purchase.

\section{Macroeconomic Stabilization Efforts}

...to lift domestic demand

- Adopted a fiscal stimulus package of about 2 percent of GDP, implemented over 20082010. Key measures included a 13-month VAT reduction (from 17.5 to 15 percent), advancing infrastructure investment, and various tax incentives for businesses. The twin fiscal rules have been suspended and replaced with a more flexible temporary operating rule.

- Introduced subsidies to companies hiring jobless people ("golden hellos"). Subsidies are expected to total about $£ 500$ million.

- $\quad$ Provided a job offer, work-focused training or work experience to every 18-24 year old who has been claiming unemployment benefit for 12 months.

...to provide relief to distressed homeowners

- Encouraged banks to more widely pursue mortgage workouts and avoid repossessions.

- $\quad$ Provided guarantees for deferred mortgage interest payments by distressed borrowers for up to 2 years. Contingent liability associated with the Homeowners Support Mortgage Scheme is estimated at $£ 1$ billion.

- Extended stamp duty holiday for all houses up to $£ 175,000$.

... to provide support for businesses:

- Introduced a trade credit insurance scheme, various credit guarantee schemes (e.g., the Working Capital Scheme), and a $£ 750$ million Strategic Investment Fund to support investment. 


\section{Annex II. Sterling and External Adjustment ${ }^{1}$}

The steep depreciation of sterling in the last two years followed a period of growing external imbalances. In the context of robust capital inflows - including due to central banks' increased accumulation of sterling-denominated assets, strong domestic demand, and declining investment income, the UK's current account deficit had swelled to $3 \frac{1}{2}$ percent of GDP and net liabilities climbed to 30 percent of GDP by mid-2007. Since then, the onset of the global financial crisis and the steady deterioration of UK's economic outlook have provided a backdrop for a very rapid external correction. In REER terms, sterling fell by 27 percent between mid2007 and April 2009—a pace of depreciation that exceeded that following

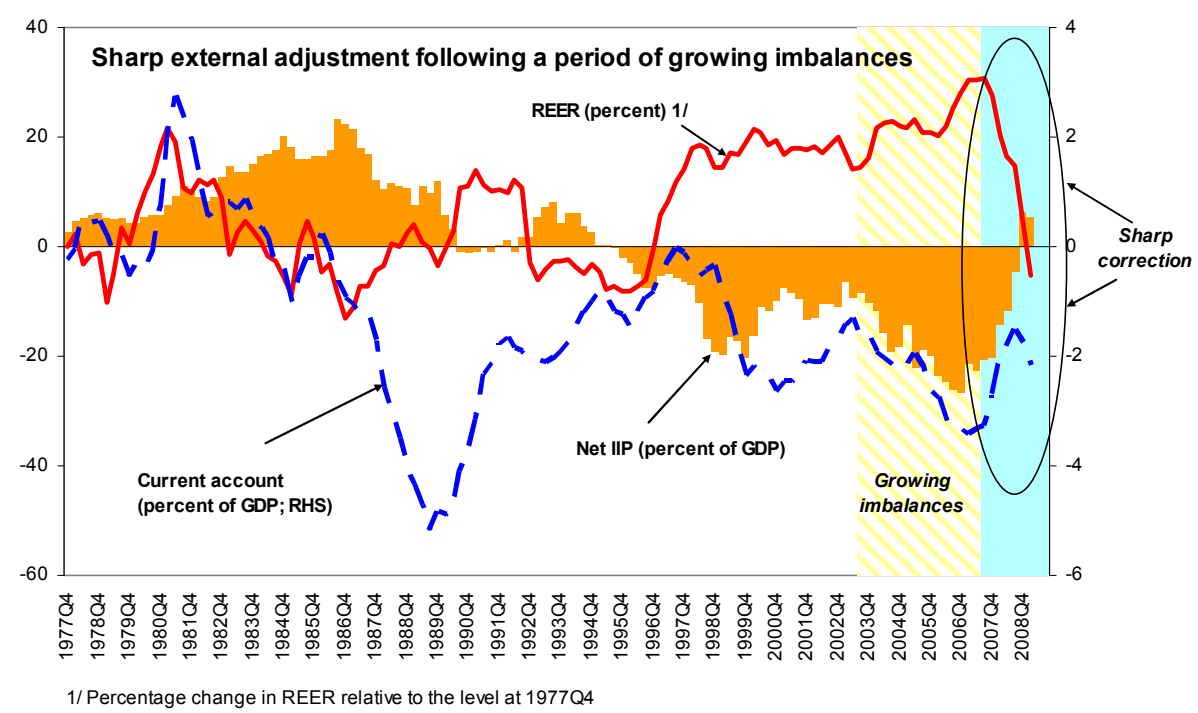
the exit from the European Exchange Rate Mechanism in the early 1990s. In parallel, the UK's net investment position swiftly rose to 6 percent of GDP at end-2008.

The dramatic scale and rapidity of the external adjustment in part reflect the broad shifts in the trend of global capital flows. Increases in market volatility and pressure to deleverage since the outbreak of the crisis have led to a general repricing of currencies of high-external deficit, high-interest rate countries. Furthermore, the retrenchment of cross-

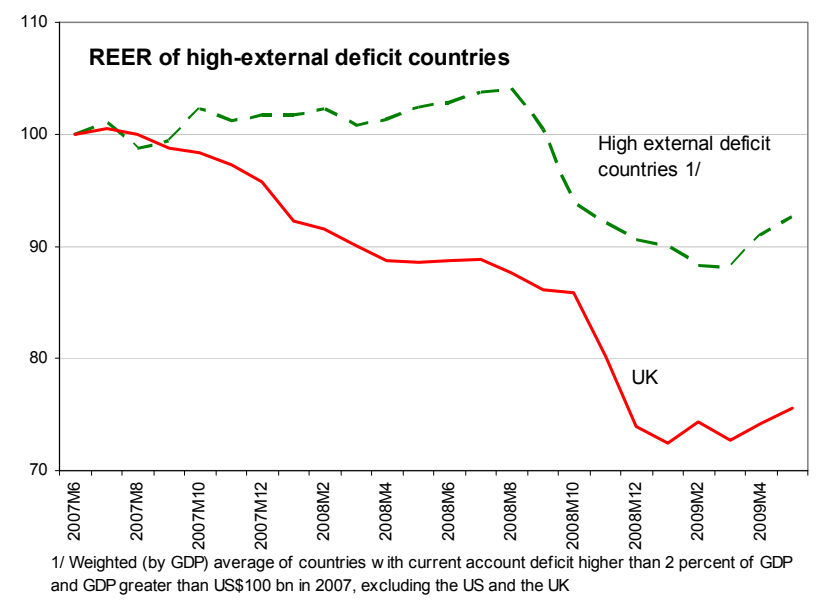

${ }^{1}$ Prepared by MK Tang.

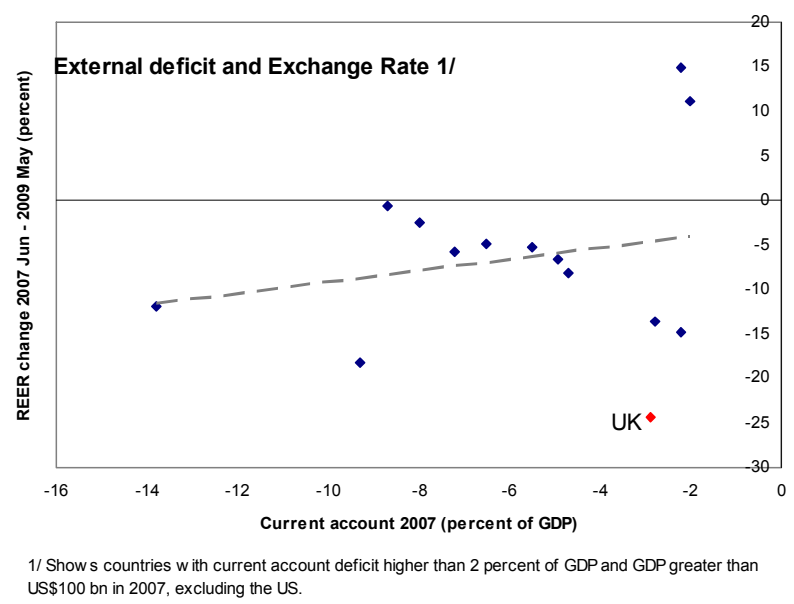

US $\$ 100 \mathrm{bn}$ in 2007 , excluding the US. 
border banking flows amid the financial turmoil has heightened FX funding needs of countries that have large FX banking liabilities. The UK, in particular, experienced massive foreign withdrawals from its banking system in 2008Q4, especially in FX deposits. Although UK banks' own withdrawals from foreign banks and their sales of foreign debt securities matched these foreign withdrawals, the private FX swap market was heavily stressed, which might have

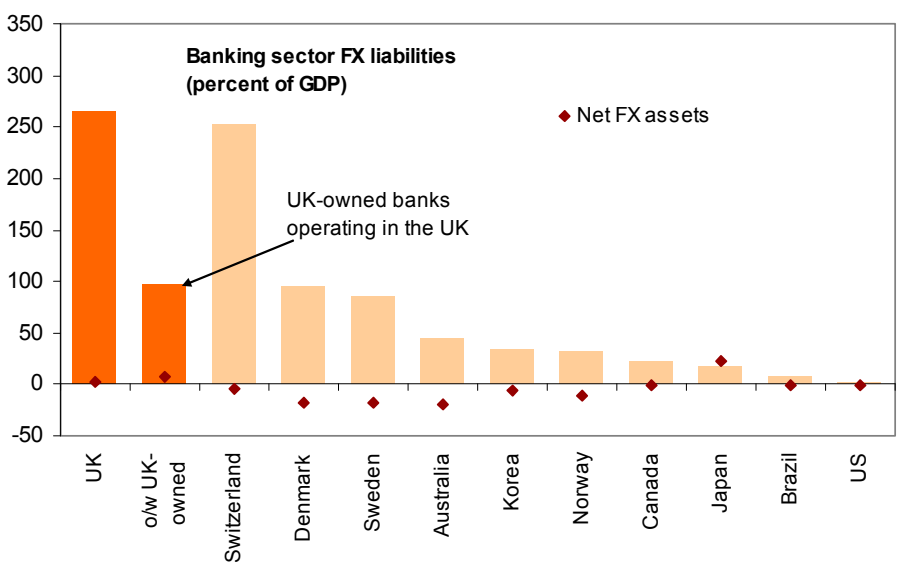
compounded the sell-off pressure on sterling in that quarter. ${ }^{1}$

More generally, the premium required to compensate for the risk of sterling appears to have risen sharply amid heightened global risk aversion, and weighed heavily on the currency. The Bank of England has been engaged in aggressive monetary easing efforts since October 2008. But as the recent issues of the Bank of England's Inflation Report point out, the resulting reduction in interest rate differentials between sterling and other major currencies is unlikely to fully account for the subsequent fall in the currency. Meanwhile, market perceptions of risk of the sterling exchange rate appear to closely track the global investment sentiment. Until the recent improvement in the financial market conditions, the exchange rate risk - as measured by market instruments - had been elevated and significantly tilted to the downside. Such unfavorable risk assessments by the market likely pushed up sterling's risk premium and contributed to the currency's weakness.
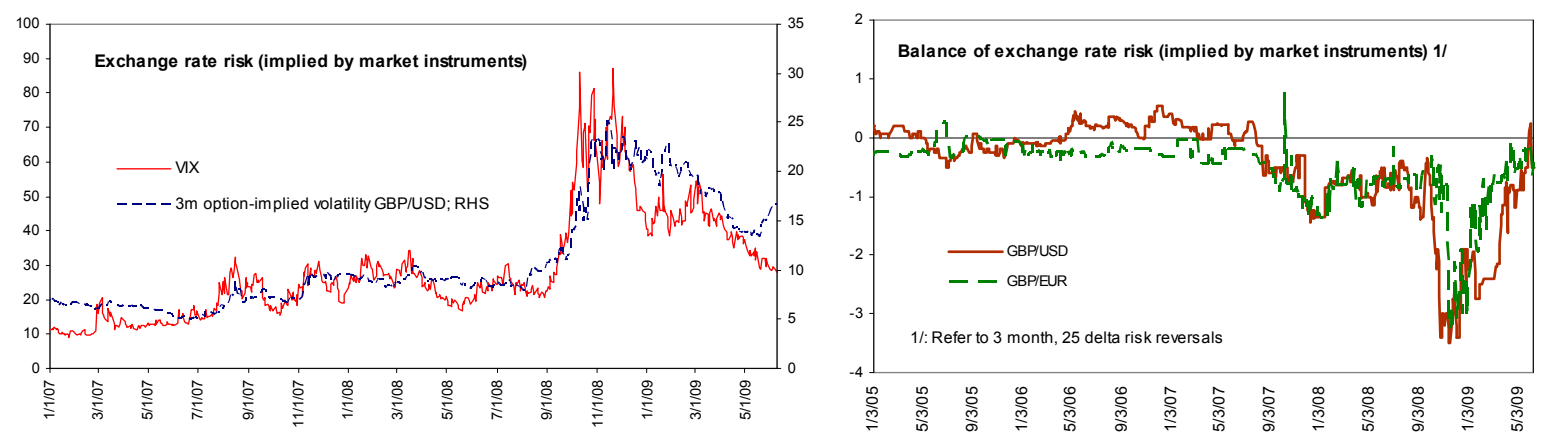

Three elements concerning the composition of the UK balance sheet, in particular, underscore the currency risks.

- $\quad$ First, the UK's external position is highly leveraged (with gross assets and liabilities each at 5 times GDP), and is essentially composed of net risky assets (direct

\footnotetext{
${ }^{1}$ One-year USD/GBP cross-currency basis swap spreads were very volatile and on several occasions surged past 100 basis points.
} 
investment) funded by net debts (debt securities and loans), with the banking sector intermediating most of the cross-border capital flows. Such a financing structure leaves the UK's external position vulnerable to exchange rate fluctuations, and may lead to a deeper feedback loop between banking sector strains and capital inflow retrenchment.

- Second, the public sector is expected to become an increasingly large net debtor, even though the UK's aggregate net liabilities have fallen. The projected sizable rise in government borrowing, the considerable contingent liabilities from the banking sector, and the lack of full clarity about the future fiscal consolidation path pose risks to confidence in the public sector's debt sustainability.

- Third, the UK's substantial exposure to FX liabilities - primarily through its banking sector-implies a non-negligible threat of a destabilizing FX liquidity crunch. The adequacy of the UK banking system's liquid FX assets against short-term FX liabilities appears to crucially hinge on the liquidity and market value of its holding of foreign debt securities. ${ }^{2}$ A renewed deterioration in the global debt securities markets may therefore exacerbate risks of a FX liquidity crunch in the UK. While the existing US dollar swap line with the Federal Reserve mitigates against such risks, its effectiveness in crisis situations remains to be tested. $^{3}$

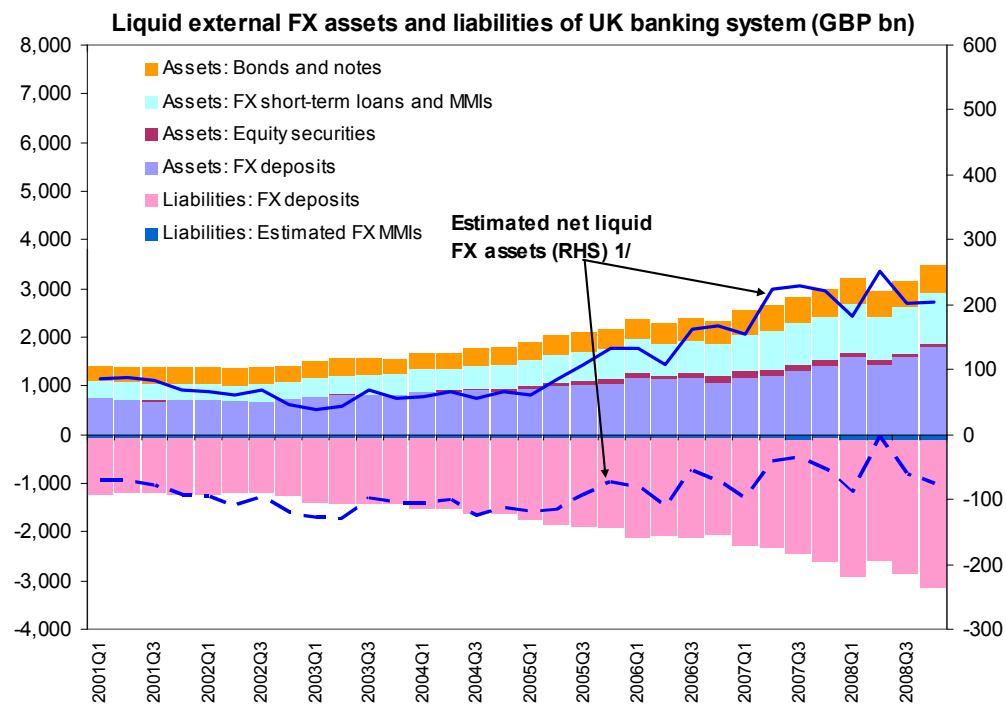

$1 /$ The solid line and the dashed line assume $75 \%$ and $25 \%$ of foreign bonds and notes are liquid, respectively

\footnotetext{
${ }^{2}$ There are two important caveats in interpreting the data. First, the balance of payments data on which the chart is based are not consolidated on the firm-level basis - a large portion of the external FX assets and liabilities shown in the data may represent intra-firm transactions, and the actual inter-firm position may be much smaller. Second, many UK-resident banks may have access to FX liquidity support from foreign central banks through their overseas units.

${ }^{3}$ Notably, official FX liquidity assistance to a bank is contingent upon its ability to produce eligible collaterals, which may become scarce in times of severe banking strains.
} 
The value of sterling appears to be currently broadly in line with the fundamentals. Multilaterally consistent estimates, using the IMF's CGER methodology, indicate that an external current account deficit of $2 \frac{1}{2}$ percent of GDP would be consistent with the UK's structural economic factors. The April 2009 CGER exercise-based on March REERsuggested that sterling was undervalued. But the recent rebound of the currency (by roughly 8 percent in REER terms between March and June) appears to have brought sterling broadly in CGER Estimates 1/

\begin{tabular}{lcc}
\hline & April 2009 & May 2008 \\
\cline { 2 - 3 } Macro Balance & -9 & 6 \\
Equilibrium RER & -14 & 7 \\
External Sustainability & 2 & 11 \\
Overall & $\mathbf{0 - 1 5}$ below & $\mathbf{5 - 1 0}$ above \\
\hline
\end{tabular}

1/ See IMF Occasional Paper No. 261 for details of CGER methodology line with the fundamentals as of mid-June. Consensus forecasts, similarly, predict that the medium-term exchange rate is close to its spot value. ${ }^{4}$

\footnotetext{
${ }^{4}$ Based on June 2009 Foreign Exchange Consensus Forecasts, referring to the USD/GBP exchange rate.
} 


\section{Annex III. Assessing the Impact of the Financial Crisis on Potential Growth ${ }^{1}$}

The deep and protracted financial crisis is likely to reduce the UK economy's potential to grow, in both the near and medium terms. In the near term, key factors that would hamper potential supply include:

- a slower rate of net capital accumulation (including due to more rapid capital scrapping reflecting forced discontinuation of ongoing capital projects);

- a likely decline in migrant worker inflows (in response to the UK's dimmer employment outlook and the dramatic sterling depreciation);

- a possible decrease in the labor participation rate due to dropout of discouraged job seekers, and a rise in the structural unemployment rate caused by shifts in the sectoral composition of the economy;

- $\quad$ increased technological frictions (e.g., less efficient transfers of assets, scarcer financing of R\&D investments) resulting from severe strains in credit flows; and

- a loss of labor skills arising from prolonged unemployment.

Even in the medium term when the cyclical fluctuations in the factor markets have dissipated, the ongoing adjustment in certain sectors - notably the financial sector-are likely to have an enduring impact on economy-wide productivity and potential supply. In a recent paper based on the experiences of OECD countries, for instance, Furceri and Mourougane (2009) find that a severe financial crisis appears to lower potential output by 4 percent on average, with the loss spread over several years. ${ }^{2}$

Although there are multiple methodologies for estimating potential growth, this annex relies on a simple production function approach to focus on structural factors. Specifically, the likely changes in the factor markets due to the current crisis are first evaluated quantitatively. Estimates are then made on the effects of possible financial sector shrinkage on the growth residual - taking into account both the direct impact and the associated spillover implications for the rest of the economy. Finally, these factors are aggregated into a range of probable estimates on the UK's potential growth in the near and medium term.

The main objective of this annex is to present an illustrative quantification of the key factors relevant for potential supply, rather than providing a definitive assessment on the

\footnotetext{
${ }^{1}$ Prepared by MK Tang.

${ }^{2}$ Furceri, D. and A. Mourougane (2009), "The Effect of Financial Crisis on Potential Output: New Empirical Evidence from OECD Countries." OECD Economics Department Working Papers No. 699.
} 
UK's future growth potential. With many determining factors still in flux, the estimates are tentative and subject to substantial uncertainty.

\section{Simple Production Function Approach}

A production function approach provides a structural mapping of the input factors and the growth residual into a potential growth estimate. Before the outbreak of the crisis, historical data suggested that potential growth was about $23 / 4$ percent - with the labor, capital stock, and growth residual components contributing approximately $3 / 4,1 / 2$, and $1 \frac{1}{2}$ percentage points, respectively. ${ }^{3}$

\section{A. Productive capital stock}

Due to both demand uncertainly, credit tightening, and abrupt structural shifts, gross productive investments are expected to fall rapidly and capital scrapping is likely to occur at a faster pace. The rate of net capital stock accumulation is hence likely to slow sharply in the near term. Comparing to the pre-crisis estimate of $2 \frac{1 / 4}{4}$ percent, net growth of capital stock is currently projected to decline to $1 \frac{1 / 4}{4}$ percent in 2008 and to 0 percent in 2010 , before slowly rising to 1 percent in 2014.

\section{B. Labor supply}

Reflecting past sterling depreciation and dimmer employment prospects, the current downward trend of migrant worker inflows is likely to persist in the near term. ${ }^{4}$ The exercise assumes that migrant worker inflows will decline in line with the expected increase in the unemployment rate. The annual net migrant worker inflows would then fall to 0.2 percent of the workforce in 2010 from the pre-crisis estimate of 0.6 percent of the workforce, before rebounding as the unemployment rate recedes. Moreover, a likely decline in the labor participation rate and increase in the structural component of the unemployment rate- due to prolonged unemployment and skill mismatch — would further reduce the labor factor's contributions to potential growth.

\section{Growth residual and financial sector adjustment}

\section{(i) Direct impact of financial sector retrenchment}

The UK's financial sector had been a strong economic driver, making significant contribution to the "growth residual" of the overall economy in recent years. Indeed, the UK ranks near the top among the advanced economies in terms of the pace of growth of the financial sector.

\footnotetext{
${ }^{3}$ A simple Cobb-Douglas model with a labor share of 0.7 and capital share of 0.3 is assumed.

${ }^{4}$ The number of migrant workers from new Eastern European EU member states dropped by 35 percent in the four quarters to Q1 2009, compared to the previous year.
} 
Even with only a modest increase in capital consumption and no rise in the number of workers employed, the sector expanded more than twice as fast as the overall economy from 2000 to 2007, in both nominal and real terms. Possibly reflecting an upgrade in the industry's labor skill requirement, the per-employee compensation in the UK financial sector climbed rapidly, from 140 percent of the national average in 2000 to 180 percent in 2007. Most

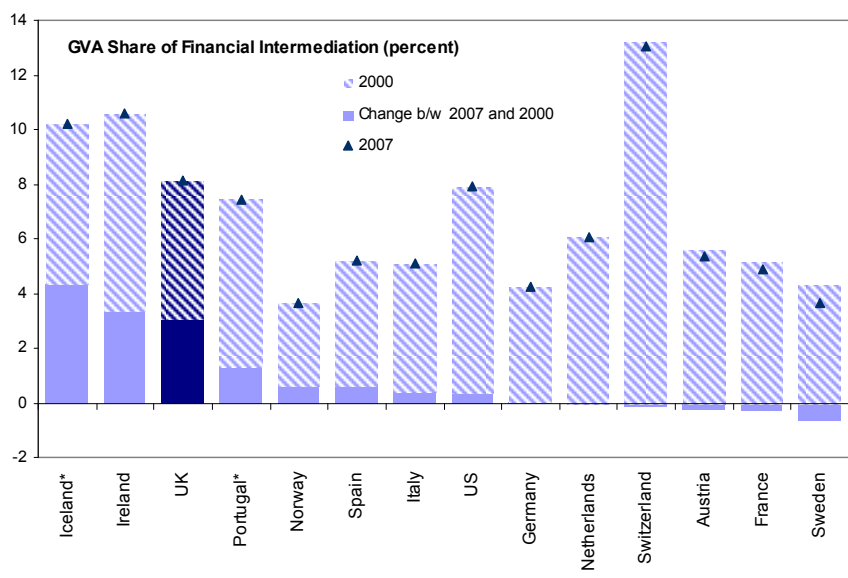

*Iceland: 2000-2005; Portugal: 2000-2006 of the gain by the financial sector, however, has been accounted for by non-labor inputsbetween 2000 and 2007, the sector's gross operating surplus jumped by $2 \frac{1}{2}$ percentage points to $3 \frac{3}{4}$ percent of total gross value added. ${ }^{5}$
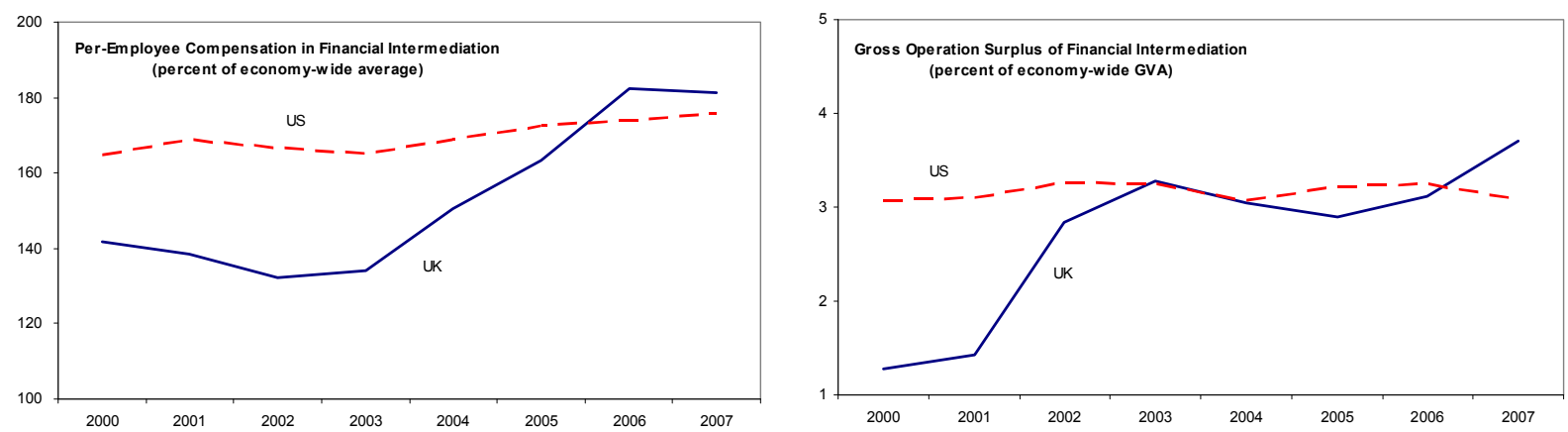

Looking ahead, with the ongoing crisis casting doubt on the sustainability of the existing business models as well as the past gains, the financial sector is likely to go through a protracted adjustment that would impinge on both its importance to the economy and its future growth rates. The associated consequences for the overall potential supply would depend upon, among other factors, the extent to which the financial sector's non-labor inputs can retain their productive value and continue to provide the kind of growth impetus to the overall economy as before, and how completely worker skills can be transferred from the financial sector to other industries. ${ }^{6}$

\footnotetext{
${ }^{5}$ The financial sector's net operating surplus (i.e., after deduction of fixed capital consumption) has risen by a similar amount, from 3/4 percent of total gross value added in 2000 to 31/4 percent in 2007 .

${ }^{6}$ In real terms, on average between 2000 and 2007, the financial sector grew 31/4 percentage points per year faster than the overall economy-with most of the growth differential accounted for by non-labor inputs. Given a weight of about 7 percent of the economy, a drop in growth rates of the financial sector to the economy-wide
} 


\section{(ii) Spillover implications for the rest of the economy}

Explicit consideration of the financial sector's linkage to other industries provides a perspective to assess the potential effects of the sector's adjustment on the rest of the economy. The literature suggests that to the extent that financial development generates positive spillovers to the rest of the economy, the fortune of those industries that are more reliant on external finance would tend to depend more heavily on the strength of the financial sector.

For the UK, the data suggests that this channel of financial spillovers indeed appears to be present. While on the aggregate level there has not been a systematic rise in the output growth of nonfinancial industries (after adjusting for employment) over the past few years, a sectoral decomposition reveals that industries that are more dependent on external finance tend to grow more rapidly as the UK's financial sector expands.

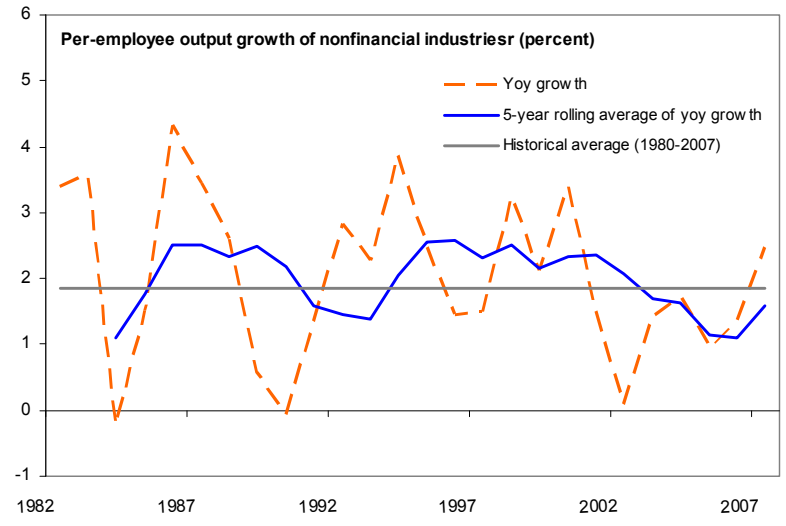

Specifically, a simple exercise is carried out first to categorize the UK's 21 main industries into two groups according to their intrinsic dependence on external finance. Then the two groups' growth performances are assessed in relation to the financial sector's, after adjusting for each industry's unobserved fixed factors. ${ }^{7}$ Results show that growth of the external finance-dependent industries is significantly correlated with the financial sector's growth. ${ }^{8}$ By contrast - in an indication that the finding is unlikely driven by spurious relationshipsno such correlation is found for the UK's less external finance-dependent industries.

average would imply roughly a fall of $1 / 4$ percentage point in the overall economic growth. Potential errors in measuring the past price deflator of financial sector output, however, might bias the result.

${ }^{7}$ The industry-level measure of external finance dependence is taken from De Serres, A., S. Kobayakawa, T. Slok, and L. Vartia (2006) "Regulation of Financial Systems and Economic Growth." OECD Economics Department Working Papers No. 506. They extend the methodology in Rajan, R. and L. Zingales (1998) "Financial Dependence and Growth." American Economic Review vol. 88(3), pp. 559-86 to include services industries and update the measure with more recent date.

${ }^{8}$ In particular, a 1 percentage point increase in financial sector growth appears to raise growth of external finance-dependent industries by 0.6 percentage point on average. 


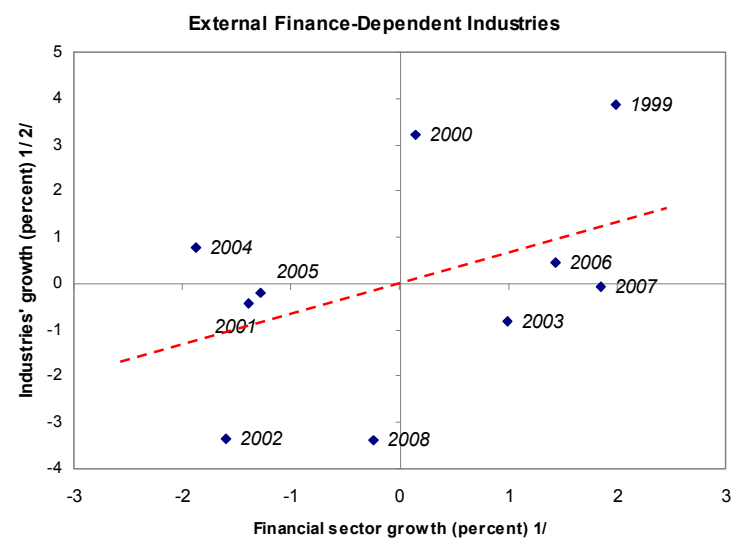

1/ Average annual growth over 1998-2008, after adjusting for industry-fixed effects 2/ Average growth of all external finance-dependent industries

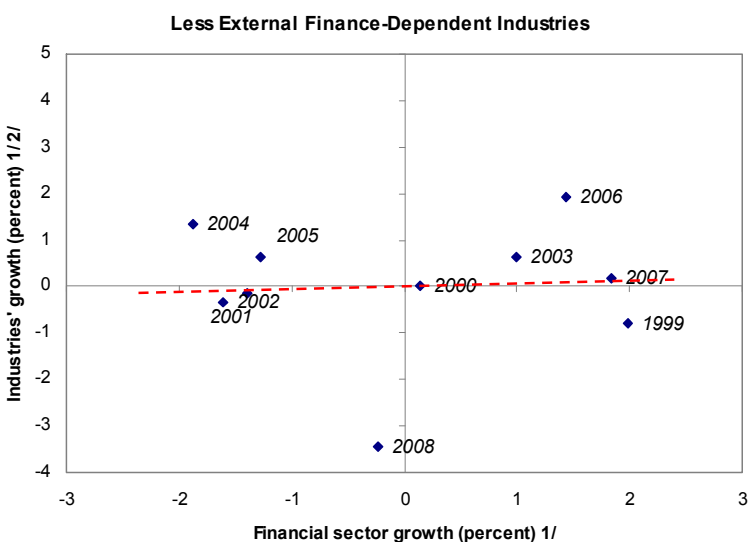

1/ Average annual growth over 1998-2008, after adjusting for industry-fixed effects 2/ Average growth of all less external finance-dependent industries

Based the observed linkage of the financial sector with the external finance-dependent industries, a 1 percentage point reduction in financial sector growth is estimated to translate into approximately a $1 / 4$ percentage point decline in the output growth of the other industries. ${ }^{9}$ Over a long horizon, though, the composition of the economy may shift (in favor of less external-dependent industries) in response to the downsizing of the financial sector, possibly reducing the negative impact of the decreased financial spillovers on the rest of the economy.

\section{Aggregated impacts on potential growth}

Overall, taking together the prospective impact on the capital stock, the labor supply, as well as the direct and indirect effects of financial sector retrenchment on the growth residual, a range of probable scenarios suggest a fall in potential growth to $1 / 4$ to $1 \frac{1}{4}$ percent in the near term, before a subsequent pickup to around $1 \frac{3}{4}$ to $2 \frac{1}{4}$ percent in the medium term.

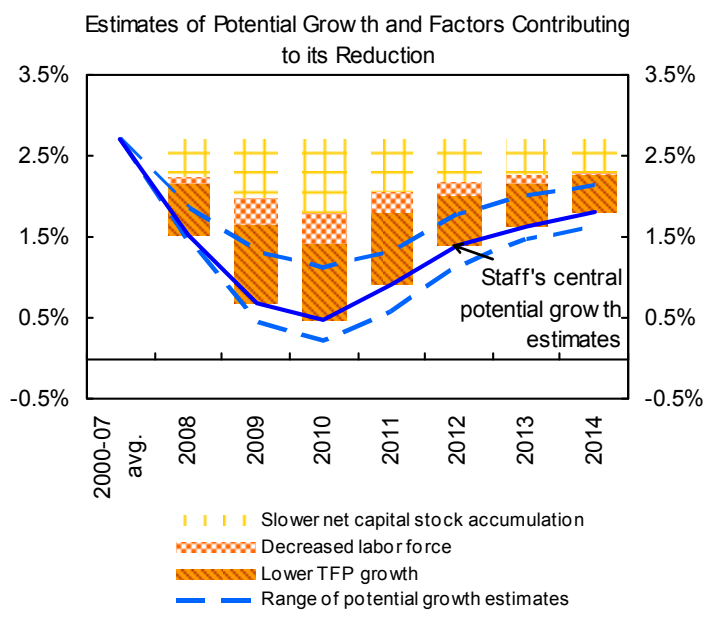

\footnotetext{
${ }^{9}$ While no explicit attempts are made to separate the effect on the growth residual from that on the factor inputs of the nonfinancial sectors, the latter effect is likely small at the (annual) frequency on which the result is based.
} 


\section{Uncertainty around the estimates}

The assumed economic relationships could be mis-specified. Generally, parameters underlying potential growth estimation are derived from historical observations. In times of significant regime change - as in the current circumstances - there are obvious risks that past observations can no longer provide valid economic inferences .

Uncertainty around the estimates is further amplified by the fact that many key factors affecting potential supply are still very much in flux. For instance, as the crisis is still evolving, the ultimate extent of the economic downturn and the financial sector transformation are not yet clear. Also, as an open economy, the UK's potential supply is strongly influenced by the likely changes in other major economies' own growth potential. Furthermore, there are risks that the fast deteriorating fiscal outlook would adversely affect potential growth through its impact on long-term interest rates, although so far this channel appears muted. 


\section{Annex IV. Central Bank Asset Purchases in a Cross-Country Perspective ${ }^{1}$}

Central bank balance sheets have expanded significantly since the beginning of the financial crisis. At end-May 2009, the total assets of Fed, BoE, and ECB were between 45170 percent above pre-crisis levels, despite some decline from their October 2008 peaks. Balance sheets have grown as central banks have provided unparalleled amounts of liquidity to the financial system, created new funding facilities, and, in some cases, started outright asset purchases. Although some of the extra liquidity has been absorbed through offsetting open market operations, monetary bases have also increased considerably. The Bank of Japan marks the only outlier among the major central banks, having seen only a modest increase in its balance sheet so far.
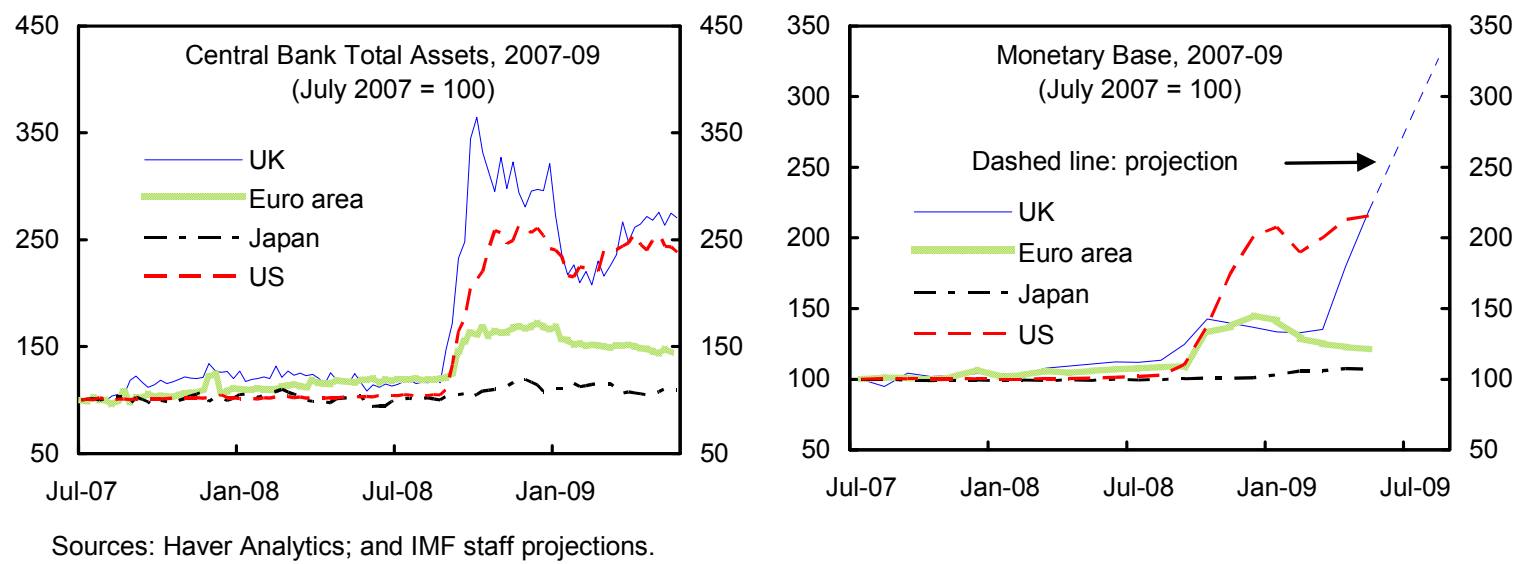

Recently launched asset purchase programs are further boosting balance sheets, most notably at the Fed and BoE. All major central banks have set out programs to purchase selected financial assets, aiming for some combination of improved market liquidity, higher asset prices, increased new issuance, and a greater money supply. The Fed's program is the most ambitious in terms of volume and reach, providing for large-scale purchases of private, public, and quasi-public (agency) debt instruments - on top of massive funding support for other investors' asset purchases, notably under the US\$ 1,000 billion Term Asset-Backed Securities Loan Facility. The BoE's Asset Purchase Facility ranks second in terms of relative size. The Bank of Japan, in turn, has announced comparatively limited asset purchases, but is the only major central bank to also buy equities (from Japanese banks). Lastly, prospective ECB asset purchases are relatively small-scale and likely to be at least partly sterilized.

The cross-sectional variation in the scale and nature of asset purchases arguably reflects different economic circumstances as well as specific judgments about the costs and benefits of these operations. In principle, central bank asset purchases would be expected to be larger, the stronger the perceived need for monetary stimulus going beyond low policy rates; the more favorably the central bank assesses their expansionary impact compared to other unconventional policy tools, such as communication about future policy

\footnotetext{
${ }^{1}$ Prepared by Andre Meier, based on a forthcoming IMF Working Paper.
} 
rates or extended-term refinancing operations; and the less they are seen as posing risks to the operational independence of the central bank. The composition of asset purchases, in turn, will likely mirror differences in the size of private capital markets as well as different central bank attitudes toward credit risk.

Table: Outright Asset Purchases by Major Central Banks

\begin{tabular}{|c|c|c|c|c|}
\hline & $\begin{array}{l}\text { U.S. Federal } \\
\text { Reserve }\end{array}$ & Bank of England & Bank of Japan & $\begin{array}{l}\text { European Central } \\
\text { Bank }\end{array}$ \\
\hline Targeted Assets & $\begin{array}{l}\text { Government bonds, } \\
\text { mortgage-backed } \\
\text { securities, agency } \\
\text { bonds, commercial } \\
\text { paper }\end{array}$ & $\begin{array}{l}\text { Government bonds, } \\
\text { corporate bonds, } \\
\text { commercial paper }\end{array}$ & $\begin{array}{l}\text { Government bonds, } \\
\text { corporate bonds, } \\
\text { commercial paper, } \\
\text { equities }\end{array}$ & Covered bonds \\
\hline \multicolumn{5}{|l|}{ Amount of net purchases announced $1 /$} \\
\hline Billions of US\$ & 2,100 & 204 & 268 & 84 \\
\hline Percent of 2008 GDP & 14.7 & 8.7 & 5.2 & 0.7 \\
\hline Percent of July 2007 base money & 255.8 & 179.3 & 29.6 & 7.2 \\
\hline \multicolumn{5}{|l|}{ Net amount purchased since Sept. 2008 2/ } \\
\hline Billions of US\$ & 798 & 141 & 48 & 0 \\
\hline Percent of 2008 GDP & 5.6 & 6.0 & 0.9 & 0.0 \\
\hline Percent of July 2007 base money & 97.2 & 123.7 & 5.3 & 0.0 \\
\hline Share of govt. bonds in purchases (percent) & $18.33 /$ & 96.7 & 92.1 & 0.0 \\
\hline
\end{tabular}

Sources: Federal Reserve Board; Bank of England; Bank of Japan; Haver Analytics; and IMF staff calculations.

1/ Based on announced maximum amounts of purchases through end-2009 for the U.S. Federal Reserve, the Bank of Japan, and the European Central Bank; and on announced target level of purchases through mid-August by the Bank of England. For U.S. Federal Reserve purchases of commercial paper, based on maximum holdings since inception of the relevant facility (CPFF).

2/ Data through June 10.

3/ Purchases of agency (Fannie Mae/Freddie Mac/Ginnie Mae) bonds and agency-guaranteed bonds account for an additional 64.1 percent of total purchases thus far.

While conducting asset purchases at a large scale, the BoE has pursued a cautious approach with respect to credit risk. This is apparent from (i) its strong focus on government bonds, which account for more than 95 percent of all purchases so far; (ii) the targeting of only high-quality private sector assets; and (iii) the design of its private asset purchases as a mere backstop for private market activity: the BoE undertakes to buy at spreads that are calibrated to be above "normal" but below distressed levels, implying a decline in purchases as market conditions have normalized in recent weeks. The BoE's conservative approach is noteworthy, as it coincides with exemplary protection against balance sheet risk, i.e., through explicit, comprehensive, and ex ante indemnity assurances from the fiscal authority. Thus, the BoE's operations are designed not only to limit financial damage to its balance sheet - a concern that circumscribes the room for maneuver in all central banks bent on preserving operational independence-but also to contain reputational risk and avoid assuming quasi-fiscal responsibilities, such as providing (implicit) subsidies to private agents.

At the same time, the relative effectiveness of government bond purchases is an open question. One important channel for central bank asset purchases to affect economic activity is by directly boosting asset valuations, or reducing market interest rates. The BoE's gilt purchases are very sizeable relative to the initial stock outstanding in the targeted segment (text chart), suggesting some potential to affect prices. However, yields can ultimately fall on a sustained basis only (i) if the central bank convinces agents to expect a lower path of future 
short-term rates or (ii) if risk premia representing liquidity, term, or credit risk come down. Large-scale buying of gilts could be construed as an implicit statement about future shortterm rates, thus aiming for the same expectational effects as the Fed's explicit communications strategy or the ECB's extension of fixed-rate refinancing operations to longer maturities. As regards risk premia, however, the gilt market arguably was not far out of line when the BoE purchases started, at least compared to the very high spreads in many private asset markets. Accordingly, the direct valuation effects triggered by government bond purchases might be more limited than they would be in more dysfunctional and less liquid credit markets. While this does not rule out stimulatory effects through other transmission channels (e.g., a rise in inflation expectations, or increased bank lending), it suggests that central bank asset purchases may also be faced with a fundamental risk-effectiveness trade-off.

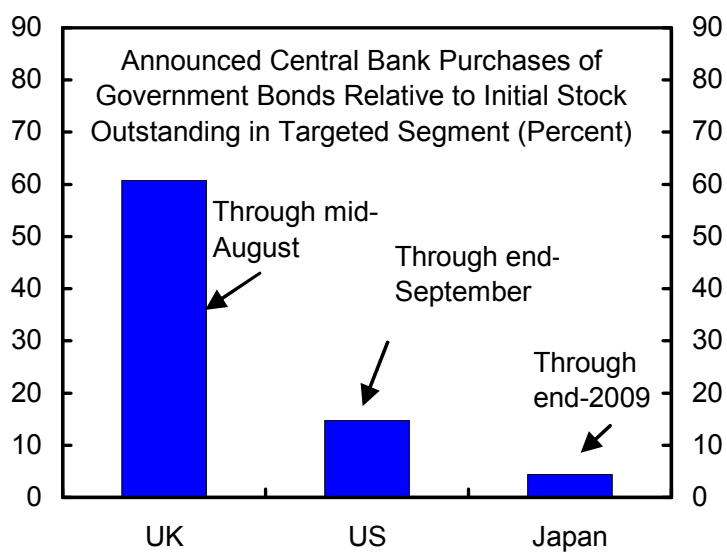

Sources: UK Debt Management Office; US Treasury; Japanese Ministry of Finance; and staff calculations. 1/ UK: Nominal gilts (excluding central government holdings) with remaining maturities of 5-25 years; US: marketable treasury notes, bonds, and TIPs with remaining maturies of 2-10 years; Japan: JGBs held outside of general government and Bank of Japan. 


\section{Annex V. Public Debt Sustainability ${ }^{1}$}

The UK's public debt indicators were favorable at the outset of the crisis (Figure A1). Debt levels in the UK were below the average of European peers and the debt portfolio is characterized by long maturities and minimal rollover amounts. A broad range of debt instruments and placement mechanisms is available to ensure successful funding of government operations.

However, general government gross debt is projected to increase from 43 percent of GDP in 2007/08 to about 100 percent of GDP by 2014/15. The baseline scenario for this debt sustainability analysis builds on staff's central scenario and focuses on general government gross debt (see Box A1). The primary deficit will peak at 11.1 percent of GDP in 2009/10, premised on the adjustment path outlined in Budget 2009, and is forecast to decline gradually to 1.4 percent of GDP by $2015 / 16$, when it reaches the debt stabilizing level (Table A1). Gross financing needs in the near term are high — they are expected to reach 18 percent of GDP in 2010/11, driven by the high overall deficit, amortization, and an increased share of short term debt.

Alternative scenarios and bound tests highlight the uncertainties surrounding the projected debt path (Figure A2a). Higher interest rates, different growth scenarios, and assumptions on primary balances as outlined below significantly affect debt outcomes. Customized bound tests further show the debt dynamics resulting from the recognition of contingent liabilities, unwinding existing financial sector interventions, and additional bank recapitalization. In particular:

- Interest rate. Real interest rates in the baseline scenario are assumed to average 1.5 percent over the projection period, reflecting the current low interest rate environment. Nonetheless, interest expenditure is projected to rise significantly as a share of total expenditure. Should real interest rates increase above the historical average of 3.2 and reach 3.5 percent, debt would increase to 108 percent of GDP by 2014/15, some 8 percentage points of GDP above the baseline.

- Growth. Assuming expenditure plans remain unchanged, the debt-to-GDP ratio could reach 109 percent of GDP by 2014/15 should growth be $1 / 2$ percentage point lower each year. Likewise, under a more favorable upside growth scenario $(1 / 2$ percentage point higher each year) the debt-to-GDP ratio could fall to 96 percent.

- Contingent liabilities. Losses on guarantees issued to support the financial sector during 2008/09 could increase debt by 7 percent of GDP, assuming that net losses total 14 percent on the $£ 777$ billion, distributed over 5 years. In a more pessimistic scenario, where losses reach 28 percent, the debt-to-GDP ratio could rise by 13 percent of GDP. ${ }^{2}$

- Unwinding existing direct financial sector support. Reversing the (cash) bank recapitalization undertaken in 2008/09 has upside risks to debt of up to 6 percentage

\footnotetext{
1 Prepared by Fabian Bornhorst.

2 Estimates of loss rates are from IMF (2009) "Companion Paper-The State of Public Finances-Outlook and Medium-Term Policies after the 2008 Crisis” http://www.imf.org/external/np/pp/eng/2009/030609a.pdf
} 
- points. Figure A2b compares two exit strategies where shares are disposed of over the next 5 years at purchase price or at double the purchase price. Should shares become worthless, gross government debt would remain unchanged but the public sector's net worth would decrease.

- Further direct financial sector support. The potential impact of further public capital provision is illustrated in Figure A2b. Specifically, the scenario assumes that an additional $£ 88$ billion in public capital would be provided (see Box 2), increasing the debt-to-GDP ratio to 105 percent by $2014 / 15$.

Treasury's indemnification of the Bank of England from any losses incurred in connection with the conduct of monetary policy is not included in this analysis. Any losses from the Special Liquidity Scheme are expected to be very low, given the high quality of the purchased assets, the amount of collateral involved, and fees charged for participation. Potential losses on purchases under the Asset Purchase Facility are also not included in the analysis.

While practically all public debt is denominated in sterling, roughly one-third of gilts are held by foreigners. Foreign investors play an important role in the funding of the budget deficit. The sterling denomination protects the government from exchange rate risk; however, exchange rate expectations are an important determinant of overseas demand for UK securities.

Table A1. United Kingdom, General Government balances 2007-2016

\begin{tabular}{|c|c|c|c|c|c|c|c|c|c|}
\hline & $2007 / 08$ & $2008 / 09$ & $2009 / 10$ & $2010 / 11$ & $2011 / 12$ & $2012 / 13$ & $2013 / 14$ & $2014 / 15$ & $2015 / 16$ \\
\hline & \multicolumn{9}{|c|}{ in percent of GDP } \\
\hline Overall balance & -2.7 & -7.0 & -13.1 & -13.3 & -10.8 & -9.0 & -7.5 & -6.7 & -5.2 \\
\hline Current balance & -0.6 & -3.8 & -9.9 & -10.9 & -8.9 & -7.4 & -6.2 & -5.4 & -3.9 \\
\hline Primary balance (excl. interest revenue) & -0.6 & -4.8 & -11.1 & -10.3 & -7.6 & -5.6 & -3.9 & -2.8 & -1.4 \\
\hline
\end{tabular}




\section{Box A1. Which measure of debt?}

This debt sustainability analysis focuses on the consolidated gross debt of the general government. Financial sector interventions and monetary policy conduct render other measures of public sector debt less informative when assessing the sustainability of government operations. Gross general government debt closely tracks the Maastricht treaty definition of debt. It includes the gross cash cost of financial sector interventions (which are excluded from the public sector net debt unless specifically noted). ${ }^{1}$ The pending statistical classification of RBS and Lloyds as public sector corporations will cause public sector net debt to increase dramatically since only a small fraction of the banks' assets count towards public sector liquid assets. The pending statistical treatment of assets bought under the Bank of England's Asset Purchase Facility could also affect the public sector net debt measure.

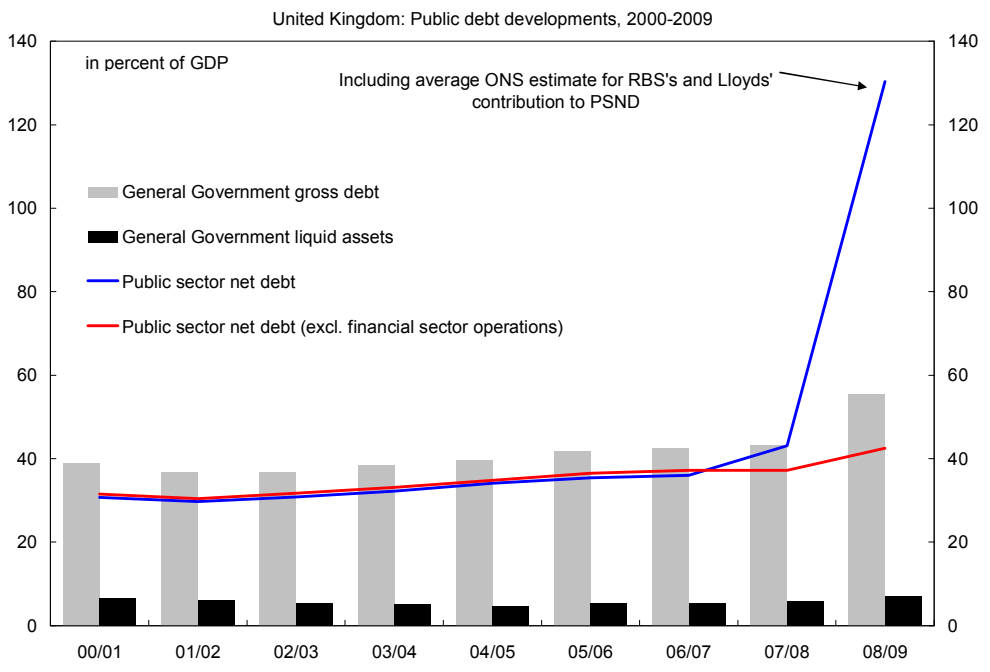

\footnotetext{
${ }^{1}$ Pending a decision from the Office for National Statistics, general government gross debt excludes Treasury bills created by HMT and lent the Bank of England to operate the Special Liquidity Scheme (13 percent of GDP)
} 
Figure A1. Europe: Debt Indicators, 2007-08.
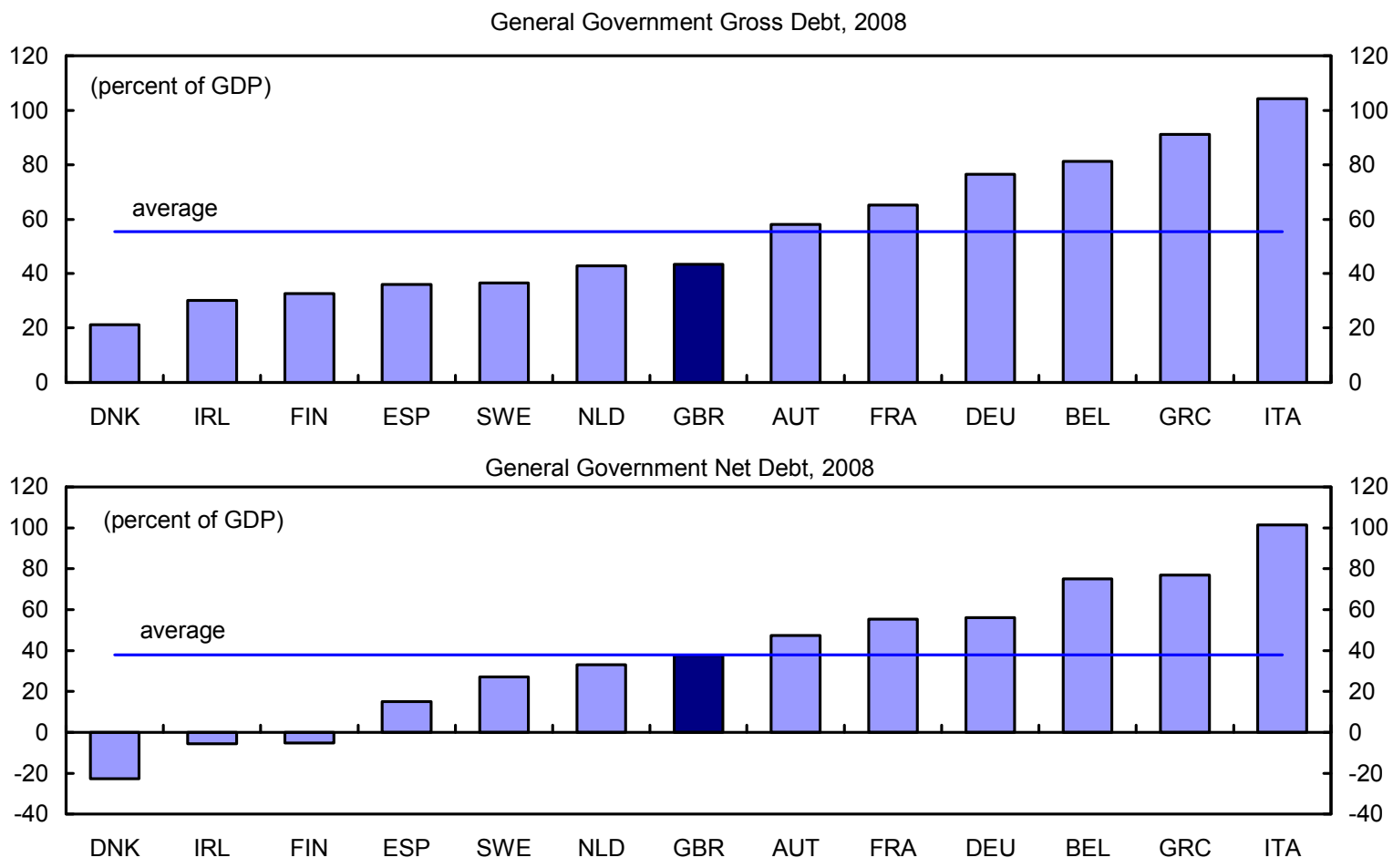

Average Maturity, 2007
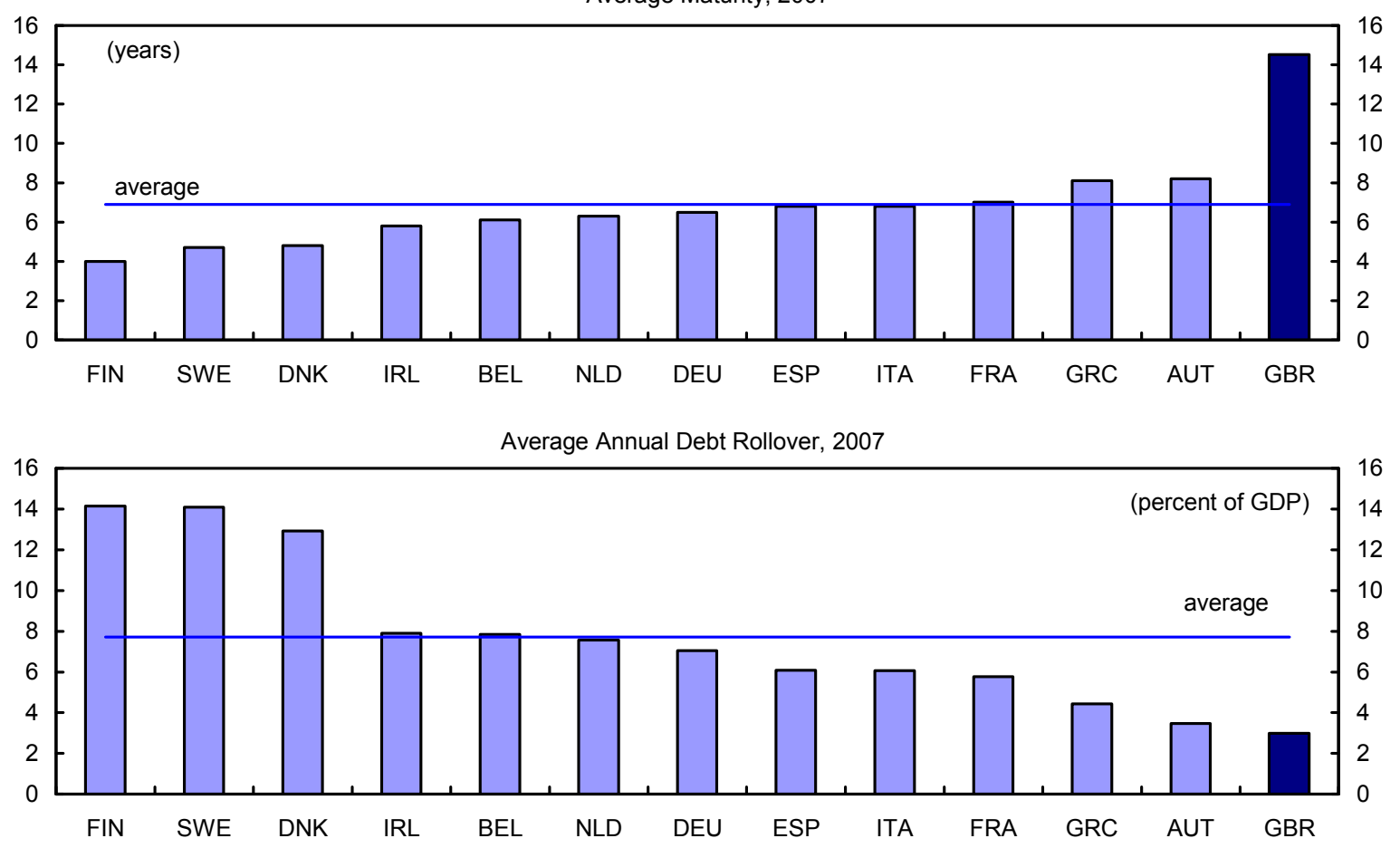

Source: WEO, staff estimates, and Karam and Jonas (2009). 
Figure A2a. United Kingdom: Public Debt Sustainability: Bound Tests 1/ (General government gross debt in percent of GDP)
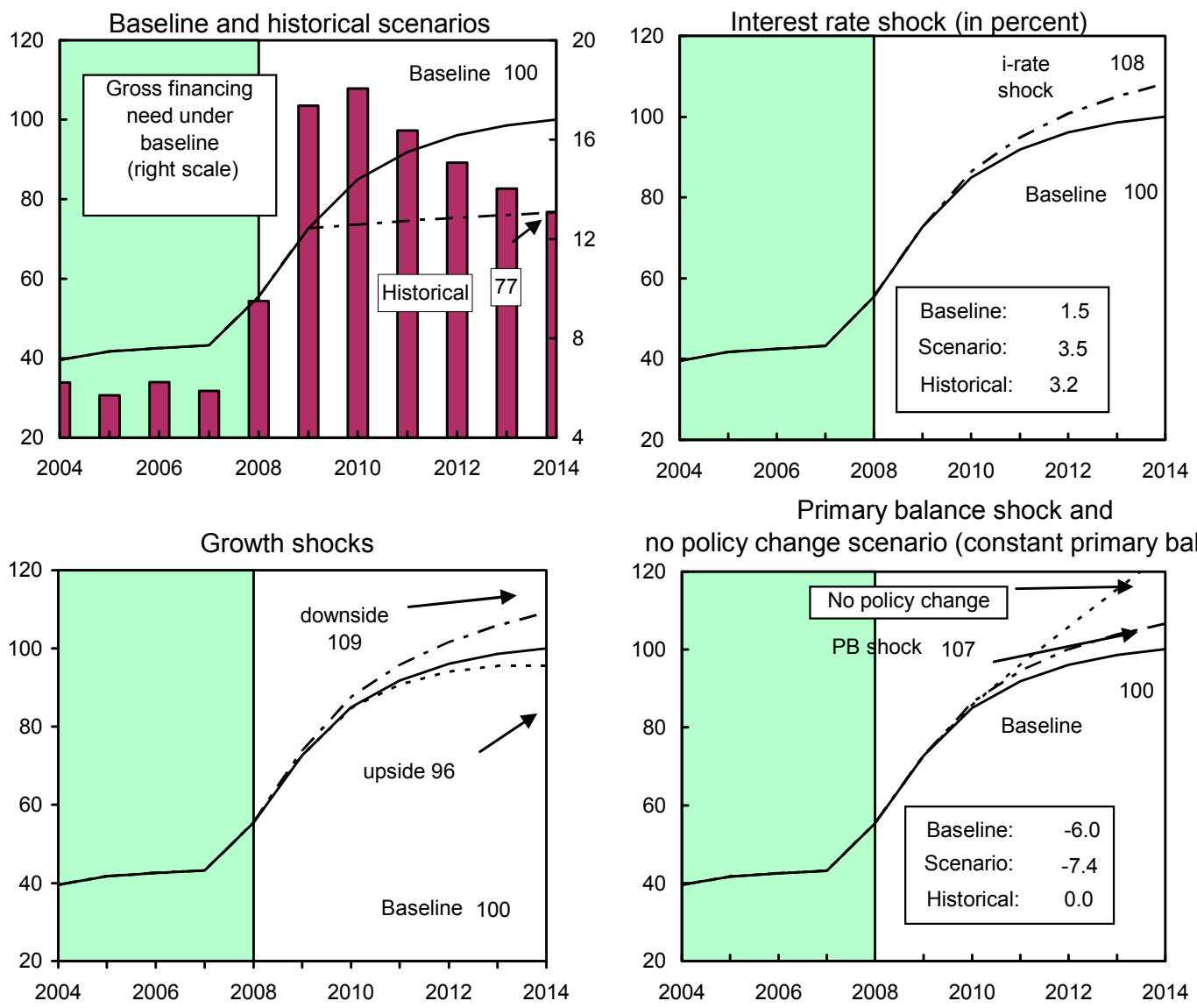

no policy change scenario (constant primary balance)
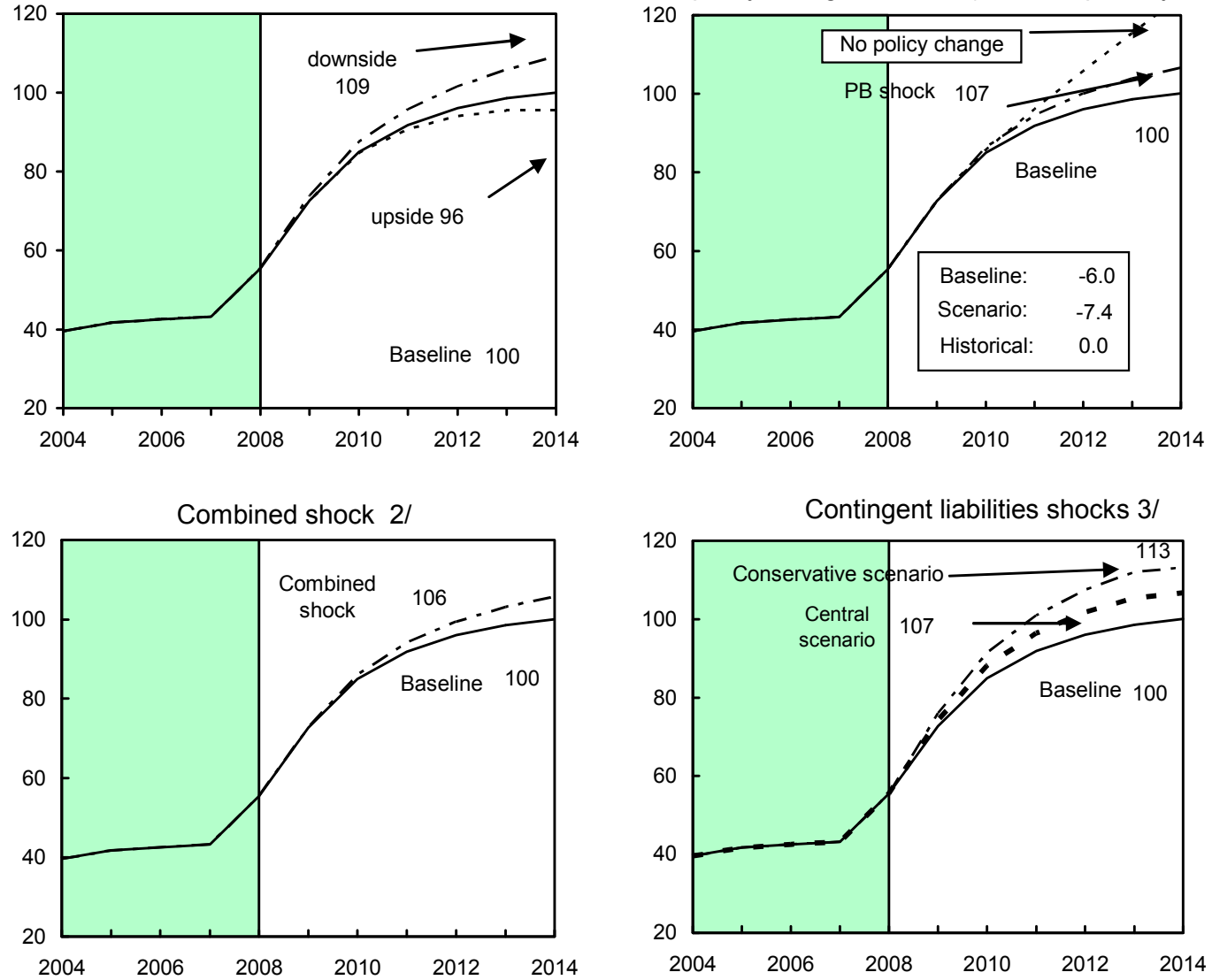

Sources: International Monetary Fund, country desk data, and staff estimates. Data for fiscal years.

1/ Shaded areas represent actual data. Shocks as defined in the text; interest rate shock: 2 standard deviations from 2010 onwards. Upside and downside growth scenarios as defined in the text. Figures in the boxes represent average projections for the respective variables in the baseline and scenario being presented. Ten-year historical average for the variable is also shown.

2/ Permanent $1 / 4$ standard deviation shocks applied to real interest rate, growth rate, and primary balance.

$3 /$ Contingent liabilities. Central scenario assumes losses totalling 14 percent on explicitly assumed guarantees for financial sector interventions incurred in 2008/09, distributed over 5 years. Conservative scenario assumes losses totalling 28 percent. 
Figure A2b. United Kingdom: Public Debt Sustainability: Bound Tests 1/ (General government gross debt in percent of GDP)
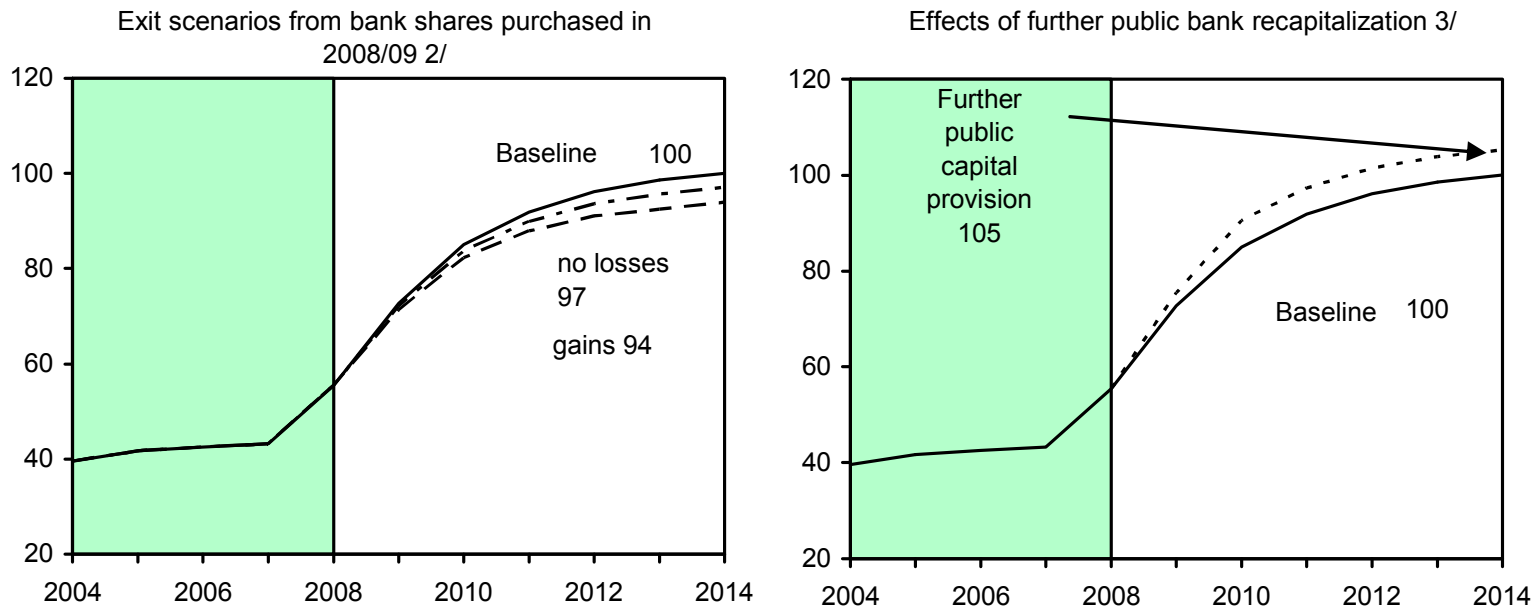

Sources: International Monetary Fund, country desk data, and staff estimates. Data for fiscal years.

$1 /$ Shaded areas represent actual data.

2/ Assumes sale of regular shares in financial institutions purchased in 2008/09 at (i) purchase price (ii) double the purchase price.

3/ Assumes additional public capital injections of GBP 88 billion (see Box 2). 
Table A2. United Kingdom: Public Sector Debt Sustainability Framework, 2004-2014

(In percent of GDP, unless otherwise indicated)

\begin{tabular}{|c|c|c|c|c|c|c|c|c|c|c|c|c|}
\hline & \multicolumn{5}{|c|}{ Actual } & \multicolumn{6}{|c|}{ Projections } & \multirow{3}{*}{$\begin{array}{c}\text { Debt-stabilizing } \\
\text { primary } \\
\text { balance } 9 /\end{array}$} \\
\hline & 2004 & 2005 & 2006 & 2007 & 2008 & 2009 & 2010 & 2011 & 2012 & 2013 & 2014 & \\
\hline & & & & & & & & & & & & \\
\hline Baseline: Public sector debt $1 /$ & 39.6 & 41.7 & 42.5 & 43.2 & 55.4 & 72.7 & 85.0 & 91.9 & 96.1 & 98.6 & 100.0 & -1.4 \\
\hline $\mathrm{o} / \mathrm{w}$ foreign-currency denominated & 0.1 & 0.1 & 0.1 & 0.1 & 0.1 & 0.0 & 0.0 & 0.0 & 0.0 & 0.0 & 0.0 & \\
\hline Change in public sector debt & 1.2 & 2.1 & 0.8 & 0.7 & 12.2 & 17.3 & 12.3 & 6.9 & 4.2 & 2.5 & 1.5 & \\
\hline Identified debt-creating flows $(4+7+12)$ & 1.5 & 1.3 & 0.3 & 0.5 & 6.6 & 14.2 & 11.9 & 6.5 & 3.9 & 2.4 & 1.5 & \\
\hline Primary deficit & 1.4 & 0.9 & 0.5 & 0.6 & 4.8 & 11.1 & 10.3 & 7.6 & 5.6 & 3.9 & 2.8 & \\
\hline Revenue and grants & 36.7 & 37.6 & 38.1 & 38.1 & 37.1 & 34.5 & 35.3 & 36.3 & 36.9 & 37.1 & 37.3 & \\
\hline Primary (noninterest) expenditure & 38.1 & 38.6 & 38.6 & 38.7 & 41.9 & 45.6 & 45.6 & 43.9 & 42.5 & 41.0 & 40.1 & \\
\hline Automatic debt dynamics $2 /$ & 0.0 & 0.4 & -0.2 & 0.0 & 1.8 & 3.1 & 1.5 & -1.1 & -1.6 & -1.5 & -1.3 & \\
\hline Contribution from interest rate/growth differential $3 /$ & 0.0 & 0.4 & -0.2 & 0.0 & 1.7 & 3.1 & 1.5 & -1.1 & -1.6 & -1.5 & -1.3 & \\
\hline Of which contribution from real interest rate & 1.0 & 1.3 & 0.9 & 1.0 & 1.2 & 1.4 & 1.9 & 1.0 & 0.9 & 1.0 & 1.2 & \\
\hline Of which contribution from real GDP growth & -0.9 & -1.0 & -1.1 & -1.0 & 0.5 & 1.7 & -0.4 & -2.1 & -2.5 & -2.5 & -2.6 & \\
\hline Contribution from exchange rate depreciation $4 /$ & 0.0 & 0.0 & 0.0 & 0.0 & 0.0 & & & & & & & \\
\hline Other identified debt-creating flows & 0.0 & 0.0 & 0.0 & 0.0 & 0.0 & 0.0 & 0.0 & 0.0 & 0.0 & 0.0 & 0.0 & \\
\hline Privatization receipts (negative) & 0.0 & 0.0 & 0.0 & 0.0 & 0.0 & 0.0 & 0.0 & 0.0 & 0.0 & 0.0 & 0.0 & \\
\hline Recognition of implicit or contingent liabilities & 0.0 & 0.0 & 0.0 & 0.0 & 0.0 & 0.0 & 0.0 & 0.0 & 0.0 & 0.0 & 0.0 & \\
\hline Other (specify, e.g. bank recapitalization) & 0.0 & 0.0 & 0.0 & 0.0 & 0.0 & 0.0 & 0.0 & 0.0 & 0.0 & 0.0 & 0.0 & \\
\hline Residual, including asset changes (2-3) 5/ & -0.2 & 0.8 & 0.5 & 0.2 & 5.6 & 3.0 & 0.4 & 0.4 & 0.3 & 0.1 & 0.0 & \\
\hline Public sector debt-to-revenue ratio $1 /$ & 107.9 & 110.9 & 111.8 & 113.4 & 149.6 & 210.6 & 241.0 & 252.7 & 260.6 & 265.5 & 268.0 & \\
\hline Gross financing need 6 / & 6.2 & 5.7 & 6.2 & 5.9 & 9.5 & 17.4 & 18.1 & 16.4 & 15.1 & 14.0 & 13.1 & \\
\hline in billions of U.S. dollars & 138.8 & 131.9 & 154.4 & 166.8 & 260.9 & 447.6 & 477.7 & 459.0 & 450.3 & 445.3 & 441.1 & \\
\hline Scenario with key variables at their historical averages $7 /$ & & & & & & 72.7 & 73.7 & 74.6 & 75.4 & 76.1 & 76.6 & 0.6 \\
\hline Scenario with no policy change (constant primary balance) in 2009-2014 & & & & & & 72.7 & 85.7 & 96.1 & 105.8 & 115.3 & 124.9 & -1.7 \\
\hline \multicolumn{13}{|l|}{ Key Macroeconomic and Fiscal Assumptions Underlying Baseline } \\
\hline Real GDP growth (in percent) & 2.5 & 2.5 & 2.7 & 2.6 & -1.1 & -3.0 & 0.5 & 2.6 & 2.9 & 2.8 & 2.7 & \\
\hline Average nominal interest rate on public debt (in percent) $8 /$ & 5.5 & 5.4 & 5.3 & 5.4 & 5.1 & 3.5 & 4.2 & 4.0 & 3.9 & 4.0 & 4.2 & \\
\hline Average real interest rate (nominal rate minus change in GDP deflator, in percent) & 2.7 & 3.6 & 2.3 & 2.6 & 2.9 & 2.5 & 2.6 & 1.3 & 1.1 & 1.2 & 1.4 & \\
\hline Nominal appreciation (increase in US dollar value of local currency, in percent) & 8.2 & -10.8 & 14.0 & 2.1 & -27.2 & & & 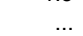 & & & & \\
\hline Inflation rate (GDP deflator, in percent) & 2.8 & 1.9 & 3.0 & 2.8 & 2.2 & 1.0 & 1.5 & 2.7 & 2.8 & 2.8 & 2.8 & \\
\hline Growth of real primary spending (deflated by GDP deflator, in percent) & 4.7 & 3.7 & 2.7 & 2.9 & 7.0 & 5.7 & 0.4 & -1.1 & -0.5 & -0.8 & 0.5 & \\
\hline Primary deficit & 1.4 & 0.9 & 0.5 & 0.6 & 4.8 & 11.1 & 10.3 & 7.6 & 5.6 & 3.9 & 2.8 & \\
\hline
\end{tabular}

1/ General government consolidated gross debt (series: BKPX)

2/ Derived as $[(r-\pi(1+g)-g+\alpha \varepsilon(1+r)] /(1+g+\pi+g \pi))$ times previous period debt ratio, with $r=$ interest rate; $\pi=$ growth rate of GDP deflator; $g=$ real GDP growth rate; $\alpha=$ share of foreign-currency

denominated debt; and $\varepsilon=$ nominal exchange rate depreciation (measured by increase in local currency value of U.S. dollar).

$3 /$ The real interest rate contribution is derived from the denominator in footnote $2 /$ as $r-\pi(1+g)$ and the real growth contribution as $-g$.

4/ The exchange rate contribution is derived from the numerator in footnote $2 /$ as $\alpha \varepsilon(1+r)$

$6 /$ Defined as the general government deficit, plus amortization of medium and long-term public sector debt, plus short-term debt at end of previous period

7/ The key variables include real GDP growth; real interest rate; and primary balance in percent of GDP.

8/ Derived as nominal interest expenditure divided by previous period debt stock.

9/ Assumes that key variables (real GDP growth, real interest rate, and other identified debt-creating flows) remain at the level of the last projection year. 
United Kingdom: Selected Economic and Social Indicators

\begin{tabular}{|c|c|c|c|c|c|c|}
\hline & 2005 & 2006 & 2007 & 2008 & $\begin{array}{l}2009 \\
\text { Proj. }\end{array}$ & $\begin{array}{l}2010 \\
\text { Proj. }\end{array}$ \\
\hline \multicolumn{7}{|l|}{ Real Economy } \\
\hline Real GDP (change in percent) & 2.2 & 2.9 & 2.6 & 0.7 & -4.2 & 0.2 \\
\hline Domestic demand (change in percent) & 2.1 & 2.4 & 3.0 & 0.5 & -5.0 & -0.3 \\
\hline $\mathrm{CPI}$ & 2.1 & 2.3 & 2.3 & 3.6 & 1.7 & 1.3 \\
\hline Unemployment rate (in percent) $1 /$ & 4.8 & 5.4 & 5.4 & 5.5 & 7.6 & 9.2 \\
\hline Gross national saving (percent of GDP) & 14.5 & 14.2 & 15.6 & 15.3 & 11.8 & 12.4 \\
\hline Gross domestic investment (percent of GDP) & 17.1 & 17.5 & 18.3 & 17.0 & 14.1 & 14.4 \\
\hline \multicolumn{7}{|l|}{ Public Finance 2/ } \\
\hline General government balance & -3.0 & -2.6 & -2.7 & -7.0 & -13.1 & -13.3 \\
\hline Public sector balance & -3.0 & -2.3 & -2.4 & -6.1 & -12.8 & -13.1 \\
\hline Cyclically adjusted balance (staff estimates) & -2.8 & -2.2 & -2.8 & -5.5 & -9.9 & -9.5 \\
\hline Public sector net debt & 35.6 & 36.2 & 36.5 & 42.1 & 56.4 & 67.9 \\
\hline \multicolumn{7}{|l|}{ Money and Credit (end-period, 12-month percent change) } \\
\hline M4 & 12.8 & 12.5 & 12.3 & 16.4 & 17.4 & $\ldots$ \\
\hline Consumer Credit & 9.6 & 7.4 & 7.0 & 4.5 & 2.1 & $\ldots$ \\
\hline \multicolumn{7}{|l|}{ Interest rates (year average) } \\
\hline Three-month interbank rate & 4.7 & 5.3 & 6.0 & 5.5 & 1.9 & $\ldots$ \\
\hline Ten-year government bond yield & 4.4 & 4.5 & 5.0 & 4.6 & 3.5 & $\ldots$ \\
\hline \multicolumn{7}{|l|}{ Balance of Payments } \\
\hline Trade balance (in percent of GDP) & -3.4 & -3.1 & -3.2 & -2.7 & -2.3 & -2.0 \\
\hline Current account balance (in percent of GDP) & -2.6 & -3.3 & -2.7 & -1.7 & -2.2 & -2.0 \\
\hline Exports (percent of GDP) & 26.4 & 28.5 & 26.6 & 29.1 & 26.7 & 27.2 \\
\hline Export volume (change in percent) & 7.9 & 11.3 & -2.8 & 0.8 & -12.9 & 0.7 \\
\hline Imports (percent of GDP) & 29.8 & 31.6 & 29.8 & 31.8 & 29.0 & 29.2 \\
\hline Import volume (change in percent) & 7.1 & 8.8 & -0.7 & -0.6 & -14.2 & -1.0 \\
\hline Net exports of oil (in billions of US dollars) & -4.0 & -5.1 & -8.1 & -10.1 & -4.9 & -6.1 \\
\hline Reserves (end of period, in billion of US dollars) & 46.2 & 51.8 & 57.2 & 53.9 & $\ldots$ & $\ldots$ \\
\hline \multicolumn{7}{|l|}{ Fund Position (as of April 30, 2009) } \\
\hline Holdings of currency (in percent of quota) & & & & & & 86.3 \\
\hline Holdings of SDRs (in percent of allocation) & & & & & & 15.2 \\
\hline Quota (in millions of SDRs) & & & & & & $10,738.5$ \\
\hline \multicolumn{7}{|l|}{ Exchange Rates } \\
\hline Exchange rate regime & & & & & & $\begin{array}{l}\text { Floating } \\
\text { US } \$=\end{array}$ \\
\hline Bilateral rate (May 26, 2009) & & & & & & $£ 0.6272$ \\
\hline Nominal effective rate $(2000=100) 3 /$ & 100.0 & 100.8 & 103.1 & 90.9 & 78.4 & $\ldots$ \\
\hline Real effective rate $(2000=100) 3 / 4 /$ & 101.4 & 103.2 & 108.0 & 95.0 & 80.5 & $\ldots$ \\
\hline \multicolumn{7}{|c|}{$\begin{array}{l}\text { Social Indicators (reference year): } \\
\text { Income per capita (in US dollars, 2007) : 46.716; Income distribution (ratio of income received by top and bottom quintiles, 2007): } 5.5 \text {; } \\
\text { Life expectancy at birth (2005): } 77.1 \text { (male) and } 81.1 \text { (female); Automobile ownership (2004): } 463 \text { per thousand; } \\
\text { CO2 emissions (ton per capita, 2005): } 9.26 \text {; Population density (2007) } 252 \text { inhabitants per sq. km.; } \\
\text { Poverty rate (at-risk-of-poverty rate after social transfers, } 2007): 19 \% \text {. }\end{array}$} \\
\hline
\end{tabular}

Sources: National Statistics; HM Treasury; Bank of England; International Financial Statistics; INS; World Development Indicators; and IMF staff estimates.

1/ ILO unemployment; based on Labor Force Survey data.

2/ The fiscal year begins in April. For example, fiscal balance data for 2002 refers to FY2002/03. Debt stock data refers to the end of the fiscal year using centered-GDP as a denominator.

3/ Average. An increase denotes an appreciation.

4/ Based on Consumer Price data. 


\section{INTERNATIONAL MONETARY FUND UNITED KINGDOM}

\section{Staff Report for the 2009 Article IV Consultation-Informational Annex}

Prepared by the Staff Representatives for the 2009 Consultation with the United Kingdom

$$
\text { (In consultation with other departments) }
$$

June 23, 2009

Contents

I. Fund Relations .2 
Annex I. United Kingdom: Fund Relations

(As of May 31, 2009)

I. Membership Status: Joined 12/27/1945; Article VIII

II. General Resources Account:

SDR Million

$10,738.50$

$8,618.57$

$2,120.02$

Fund holdings of currency

Reserve position in Fund

III. SDR Department:

Net cumulative allocation

Holdings

Designation Plan

IV. Outstanding Purchases and Loans:

V. Financial Arrangements:

SDR Million

$1,913.07$

287.37

0.00

\author{
Percent Quota \\ 100.00 \\ 80.26 \\ 19.74
}

Percent Allocation

100.00

15.02

VI. Projected Obligation to Fund: (SDR million; based on present holdings of SDRs):

Forthcoming

Principle

Charges/Interest

Total

None

None 
VIII. Article IV Consultation:

Discussions for the 2009 Article IV consultation were conducted in London during May 7-20, 2009. The Staff Report (IMF Country Report) was considered by the Executive Board on July 10, 2009.

IX. FSAP

The FSAP was completed at the time of the 2002 Article IV Consultation.

X. Technical Assistance: None

XI. Resident Representative: None 


\section{Statement by the IMF Staff Representative on the United Kingdom July 10, 2009}

1. This statement provides information that has become available since the Staff Report was circulated to the Executive Board on June 25, 2009. The information does not alter the staff's broad assessment of policy issues and recommendations contained in the staff report.

2. On July 8, the UK Treasury released a white paper, which lays out a strategy for further regulatory reform (http://www.hm-reasury.gov.uk/reforming financial markets.htm). The following priorities are identified in the paper:

- Strengthening the UK's regulatory institutional framework. The white paper endorses the current tripartite arrangement, but the government seeks to strengthen its operation and risk assessment capacity by creating a "Council for Financial Stability" to replace the existing standing committee. Further, the government intends to provide the FSA with a formal, statutory objective for financial stability, along with clearer legal authority to take into account systemic implications when setting prudential rules. The FSA would also obtain enhanced regulatory powers to deal with misconduct, and a possible extension of its information gathering powers to support its more intensive supervisory approach. Deposit insurance would transit to a prefunded system over the medium term.

- Dealing with systemically important financial institutions. The white paper rejects proposals to impose regulatory limits on the size or complexity of financial firms. Instead, the government's approach rests on better market discipline, notably through reforms to corporate governance and remuneration policies, and an enhanced supervisory focus on "high impact" firms that may be seen as being "too big to fail." Such firms would be required to prepare detailed practical plans for their own resolution in case of failure, and be subject to more stringent regulation, including higher capital and liquidity requirements.

- Greater emphasis on monitoring and managing system-wide risks. The white paper stresses the need to improve transparency, including through more consistent accounting and valuation standards, and to make wholesale markets more robust, especially for securitization and over-the-counter derivatives. Efforts would concentrate on promoting standardization and central counterparty arrangements. Moreover, the government supports the development of macroprudential tools - both rules-based and discretionary - to counteract the build-up of large systemic risks.

- Close cooperation with international partners to deliver regulatory reform in areas where a coordinated approach is required. This covers, notably, the government's support for key recommendations from the Turner Review, i.e., to mandate more and higher-quality capital requirements, introduce a backstop leverage ratio, enhance the regulation of liquidity, and develop macroprudential tools. The white paper also endorses 
the June 2009 European Council conclusions to strengthen the EU supervisory and regulatory framework.

3. To take the proposed program forward the government intends to consult with the FSA, the Bank of England, other relevant parties, and its international partners over the coming months. Concrete legislative action is envisaged to start later in 2009.

4. On June 25, the Bank of England released its latest Financial Stability Report (FSR), (http://www.bankofengland.co.uk/publications/fsr/2009/index.htm). The FSR notes that given their leverage and funding positions, banks in the UK (and internationally) will remain sensitive to further shocks for some time. Further, although private demand for non-guaranteed bank debt has begun to return, funding pressure is likely to persist in the coming years as banks need to secure substantial private financing to replace the current official funding support. If the economic recovery were to stall because of weak bank lending, losses on assets could rise, further affecting confidence in the banking sector. To increase the resilience of the financial system the FSR calls for stronger market discipline, including through more granular and frequent disclosure by banks; greater self-insurance, including by holding higher capital and liquidity buffers; and improved management of risks arising from interactions, including by improved information on connections between financial institutions and countercyclical prudential policy to limit the growth of financial imbalances.

5. The proposals put forth in the Treasury's white paper and the BoE's FSR complement those in the Turner Review (released in February 2009) and are consistent with the thrust of the staff report's recommendations. The UK authorities are encouraged to continue work on the implementation of the proposed actions in close collaboration with international partners. 


\section{INTERNATIONAL MONETARY FUND}

EXTERNAL

Public Information Notice

RELATIONS

DEPARTMENT

Public Information Notice (PIN) No. 09/84

International Monetary Fund

FOR IMMEDIATE RELEASE

$70019^{\text {th }}$ Street, NW

July 16, 2009

Washington, D. C. 20431 USA

\section{IMF Executive Board Concludes 2009 Article IV Consultation with the United Kingdom}

On July 10, 2009 the Executive Board of the International Monetary Fund (IMF) concluded the Article IV consultation with the United Kingdom. ${ }^{1}$

\section{Background}

The United Kingdom has been hit hard by the global financial crisis. The economy was particularly vulnerable to the crisis because of the large size of its financial sector, high household indebtedness, and strong cross-border links. Economic growth has turned sharply negative since mid-2008, house prices have fallen by more than 20 percent from their peak, the unemployment rate has increased and inflation has come down. Driven by increased risk perceptions, sterling has depreciated significantly between mid-2007 and early 2009, helping to narrow the UK's external imbalances, before regaining some strength in recent months. With banks focused on reducing leverage, the growth of credit to the private sector has fallen to nearly zero, and is expected to remain low in the near term.

In response to the crisis, the authorities have taken wide-ranging measures to stabilize the financial system and support demand. The measures included expansion of the Bank of England's liquidity facilities, significant public capital injections in several large banks, an Asset Protection Scheme to limit losses on troubled bank assets, and guarantees for banks' debt. Considerable policy stimulus has also been introduced to support the economy. The Bank of England reduced interest rates to a historic low of 0.5 percent by March 2009 and began purchasing assets, financed by an expansion of base money (quantitative easing). Meanwhile,

\footnotetext{
${ }^{1}$ Under Article IV of the IMF's Articles of Agreement, the IMF holds bilateral discussions with members, usually every year. A staff team visits the country, collects economic and financial information, and discusses with officials the country's economic developments and policies. On return to headquarters, the staff prepares a report, which forms the basis for discussion by the Executive Board. At the conclusion of the discussion, the Managing Director, as Chairman of the Board, summarizes the views of Executive Directors, and this summary is transmitted to the country's authorities.
} 
the government has put in place a discretionary fiscal stimulus package of around 2 percent of GDP. These policies have helped avert a systemic breakdown in the financial system, although vulnerabilities remain.

The crisis and the ensuing recession have led to a rapid deterioration of public finances. With revenues highly sensitive to the economic cycle, financial sector activity, and asset prices, fiscal deficits have widened sharply and are expected to be about 13 percent of GDP in 2009 and 2010. Gross general government debt is set to double over the next five years to nearly 100 percent of GDP. At the same time, contingent liabilities of the government have increased rapidly.

The economic outlook is highly uncertain. Recent indicators suggest that economic activity has begun to stabilize. However, the recovery is likely to be slow and subdued as banks and households go through a difficult balance sheet adjustment. GDP is expected to contract by 4.2 percent in 2009 , with growth picking up gradually in 2010 . As spare capacity continues to increase, inflation is expected to fall below the 2-percent target in the second half of 2009 and remain low for an extended period of time.

\section{Executive Board Assessment}

The Executive Directors noted that the UK economy has been hit hard by the global financial crisis and welcomed the UK authorities' aggressive policy response. The measures taken to stabilize the financial system have been successful in averting a systemic breakdown. The significant fiscal and monetary stimulus underway will help support activity in the near-term. There are tentative signs that economic activity is stabilizing. However, Directors pointed out that the outlook for the UK economy is highly uncertain and will depend on, among other factors, the pace and extent of deleveraging of financial institutions' and households' balance sheets.

Directors considered that, looking forward, the projected sharp increase in public debt, the accumulation of sizable contingent liabilities, and continued financial sector fragility represent significant vulnerabilities. They therefore emphasized the importance of following credible and consistent policies to maintain domestic and external stability, limit downside risks, and strengthen market confidence. Resolving the problems in the financial sector and setting monetary and fiscal policies consistent with a firm commitment to price stability and fiscal sustainability are the main policy priorities.

Directors stressed that the most important policy task remains repairing the financial system. Significant uncertainties remain about the adverse impact of the recession on asset quality. Substantial further write-downs would result in an erosion of capital buffers and might lead to renewed doubts about the capital adequacy of individual financial institutions. These lingering uncertainties are restraining lending growth. Directors suggested that the authorities should encourage banks to strengthen their capital base and explore options to improve capital 
structures. The authorities should also continue their contingency planning, and a number of Directors agreed that they should be prepared to provide further public capital, if needed.

Directors welcomed the adoption of the Special Resolution Regime for financial institutions and noted that its effective implementation would require timely and comprehensive information sharing and cooperation among the tripartite authorities. The UK authorities should continue to work with international partners, including the $\mathrm{EU}$, on strengthening cross-border financial stability arrangements and resolution frameworks, for example through the development of effective arrangements for crisis management and orderly exit of cross-border banks.

Directors supported a number of the proposals for enhancing the UK's prudential framework presented in the Turner Review and in the white paper on reforming financial markets published by the Treasury. In particular, Directors endorsed the proposed enhancement of liquidity regulation, the increased emphasis on identifying system-wide risks, and proposals for a Council for Financial Stability. They encouraged the authorities to continue working with international partners on the development of new macro-prudential instruments that could help mitigate the amplitude of credit cycles. Many Directors considered that a phased introduction of a maximum gross leverage ratio could act as a useful backstop against excessive balance sheet growth. Finally, Directors recommended improving the frequency and quality of disclosure of financial information by banks.

Executive Directors considered the Bank of England's strategy of aggressive monetary easing, aimed at maintaining inflation close to target, to be appropriate, while noting it is too early to judge the overall effectiveness of quantitative easing. Directors noted that diversifying the Bank of England's private asset purchases further could help improve the functioning of capital markets. They welcomed the robust institutional arrangement underpinning the Bank of England's unconventional operations, including comprehensive indemnity assurances from the Treasury. These arrangements preserve the Bank of England's operational independence and will help assure a smooth exit from quantitative easing when warranted by economic conditions.

Directors emphasized that the success of the current policy package depends on continued trust in the sustainability of the fiscal position. A strong commitment to reverse the sharp deterioration of the public finances once the economic recovery has been established, within the context of a coherent and ambitious fiscal framework, will be essential. The focus of fiscal consolidation plans should be on putting public debt on a firmly downward path within a reasonable timeframe. Credibility would be enhanced by specifying concrete expenditure and revenue measures to achieve the desired adjustment. Long-term sustainability would also be helped by implementing structural reforms to limit the rise in ageing-related costs. 
Public Information Notices (PINs) form part of the IMF's efforts to promote transparency of the IMF's views and analysis of economic developments and policies. With the consent of the country (or countries) concerned, PINs are issued after Executive Board discussions of Article IV consultations with member countries, of its surveillance of developments at the regional level, of post-program monitoring, and of ex post assessments of member countries with longer-term program engagements. PINs are also issued after Executive Board discussions of general policy matters, unless otherwise decided by the Executive Board in a particular case. The staff report (use the free Adobe Acrobat Reader to view this pdf file) for the 2009 Article IV Consultation with the United Kingdom is also available. 
United Kingdom: Selected Economic and Social Indicators

\begin{tabular}{|c|c|c|c|c|c|c|}
\hline & 2005 & 2006 & 2007 & 2008 & $\begin{array}{l}2009 \\
\text { Proj. }\end{array}$ & $\begin{array}{l}2010 \\
\text { Proj. }\end{array}$ \\
\hline \multicolumn{7}{|l|}{ Real Economy } \\
\hline Real GDP (change in percent) & 2.2 & 2.9 & 2.6 & 0.7 & -4.2 & 0.2 \\
\hline Domestic demand (change in percent) & 2.1 & 2.4 & 3.0 & 0.5 & -5.0 & -0.3 \\
\hline CPI & 2.1 & 2.3 & 2.3 & 3.6 & 1.7 & 1.3 \\
\hline Unemployment rate (in percent) $1 /$ & 4.8 & 5.4 & 5.4 & 5.5 & 7.6 & 9.2 \\
\hline Gross national saving (percent of GDP) & 14.5 & 14.2 & 15.6 & 15.3 & 11.8 & 12.4 \\
\hline Gross domestic investment (percent of GDP) & 17.1 & 17.5 & 18.3 & 17.0 & 14.1 & 14.4 \\
\hline \multicolumn{7}{|l|}{ Public Finance 2/ } \\
\hline General government balance & -3.0 & -2.6 & -2.7 & -7.0 & -13.1 & -13.3 \\
\hline Public sector balance & -3.0 & -2.3 & -2.4 & -6.1 & -12.8 & -13.1 \\
\hline Cyclically adjusted balance (staff estimates) & -2.8 & -2.2 & -2.8 & -5.5 & -9.9 & -9.5 \\
\hline Public sector net debt & 35.6 & 36.2 & 36.5 & 42.1 & 56.4 & 67.9 \\
\hline \multicolumn{7}{|c|}{ Money and Credit (end-period, 12-month percent change) } \\
\hline M4 & 12.8 & 12.5 & 12.3 & 16.4 & 17.4 & $\ldots$ \\
\hline Consumer Credit & 9.6 & 7.4 & 7.0 & 4.5 & 2.1 & $\ldots$ \\
\hline \multicolumn{7}{|l|}{ Interest rates (year average) } \\
\hline Three-month interbank rate & 4.7 & 5.3 & 6.0 & 5.5 & 1.9 & $\ldots$ \\
\hline Ten-year government bond yield & 4.4 & 4.5 & 5.0 & 4.6 & 3.5 & $\ldots$ \\
\hline \multicolumn{7}{|l|}{ Balance of Payments } \\
\hline Trade balance (in percent of GDP) & -3.4 & -3.1 & -3.2 & -2.7 & -2.3 & -2.0 \\
\hline Current account balance (in percent of GDP) & -2.6 & -3.3 & -2.7 & -1.7 & -2.2 & -2.0 \\
\hline Exports (percent of GDP) & 26.4 & 28.5 & 26.6 & 29.1 & 26.7 & 27.2 \\
\hline Export volume (change in percent) & 7.9 & 11.3 & -2.8 & 0.8 & -12.9 & 0.7 \\
\hline Imports (percent of GDP) & 29.8 & 31.6 & 29.8 & 31.8 & 29.0 & 29.2 \\
\hline Import volume (change in percent) & 7.1 & 8.8 & -0.7 & -0.6 & -14.2 & -1.0 \\
\hline Net exports of oil (in billions of US dollars) & -4.0 & -5.1 & -8.1 & -10.1 & -4.9 & -6.1 \\
\hline Reserves (end of period, in billion of US dollars) & 46.2 & 51.8 & 57.2 & 53.9 & $\ldots$ & $\ldots$ \\
\hline \multicolumn{7}{|l|}{ Fund Position (as of April 30, 2009) } \\
\hline Holdings of currency (in percent of quota) & & & & & & 86.3 \\
\hline Holdings of SDRs (in percent of allocation) & & & & & & 15.2 \\
\hline Quota (in millions of SDRs) & & & & & & $10,738.5$ \\
\hline \multicolumn{7}{|l|}{ Exchange Rates } \\
\hline Exchange rate regime & & & & & & $\begin{array}{l}\text { Floating } \\
\text { US } \$=\end{array}$ \\
\hline Bilateral rate (May 26, 2009) & & & & & & $£ 0.6272$ \\
\hline Nominal effective rate $(2000=100) 3 /$ & 100.0 & 100.8 & 103.1 & 90.9 & 78.4 & $\ldots$ \\
\hline Real effective rate $(2000=100) 3 / 4 /$ & 101.4 & 103.2 & 108.0 & 95.0 & 80.5 & $\ldots$ \\
\hline \multicolumn{7}{|c|}{$\begin{array}{l}\text { Income per capita (in US dollars, } 2007): 46.716 ; \text { Income distribution (ratio of income received by top and bottom quintiles, } 2007 \text { ): } 5.5 \text {; } \\
\text { Life expectancy at birth (2005): } 77.1 \text { (male) and } 81.1 \text { (female); Automobile ownership (2004): } 463 \text { per thousand; } \\
\text { CO2 emissions (ton per capita, 2005): } 9.26 \text {; Population density (2007) } 252 \text { inhabitants per sq. km.; } \\
\text { Poverty rate (at-risk-of-poverty rate after social transfers, } 2007 \text { ): } 19 \% \text {. }\end{array}$} \\
\hline
\end{tabular}

Sources: National Statistics; HM Treasury; Bank of England; International Financial Statistics; INS; World Development Indicators; and IMF staff estimates.

1/ ILO unemployment; based on Labor Force Survey data.

2/ The fiscal year begins in April. For example, fiscal balance data for 2002 refers to FY2002/03. Debt stock data refers to the end of the fiscal year using centered-GDP as a denominator.

3/ Average. An increase denotes an appreciation.

4/ Based on Consumer Price data. 


\section{Statement by Alex Gibbs, Executive Director for the United Kingdom July 10, 2009}

My authorities held a very open and productive consultation with the IMF staff Mission in May. They agree with the broad thrust of the staff report, and in particular welcome its support for the strength of the UK's policy response to the global crisis. The staff report rightly identifies the exceptional uncertainties that characterise policymaking in the current environment, as well as the longer term challenges that will need to be addressed once the crisis has passed. My statement seeks to complement the staff report by setting out my authorities' approach to these issues in more detail and noting some areas where views differ.

\section{Outlook and recent developments}

The UK economy has contracted in the period since the last Article IV in July 2008. Whilst the outlook remains subject to significant uncertainties, the forecast set out in the Treasury's April 2009 Budget is for a $-3 \frac{3}{4}$ to $-3 \frac{1}{4}$ percent reduction in GDP in 2009, followed by a 1 to $1 \frac{1}{2}$ percent growth in 2010 . In addition, the Treasury assumed a phased downward adjustment to the trend level of output of around 5 percent. However, as spare capacity in the economy is brought back to productive use by 2011 , GDP is forecast to grow by $3 \frac{1}{2}$ percent.

The economic outlook is, of course, highly uncertain at the current juncture and there are risks both to the upside and downside as highlighted by the IMF staff. Nevertheless, my

authorities see some potential reasons for growth to recover more quickly than staff forecast:

- the effect of the unprecedented and aggressive policy stimulus is expected to increasingly take hold;

- $\quad$ despite the recent contraction of global demand, the lower level of sterling should shift both domestic and overseas expenditure towards UK goods and services;

- $\quad$ the UK is already at a well-advanced stage in the inventory cycle, which should act to boost, rather than detract from, growth in the coming quarters;

- $\quad$ to the extent that the deterioration in financial conditions has acted to weigh on economic activity in the downswing, the normalisation of credit conditions as a result of the UK's financial sector interventions should act as a bulwark to growth in the upswing;

- $\quad$ although we agree with staff that uncertainty around employment prospects could slow recovery, we expect the UK's flexible labour market to allow firms, households and consumers to adjust relatively rapidly.

The latest Budget inflation forecast is broadly in line with the IMF Staff forecast for 2009 and 2010. My authorities agree that strong downward pressure from increasing spare capacity and lower energy prices means that CPI inflation will continue to ease, moving well below its target of 2 percent by the end of the year. CPI inflation is likely to remain below target during 2010 when the negative output gap is forecast to trough, though downward pressure on inflation will be countered by monetary policy support further taking hold. My authorities forecast a stronger rebound in inflation than the Staff and consider the risk of deflation in the CPI measure of inflation to be small given the monetary policy stimulus in 
place and the upward pressure on prices from the continued pass-through of the exchange rate depreciation. As stated in the Staff report, medium-term inflation expectations remain anchored to the inflation target, further mitigating the downside risk of a deflationary scenario.

\section{Fiscal Policy}

Recent economic developments across the globe are having a profound effect on the fiscal positions of many countries and debt is likely to rise significantly in all advanced economies. The UK Government's objectives for fiscal policy in the face of these developments remain unchanged. They are: in the short term to support monetary policy and to allow the automatic stabilisers to help smooth the path of the economy; over the medium term, to ensure sound public finances and a fair impact of spending and taxation within and between generations.

\section{Short- term stimulus}

To support the economy in the short-term, the 2008 Pre-Budget Report announced a timely, targeted and temporary fiscal stimulus package worth around 1 percent of GDP in 2009-10, including a temporary reduction in the rate of VAT to 15 percent and bringing forward $£ 3$ billion of capital spending. The 2009 Budget announced further targeted support to assist recovery including measures to provide temporary support for employment and investment. This amounts to fiscal support worth 4 percent of GDP in 2009-10 from announced measures and the operation of the automatic stabilisers.

\section{Medium- term consolidation}

My authorities fully agree with Staff that in addition to providing short-term stimulus, ensuring the sustainability and credibility of the fiscal position, and setting a path towards consolidation are extremely important. They also share staff's view that the pace of recovery will be important in shaping the consolidation. My authorities are firmly committed to delivering the needed fiscal consolidation and have taken a number of steps to do so beyond the withdrawal of temporary stimulus measures.

First, as welcomed by Staff, the Government has taken a transparent and cautious approach to the fiscal projections. The fiscal forecast assumes that the majority of the deterioration in the fiscal position is structural. It is based on the lower end of the projected GDP forecast range. It uses independently audited assumptions on oil prices and equity prices and the VAT gap. Further, reflecting the principle of transparency, the fiscal forecasts include the high end of a range for a provisional estimate of the net impact of unrealized losses on financial sector interventions, equal to $3 \frac{1}{2}$ percent of GDP.

Second, in light of the current uncertain outlook, the Government has set a temporary fiscal operating rule: to set policies to improve the cyclically-adjusted current budget each year, once the economy emerges from the downturn, so it reaches balance and debt is falling as a proportion of GDP once the global shocks have worked their way through the economy in full. Setting a rule focused on steady improvement in the public finances allows the 
Government flexibility to adjust to unanticipated developments in the economy, while constraining fiscal policy to deliver sound public finances over the medium term.

Third, plans are in place to deliver a sustained fiscal consolidation once the economy emerges from the downturn, including a combination of adjustments to tax and spending. Reflecting uncertainty around prospects for the economy and therefore the public finances, the need to support the economy through the early stages of recovery and the need to deliver sound public finances, the Government has set out steps to ensure they are on a sustainable path. The plans entail a projected improvement in the cyclically-adjusted balance of, on average, over 0.8 percent a year from 2010-11 to 2013-14. Based on cautious fiscal forecasting assumptions, public sector net borrowing is projected to more than halve over 4 years to stand at 5.5 percent of GDP in 2013-14. As a result, net debt is projected to stabilize at 79 percent of GDP, including potential losses on financial sector interventions.

Consistent with the temporary operating rule, these fiscal plans set public finances on a path to achieve cyclically-adjusted current balance by 2017-18 and debt falling as a share of GDP by $2015-16$.

My authorities will continue to do whatever is necessary to ensure sustainable public finances, while continuing to invest in public services and infrastructure.

\section{Monetary Policy}

The UK's current monetary policy framework is well-established and, following its introduction in 1997, delivered over a decade of low and stable inflation. It enshrines a symmetric inflation target that has enabled a decisive response by the Bank of England's Monetary Policy Committee as aggregate demand weakened and the outlook for inflation was revised downwards. Following the credit market dislocation precipitated by the collapse of Lehman Brothers in September 2008, Bank Rate was reduced by 450 basis points in just six months.

In addition, the Government established the Asset Purchase Facility to enable the Bank of England to increase the availability of corporate credit and to provide a framework for the MPC to use asset purchases for monetary policy purposes in January. Since its inception, the Bank of England has announced asset purchases of $£ 125 \mathrm{bn}$. As noted by the Staff, the Bank of England's conventional and unconventional monetary easing has been both 'timely and appropriate'. Of course, ascertaining the effect of this policy will take time, although the sharp drop in gilt yields on announcement provide some indication of the market's view of its likely effectiveness. In line with Staff's recommendations, diversifications of the Bank's asset purchases are currently under active consideration, and consultations have taken place on both a secured commercial paper (SCP) facility and a possible supply chain finance facility.

My authorities agree that the success of the QE policy hinges crucially on the Bank of England maintaining a strict focus on price stability. As Staff note, the design of the QE framework is helpful in this regard. First the March 2009 exchange of letters between the Governor of the Bank of England and the Chancellor establishing the Asset Purchase Facility 
make clear that the MPC retains operational independence, with its remit unchanged. Accordingly, the MPC will decide the timing and size of asset purchases and sales, together with the level of Bank Rate; with the outlook for inflation determining the rate at which the current exceptional monetary stimulus is withdrawn. Second, the operational framework of the Asset Purchase Facility Fund, as a separate legal entity with a separate balance sheet, indemnified by the Treasury, acts to underline the operational independence of the Bank. An indication of the potential inflationary risks of this stimulus is provided by the stability of the latest medium-term inflation expectations surveys (as noted by the Staff in the report). These surveys suggest that expectations continue to be well-anchored to the inflation target.

\section{Financial sector}

Over the past year the UK financial sector has experienced a period of significant distress. In line with their approach to monetary and fiscal policy, the UK authorities have taken wide-ranging action to stabilise the situation in the short term, whilst also focusing on action needed to strengthen the sector over the medium term, and ensuring it can make a strong contribution to delivering economic recovery.

As the crisis heightened last year, my authorities deployed various measures (as listed in Annex I of the Staff Report) to support banks, protect depositors and maintain stability. The recapitalization scheme of October last year, and the introduction of the Asset Protection Scheme (APS) in February this year have been particularly important in stabilising banks, strengthening their capital positions, and helping to foster improved confidence. The APS provides insurance for those assets where there is the greatest degree of uncertainty about their future performance, allowing it to absorb losses and strengthen banks' capital position. The Government has also replaced its preference shares in Lloyds and RBS with new ordinary shares, which has further strengthened their capital positions.

Additionally, to help ensure credit starts to flow into the economy again, lending commitments have been agreed with both Lloyds and RBS. RBS will lend an additional $£ 25$ billion on commercial terms over the 12 months from March 2009 - 29 billion of mortgage lending and $£ 16$ billion of business lending. Lloyds will lend an additional $£ 14$ billion on commercial terms over the 12 months from March $2009-£ 3$ billion of mortgage lending and $£ 11$ billion of business lending. Similar lending commitments have been made in respect of the subsequent 12 months and will be reviewed to ensure they reflect economic circumstances at that time.

Since the Article IV Mission, the vulnerability of the building society sector's limited access to capital has been addressed with the introduction of Profit Participation Deferred Schemes, which were used in the recapitalization of West Bromwich Building Society. Eligibility for

the Government's Recapitalisation and Credit Guarantee Schemes has also been extended to building societies and the Government will shortly consult on measures to enable building societies to offer a floating charge over their assets to the Bank of England or other institution offering financial assistance. The February 2009 Banking Act, which was under development at the time of the last Article IV and which provides a strengthened framework for the resolution of deposit taking institutions has been put into almost immediate use, in the resolution of another building society in March 2009. 
Despite ongoing uncertainties, there are a number of signs that financial conditions are slowly improving, including since the conclusion of the Staff Mission in May. Notably, the latest Bank of England credit conditions survey — published last week — suggests that there has been an increase in credit availability for both households and corporates, reversing the tightening of availability that has been seen for much of the past two years. Banks also expect credit availability to improve further in the next three months for both corporates and households. It is worth noting that much of the fall in lending has come from a reduction in non-bank credit, securities market activity and lending from foreign banks. Over the past few months lending by UK-incorporated banks has continued to expand, albeit at a decelerating rate. Recent data also suggests that house prices are starting to stabilize. Bank funding conditions - as measured by the libor/OIS spread - have continued to improve and are now at their most favourable levels since the collapse of Lehmans. More generally global financial conditions have generally eased and equity prices have continued to recover, including equity prices for UK banks.

Looking ahead, my authorities agree with Staff that further reforms are needed to strengthen the financial sector, in the UK and globally. The supervision of financial institutions is one area where urgent improvement in needed. Lord Turner's report ${ }^{1}$ on this subject provides a thorough analysis of the key areas for reform, the interactions between them, and the implications of regulatory changes. Given the global nature of financial markets and increasing cross-border nature of bank operations those recommendations need to be considered alongside those from the G20 Heads of Government summit, and the reports coming from the EU. The UK Government will also publish a paper about its long-term vision for the financial sector later this week.

The work of Basel Committee to deliver a global framework for promoting stronger bank liquidity buffers, including greater consistency in the treatment of cross-border banking groups is also strongly welcomed by my authorities.

As agreed by all G20 Leaders when they met in Washington DC last November, my authorities are committed to undertaking a further FSAP, and expect the next exercise to be undertaken in 2011.

\section{External spillovers}

As noted by staff, the significant fall in the (real) external value of sterling over the past twelve months has improved the UK current account considerably, mostly reflecting stronger investment income. My authorities remain fully committed to allowing the value of sterling to be determined by market forces and indeed the sterling effective exchange rate has risen by 13 percent since its trough in December 2008. Reflecting this flexible approach, the exchange rate has acted as an effective shock absorber helping smooth the adjustment as the economy contracts.

\footnotetext{
${ }^{1}$ The Turner Review: A regulatory response to the global banking crisis, March 2009
} 
My authorities believe Article IV surveillance needs to strengthen understanding of policy spillovers and international linkages and welcomes such analysis in the report. However, like staff, we think that the hypothetical shock (illustrated in Box 1, page 22) which assesses spillovers from the UK financial system with an illustrative cut in UK banks' foreign lending of 50 percent is a very extreme one, and one which has a very low risk of materialising. At the height of the financial crisis in the fourth quarter of 2008, consolidated foreign claims of UK banks declined by only 14 percent and foreign lending by only 7.9 percent over their levels in September 2008.

\section{Looking ahead}

A year of significant challenge for the UK economy has been supported by wide-ranging and decisive policy action. My authorities approach the year ahead with confidence that is nevertheless tempered with caution given the challenges ahead. International collaboration on the policy response to the crisis as it evolves strengthens the prospect of success. The evolution of the UK economy will continue to be affected by international developments and global as well as domestic policy actions. My authorities therefore stand ready to work with others, and take whatever steps are necessary to restore non-inflationary growth and sustainable public finances. We welcome the IMF's continued policy advice. 